WHC-SP-1163

Revision 0

UC-900

\title{
Safeguards and Security FY 1996 Program Plan WBS 6.6
}

F. D. Lee

Date Published

August 1995

Prepared for the U.S. Department of Energy

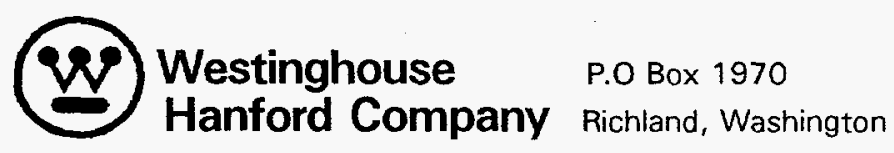

Hanford Operations and Engineering Contractor for the

U.S. Department of Energy under Contract DE-AC06-87RL10930 
LEGAL DISCLAIMER

This report was prepared as an account of work sponsored by an agency of the United States Government. Neither the United States Government nor any agency thereof, nor any of their employees, nor any of their contractors, subcontractors or their employees, makes any warranty, express or implied, or assumes any legal liability or responsibility for the accuracy, completeness, or any third party's use or the results of such use of any information, apparatus, product, or process disclosed, or represents that its use would not infringe privately owned rights. Reference herein to any specific commercial product, process, or service by trade name, trademark, manufacturer, or otherwise, does not necessarily constitute or imply its endorsement, recommendation, or favoring by the United States Government or any agency thereof or its contractors or subcontractors. The views and opinions of authors expressed herein do not necessarily state or reflect those of the United States Government or any agency thereof.

This report has been reproduced from the best available copy. Available in paper copy and microfiche.

Available to the U.S. Department of Energy and its contractors from

Office of Scientific and Technical Information

P.O. Box 62

Oak Ridge, TN 37831

(615) $576-8401$

Available to the public from the U.S. Department of Commerce National Technical Information Service

5285 Port Royal Road

Springfield, VA 22161

(703) $487-4650$

Printed in the United States of America

DISCLM-1.CHP (1-91) 


\section{DISCLAIMER}

Portions of this document may be illegible in electronic image products. Images are produced from the best available original document. 


\section{RELEASE AUTHORIZATION}

Document Number: $\quad W H C-S P-1163$, Rev. 0

Document Title: $\quad$ Safeguards and Security FY 1996 Program Plan WBS 6.6

Release Date: $\quad 8 / 28 / 95$

This document was reviewed following the procedures described in WHC-CM-3-4 and is:

APPROVED FOR PUBLIC RELEASE

WHC Information Release Adminiştration Specialist:

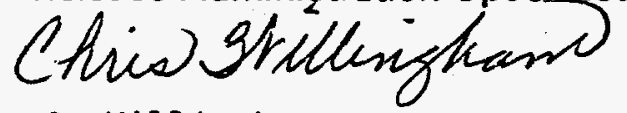

C. Willingham

$8 / 28 / 95$ 
WHC-SP-1163

Safeguards and Security Program Plan Approval Sheet

Safeguards and Security - WBS \#6.6

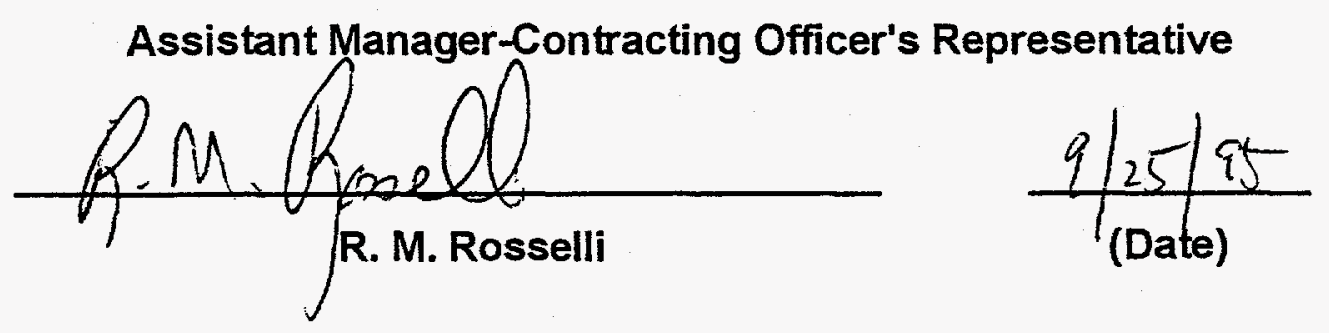

RL Program Manager
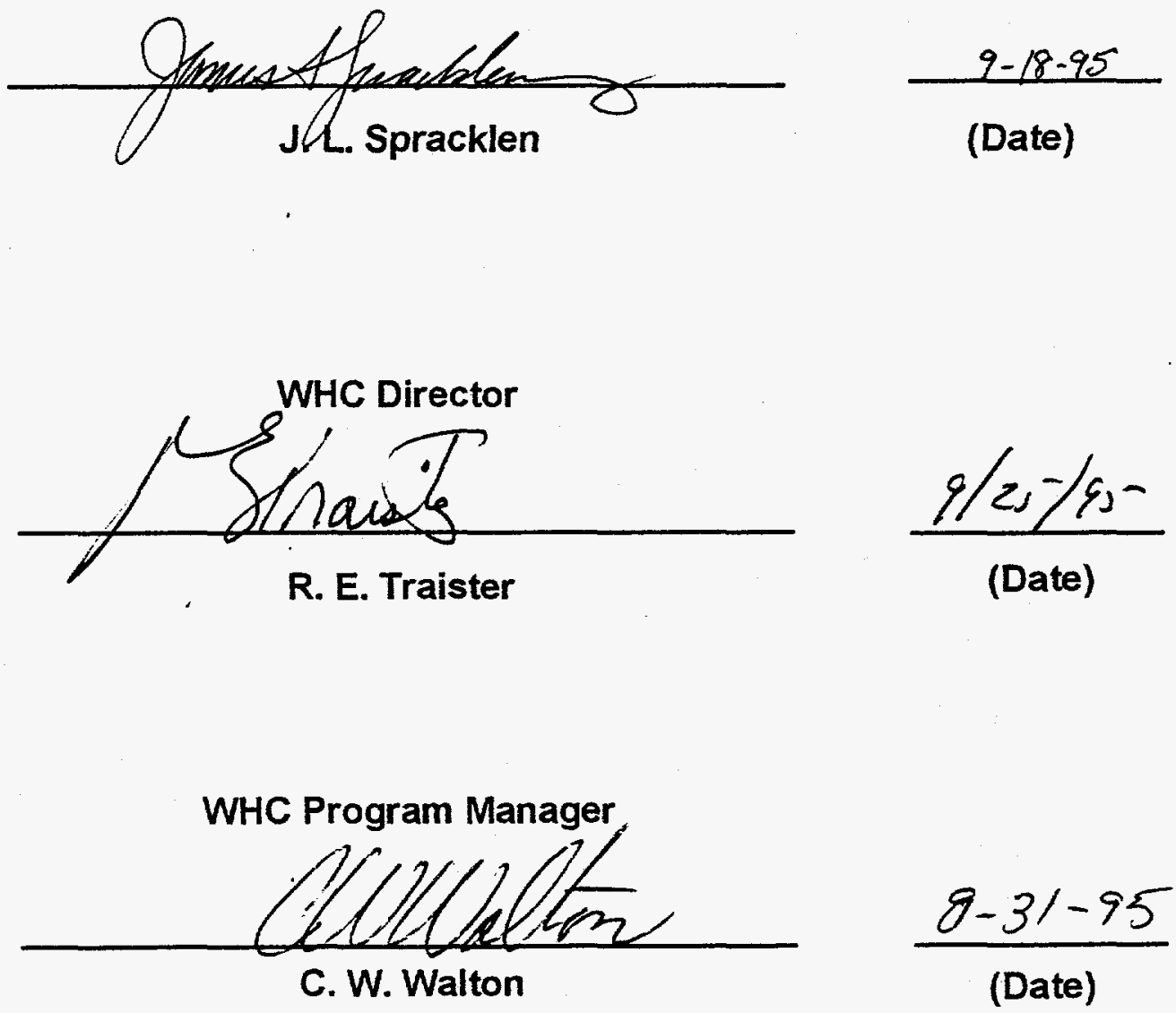

$$
\frac{8-3 /-95}{\text { (Date) }}
$$




\section{CONTENTS}

\section{SAFEGUARDS AND SECURITY \\ FISCAL YEAR 1996 PROGRAM PLAN \\ WBS 6.6}

I. OVERVIEW

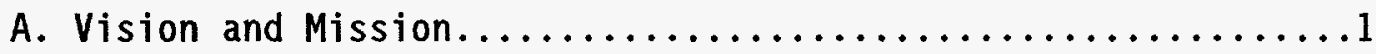
B. Goals and Objectives..............................

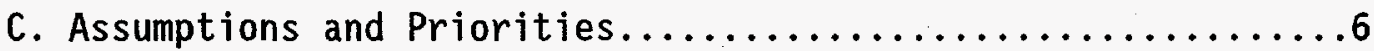
D. Milestones..................................

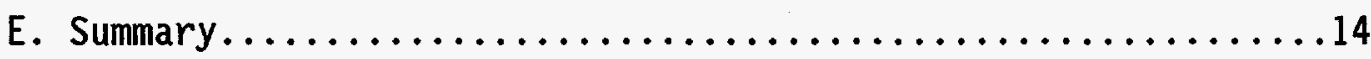

II. SAS WBS DICTIONARY SHEETS 6.6
A. 6.6.1 Department Overhead (DOH) $\ldots \ldots \ldots \ldots \ldots \ldots \ldots \ldots \ldots \ldots \ldots \ldots \ldots \ldots$
B. 6.6.2 General and Administrative (G\&A) .............. 18

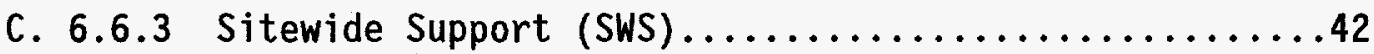
D. 6.6.4 Hanford Patrol SWS........................ 83
E. 6.6 .5 Traffic Safety..........................90
F. 6.6 .6 Locksmith Services.......................95

ADDENDUM 1. Total Staffing Priorities - Indirect Building Blocks 


\section{-}

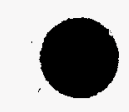

1.A Vision/Mission

Westinghouse Hanford Company

Safeguards and Security

FY 1996

WBS 6.6

Program Plan

August 31,1995

\section{VISION:}

"The Safeguards and Security (SAS) Program is recognized for top quality and innovative services and is sought out as a benchmark."

\section{MISSION:}

"The SAS Program is based upon integrity, competence and innovation in the protection of the public and Hanford resources through:

Outstanding assistance, oversight, education, and counsel to our customers to ensure the protection of the public, Site personnel, assets, and information.

Value-added and cost-effective solutions to Hanford issues.

Risk management techniques to ensure effective asset protection, Site accessibility, and the flexibility to adapt to changing customer needs."

\section{Specific Missions:}

Maintain a standardized program for all Westinghouse (WHC) security functions onsite. Programs shall be consistent with current U.S. Department of Energy (DOE) Orders, Richland Operations Office's Directives and company security policies and procedures.

Physically protect special nuclear material (SNM), classified matter, U.S. Government property, and personnel located within the confines of the Hanford Site and leased facilities.

Develop, maintain, and implement policies and procedures governing the use, control, and accountability of nuclear materials in compliance with DOE Orders. 


\section{Specific Missions (continued):}

Provide guidance, training, and procedures to ensure proper protection is afforded to classified matter and sensitive unclassified information which is processed, stored, transmitted, or discussed throughout WHC.

Provide technical and analytical services which assist DOE in establishing and maintaining uniform and cost-effective safeguards and security programs.

Coordinate and implement new security programs, systems, and upgrades for newly-constructed and existing facilities in order to protect Hanford interests.

Provide protection program planning, evaluation, and validation testing to ensure that levels of protection and risk are appropriate to site security interests that affect the protection of SNM and the health and safety of the public, onsite employees, and the environment.

Develop, implement, and maintain policies and procedures governing the use and operation of government vehicles, roadways, and pedestrian walkways onsite in compliance with DOE Orders and federal regulations. 


\begin{tabular}{|l|c|c|}
\hline $1 . B$ Goals and Objectives & $\begin{array}{c}\text { Westinghouse Hanford Company } \\
\text { Safeguards and Security } \\
\text { WBS 6.6 }\end{array}$ & $\begin{array}{c}\text { FY } 1996 \\
\text { Program Plan } \\
\text { August 31, 1995 }\end{array}$ \\
\hline
\end{tabular}

\section{B.1 Customer Support}

- Support Westinghouse Hanford Company (WHC) Programs in achieving their missions through the utilization of a cost-effective, technically-proficient, and highly-motivated Safeguards and Security (SAS) workforce.

- Aggressively pursue declassification of Hanford documents in conjunction with Richland Operations Office (RL) and Pacific Northwest Laboratories (PNL).

- Maintain a high quality SAS Internal Assessment Program that allows RL to continue approval of a two-year survey schedule.

- Assist Fast Flux Test Facility in relocation of fuel to Plutonium Finishing Plant (PFP) in FY 1996.

- Support PFP in security upgrades required to implement Defense Nuclear Safety Board (DFNSB) (Plutonium Vulnerability) Project 94-1.

- Assist Solid Waste Disposal Program efforts to develop a security concept for the Central Waste Complex.

- Assist K-Basins in developing a measurement plan for sludge.

- Maintain a high-quality performance test program to ensure a highly-effective SAS system and low security risk. 


\begin{tabular}{|l|c|c|}
\hline $1 . B$ Goals and Objectives & $\begin{array}{c}\text { Westinghouse Hanford Company } \\
\text { Safeguards and Security } \\
\text { WBS 6.6 }\end{array}$ & $\begin{array}{c}\text { FY } 1996 \\
\text { Program Plan } \\
\text { August 31, 1995 }\end{array}$ \\
\hline
\end{tabular}

\section{B.2 Production}

- Maintain a $98 \%$ system uptime of the PFP and K-Basins security systems.

- Complete security upgrades for the Solid Waste Program by September, 1996.

- Meet International Atomic Energy Agency requirements with no delay to their schedule.

- Develop security procedures to support Spent Nuclear Fuel Program efforts to relocate K-Basins fuel.

- Gain concurrence for SAS configuration within Canister Storage Facility.

- Acceptance test of Personal Computer-based Alarm Monitoring System (PC-based AMS) at Alarm Monitoring Operations Support System complete by September 30, 1996.

- Remove 100 security keys from operation through use of automated entry systems.

- Complete PFP security system upgrades to support Project 94-1.

- Implement an explosive detection canine program within Hanford Patrol.

- Complete full implementation of the Tactical Training Facility utilizing Simunitions ${ }^{T M}$ for team training.

- Develop a tool that allows line management to evaluate their employee's monthly Internet usage. 


\begin{tabular}{|l|c|c|}
\hline 1.B Goals and Objectives & $\begin{array}{c}\text { Westinghouse Hanford Company } \\
\text { Safeguards and Security } \\
\text { WBS } 6.6\end{array}$ & $\begin{array}{c}\text { FY } 1996 \\
\text { Program Plan } \\
\text { August } 31,1995\end{array}$ \\
\hline
\end{tabular}

\section{B.3 Organization and Management}

- Achieve a perfect safety record in 1996 with no lost work days.

- Achieve a perfect vehicle operation record in 1996 with no vehicle accidents.

- Maintain an effective Safeguards and Security Information Management System (SSIMS) findings, corrective action, and closure program.

- Relocate the Locksmith and Southern Area Maintenance shops to a common facility.

- Substantially increase the amount of direct charge field time of locksmiths, thereby reducing the rate to customers.

- Increase competency of SAS staff through the training and on-the-job experiences via stretch assignments. 


\section{○}

\begin{tabular}{|l|c|c|}
\hline & Westinghouse Hanford Company \\
Safeguards and Security & WBS 6.6 & $\begin{array}{c}\text { FY } 1996 \\
\text { Program Plan } \\
\text { August 31, 1995 }\end{array}$ \\
\hline
\end{tabular}

\section{General Assumptions:}

- Safeguards and Security (SAS) will be responsible for badging all Hanford employees and subcontractor personnel.

- Plutonium Finishing Plant (PFP) will remain a Protected Area and will likely have additional storage of special nuclear material" (SNM) within the yard.

- The K-Basins will remain as a Limited Area under a waiver.

- Fast Flux Test Facility (FFTF) Interim Decay Storage Vessel Row E will remain a Protected Area until such time as the Category I and II material is removed. The protection strategy for hazardous material and Category III and IV SNM will be reevaluated in fiscal year (FY) 1996.

- There will be a reduction of material balance areas (MBAs) with an emphasis on the elimination of legacy waste and excess nuclear material and/or SNM.

- Activities to retrieve solid and liquid materials from past-practice waste sites may unearth classified and/or SNM material that will require additional protection for an undetermined, interim period.

- Pacific Northwest Laboratory Category III SNM locations will continue to be reduced.

- There has been no provision made for Hanford Patrol overtime in support of FFTF shipments in FY 1996. Change control will be employed as the shipment plans are completed.

- The movement of all FFTF Category I and II SNM will be complete by August 31, 1996. Movement of the Category I SNM will not reduce the material control and accountability funding requirements from FFTF. 


\section{C Assumptions/Priorities}

Westinghouse Hanford Company Safeguards and Security WBS 6.6
FY 1996

Program Plan August 31,1995

\section{General Assumptions (continued):}

- Property Protection Areas and Limited Areas will be maintained as required.

- A comprehensive readiness review will be conducted at Hanford in FY 1996.

- U.S. and foreign visitors to Hanford facilities will continue to increase and enhanced efforts will be required to avoid unauthorized access to classified and sensitive information.

- Implementation of the U.S. Department of Energy (DOE) Integrated Safeguards and Security Systems/Electronic Transfer (DISS/ET) system will require incremental funding in FY 1996.

- Based on international agreements, additional SNM may be placed under International Atomic Energy Agency (IAEA) accountability, and Hanford will continue to support the monthly IAEA inspections. However, program costs associated with IAEA inspection activities are not SAS costs and are not reflected within this budget estimate.

- There will be a continued need to evaluate programs and information to determine their sensitivity based on changing national military/economic priorities.

- Westinghouse Hanford Company (WHC) will provide badging and protective force services for the Environmental Restoration contractor Bechtel Hanford, Inc. (BHI). The Environmental Restoration program will not require additional protective force positions.

- There will be no significant additions or reductions to SNM inventories due to receipts or removals.

- Patrol will maintain a Random Search Team and four Site Rovers for Site surveillance.

- Patrol will maintain a Special Response Team at a seven-member, 24-hour basis. 


\section{C Assumptions/Priorities}

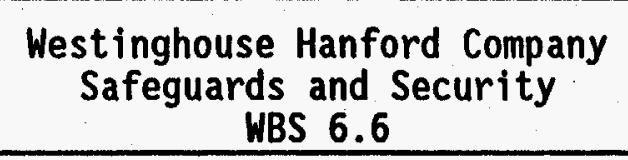

FY 1996

Program Plan August 31,1995

\section{General Assumptions (continued):}

- Benton County Sheriff's Office (BCSO) is an Richland Operations Office (RL) controlled contract. It is not included in the WHC SAS Program Plan.

- The BCSO and City of Richland Police Department will perform all state and local law enforcement functions.

- Security investigations will be conducted only for incidents defined as significant by RL. Event trending and analysis. will be performed to identify significant events/trends.

- The current nuclear materials accounting and control system will be maintained until the DOE sponsored Local Area Network Material Accountability System (LANMAS) is available and modified for Hanford Site specific requirements in FY 1997.

- Plans to integrate the Patrol Operations Center activities into a Site Central Dispatch Center will continue. Cost and headcount for the SAS function at the dispatch center will remain in the SAS planning. The Site Central Dispatch Center is planned to be operational October, 1996.

- There will be increased emphasis on the Counterintelligence and the Operations Security Program as a result of treaty inspections, IAEA, foreign national visitor assignments, and increased espionage threats.

- Classified work will continue to be consolidated to a minimum number of Limited Areas.

- Sensitive unclassified work will require identification and consolidation to the lowest practical number of Site locations. 


\begin{tabular}{|l|c|c|}
\hline I.C Assumptions/Priorities & $\begin{array}{c}\text { Westinghouse Hanford Company } \\
\text { Safeguards and Security } \\
\text { WBS 6.6 }\end{array}$ & $\begin{array}{c}\text { FY } 1996 \\
\text { Program Plan } \\
\text { August 31, 1995 }\end{array}$ \\
\hline
\end{tabular}

\section{General Assumptions (continued):}

- Protection strategies may be modified at certain Hanford Site facilities (such as Tank Farms, K-Basins, and B Plant) based on the results of vulnerability assessment (VA)/Risk sabotage analyses of hazardous material interests. These potential changes are not considered in program budgets.

- Declassification is an incremental cost through completion, estimated at Fr 2000.

- Hanford Patrol may conduct one basic training class for new recruits in FY 1996.

- SAS will participate, as required, in achieving a Site goal to remove and consolidate excess nuclear materials from the 300 Area to the 200 Areas.

- SAS will interact with Human Resources and others to ensure development/operations of an effective policy on violence in the workplace.

- SAS will continue to outsource internal surveys of its SAS major program elements.

- U.S. Department of Energy Headquarters Threat Guidance and procedures may change based on world events; however, associated costs with any increase in current security policy will be considered as new work scope. 


\begin{tabular}{|l|c|c|}
\hline 1.C Assumptions/Priorities & $\begin{array}{c}\text { Westinghouse Hanford Company } \\
\text { Safeguards and Security } \\
\text { WBS 6.6 }\end{array}$ & $\begin{array}{c}\text { FY } 1996 \\
\text { Program Plan } \\
\text { August 31, 1995 }\end{array}$ \\
\hline
\end{tabular}

\section{Priorities:}

I. Protection of SNM

- Support FFTF Fuel transfer (CAT I fuel) to PFP

- RAD/TOX VA/Risk Analyses

- PFP and K-Basins VA/Risk Analyses and upgrades

- IAEA requirements

- Removal of excess nuclear material from 300 Area

- Relocation of SNM waste

- PFP security system upgrades

- Consolidation and reduction of SNM locations

- Protection strategies for retrieved waste

II. Requirements

- Sensitive facilities and information identification/consolidation

- Declassification

- Maintain current VA/Risk Analysis of foreign visits

- Impacts of treaties/bilateral agreements

- Strategy to resolve RLID elimination

- Complete training Order implementation

- Implement the DISS/ET and follow-on upgrades

- 5630.16A Performance Test Order

- Unclassified computer security OPSEC concerns

- Openness initiative 


\section{Priorities (continued):}

III. Better Business Practices

- Streamlining of foreign visits and assignments process

- Organizational realignment impacts

- Protection Program viability

- Reduction of classified holdings

- Complete consolidation of clearance processing

- Security awareness

- Stable forecast/Patrol staffing needs

- Personnel Security Clearance Record (PSCR)+ completion

- Long Distance Learning expansion

- Implementation of the disposable temporary and visitor badges

- Integrated security posture

- Consolidated Dispatch Center

- Enhance internal survey/self-assessment process

- Integrate Site technical standards

- Violence in the workplace issues

- Identify badge requirements south of the barricade/public access areas

- Return commissions to Patrol

- Clearance reductions

- Smart Cards - Integration of smart cards and proximity cards

- Utilization of technologies

- BHI interface

- IAEA preparation 


\begin{tabular}{|c|c|c|c|c|}
\hline WBS & No. & Indirect Milestone & Due Date & Deliverable \\
\hline 6.6 .2 .1 & $96-01$ & $\begin{array}{l}\text { Complete and implement the WHC Operations Security Plan } \\
\text { for fiscal year 1996. This plan will describe those } \\
\text { goals and objectives to meet requirements established by } \\
\text { RL and DOE Order } 5639.7 \text {. }\end{array}$ & $10 / 31 / 95$ & Plan \\
\hline 6.6 .3 .4 & $96-02$ & $\begin{array}{l}\text { Complete the } 1995 \text { Hanford Site Safeguards and Security } \\
\text { Plan - Part I Safeguards and Security Management Report. }\end{array}$ & $11 / 30 / 95$ & Plan \\
\hline 6.6 .3 .12 & $96-03$ & $\begin{array}{l}\text { Complete and implement a computerized key control } \\
\text { management program for Building Administrators/Key } \\
\text { Custodians. }\end{array}$ & $12 / 31 / 95$ & Program \\
\hline 6.6 .3 .12 & $96-04$ & $\begin{array}{l}\text { Complete and implement a computerized management control } \\
\text { program for the 0mnilock access control systems. }\end{array}$ & $12 / 31 / 95$ & Program \\
\hline 6.6 .4 & $96-05$ & $\begin{array}{l}\text { Complete Emergency Medical Dispatcher Training for all } \\
\text { Patrol Operations Center personnel. }\end{array}$ & $01 / 31 / 96$ & $\begin{array}{l}\text { Letter of } \\
\text { Completion }\end{array}$ \\
\hline 6.6 .4 & $96-06$ & $\begin{array}{l}\text { Implement Simunitions }{ }^{T M} \text { Training Program for Security } \\
\text { Police Officer (SP0) IIIs. }\end{array}$ & $02 / 01 / 96$ & $\begin{array}{l}\text { Letter of } \\
\text { Completion }\end{array}$ \\
\hline 6.6 .3 .1 & $96-07$ & Submit revised Hanford Site SAS Training Program Plan. & $04 / 30 / 96$ & Plan \\
\hline 6.6 .2 .4 & $96-08$ & $\begin{array}{l}\text { Develop a CRIME STOPPER prototype program for the } \\
\text { Hanford Site. (Implementation will be done by BCSO). }\end{array}$ & $05 / 31 / 96$ & Program \\
\hline 6.6 .3 .1 & $96-09$ & Complete Fiber Optic Sensor Implementation Plan. & $06 / 01 / 96$ & Plan \\
\hline 6.6 .4 & $96-10$ & Implement a Canine Explosive Detector Program. & $06 / 01 / 96$ & Program \\
\hline 6.6 .2 .1 & $96-11$ & Complete the WHC Computer Protection Plan for FY 1996. & $06 / 30 / 96$ & Plan \\
\hline 6.6 .3 .1 & $96-12$ & $\begin{array}{l}\text { Submit SAS Distance Learning Resource Utilization } \\
\text { Implementation Plan. }\end{array}$ & 07/01/96 & Plan \\
\hline
\end{tabular}




\begin{tabular}{|c|c|c|c|c|}
\hline WBS & No. & Indirect Milestone & Due Date & Deliverable \\
\hline 6.6 .3 .1 & $96-13$ & $\begin{array}{l}\text { Complete Spread Spectrum Communication Implementation } \\
\text { Plan. }\end{array}$ & 08/01/96 & Plan \\
\hline 6.6 .3 .2 & $96-14$ & Complete internal surveys for FY 1996. & $08 / 31 / 96$ & $\begin{array}{l}\text { Letter of } \\
\text { Completion }\end{array}$ \\
\hline 6.6 .4 & $96-15$ & $\begin{array}{l}\text { A11 Special Response Team Lieutenants complete Central } \\
\text { Training Academy's Firearm Instructor Certification. }\end{array}$ & $09 / 30 / 96$ & $\begin{array}{l}\text { Letter of } \\
\text { Completion }\end{array}$ \\
\hline 6.6 .4 & $96-16$ & Complete 48 Limited Scope Performance Test exercises. & $09 / 30 / 96$ & Report \\
\hline 6.6 .3 .2 & $96-17$ & $\begin{array}{l}\text { Complete Performance Tests for Category I \& II } \\
\text { facilities for FY } 1996 .\end{array}$ & 09/30/96 & Report \\
\hline 6.6 .2 .2 & $96-18$ & $\begin{array}{l}\text { Conduct quarterly internal self-evaluations of the self- } \\
\text { expiring and building-specific badging procedures of } \\
\text { WHC, BCSR, and ICF KH. }\end{array}$ & Quarterly & $\begin{array}{l}\text { Quarterly } \\
\text { Report }\end{array}$ \\
\hline 6.6 .3 .3 & $96-19$ & Complete six VAs/Risk Analyses & $\begin{array}{l}\text { Per } \\
\text { Schedule }\end{array}$ & Report \\
\hline
\end{tabular}




\begin{tabular}{|l|c|c|}
\hline Indirect Summary & $\begin{array}{c}\text { Westinghouse Hanford Company } \\
\text { Safeguards and Security } \\
\text { WBS 6.6 }\end{array}$ & $\begin{array}{c}\text { FY 1996 } \\
\text { Program Plan } \\
\text { August 31, 1995 }\end{array}$ \\
\hline
\end{tabular}

\section{FY 1995 (FYSF)}

\section{Total FY 1996}

\begin{tabular}{|c|c|c|c|c|c|}
\hline SMS & Funding Source & FTE & $\$$ In 000's & FTE & $\$ \ln 000$ 's \\
\hline 6.6 .1 & Department Overhead (DOH) & 19.8 & 7,695 & 20.6 & 7,711 \\
\hline 6.6 .2 & General and Administrative (G\&A) & 37.9 & 3,173 & 25.6 & 2,134 \\
\hline 6.6.3 & Sitewide Support (SWS) & 34.9 & 3,068 & 31.4 & 2,886 \\
\hline 6.6 .4 & Sitewide Support (SWS) Patrol & 97.9 & 8,407 & 97.4 & 7,762 \\
\hline 6.6 .5 & Traffic Safety & 5.0 & 421 & 2.0 & 198 \\
\hline 6.6 .6 & Locksmiths & 7.2 & 852 & 7.4 & 737 \\
\hline & TOTAL: & 202.7 & 23,616 & 184.4 & 21,428 \\
\hline
\end{tabular}




\begin{tabular}{|c|c|c|c|c|c|}
\hline \multicolumn{2}{|c|}{$\begin{array}{l}\text { 2.A.1 } \\
\text { Work Breakdown Structure and } \\
\text { Responsibility Assignment Matrix }\end{array}$} & \multicolumn{2}{|r|}{$\begin{array}{c}\text { Westinghouse Hanford Company } \\
\text { Safeguards and Security } \\
\text { WBS } 6.6\end{array}$} & \multicolumn{2}{|c|}{$\begin{array}{c}\text { FY } 1996 \\
\text { Program Plan } \\
\text { August } 31, \quad 1995 \\
\end{array}$} \\
\hline Program Element & Activity & Cost Account & Title & $\begin{array}{l}\text { Responsible } \\
\text { Manager }\end{array}$ & $\begin{array}{l}\text { Responsible } \\
\text { Organization } \\
\end{array}$ \\
\hline 6.6 .1 & 6.6 .1 & $\mathrm{DOH}$ & Department Overhead & C. W. Walton & $8 P 000$ \\
\hline 6.6 .2 & 6.6 .2 .1 & G\&A & Information Security & D. E. Palmer & $8 P 400$ \\
\hline 6.6 .2 & 6.6 .2 .2 & G\&A & Access Control/Personnel Security & W. J. Hawkins & $8 P 300$ \\
\hline 6.6 .2 & 6.6 .2 .3 & G\&A & Safeguards and Security G\&A IRM Support & W. J. Hawkins & $8 \mathrm{P} 300$ \\
\hline 6.6 .2 & 6.6 .2 .4 & G\&A & Security Investigations & V. G. Heiman & $8 \mathrm{P} 200$ \\
\hline 6.6 .2 & 6.6 .2 .5 & G\&A & Security Education & V. G. Heiman & $8 \mathrm{P} 200$ \\
\hline 6.6 .3 & $6 \cdot 6.3 .1$ & SWS & Technical Support Services & D. E. Palmer & $8 P 400$ \\
\hline 6.6 .3 & 6.6 .3 .2 & SWS & Performance Testing and Surveys & C. J. Udell & $8 P 600$ \\
\hline 6.6 .3 & 6.6 .3 .3 & SWS & Radiological/Toxicological VA Analysis & C. J. Udell & $8 P 600$ \\
\hline 6.6 .3 & 6.6 .3 .4 & SWS & Site Safeguards and Security Plan & C. J. Ude11 & $8 P 600$ \\
\hline 6.6 .3 & 6.6 .3 .5 & SWS & Threat Evaluation & C. J. Udell & $8 P 600$ \\
\hline 6.6 .3 & 6.6 .3 .6 & SWS & $\begin{array}{l}\text { Northern Area Industrial Security } \\
\text { Engineering }\end{array}$ & V. G. Heiman & $8 P 200$ \\
\hline 6.6 .3 & 6.6 .3 .7 & SWS & Northern operations Industrial Security & V. G. Heiman & $8 \mathrm{P} 200$ \\
\hline 6.6 .3 & 6.6 .3 .8 & SWS & $\begin{array}{l}\text { Northern Area Industrial Security IRM } \\
\text { Support }\end{array}$ & V. G. Heiman & $8 P 200$ \\
\hline 6.6 .3 & 6.6 .3 .9 & SWS & Badging Operations & W. J. Hawkins & $8 \mathrm{P} 300$ \\
\hline 6.6 .3 & 6.6 .3 .10 & SWS & $\begin{array}{l}\text { Southern Area Industrial Security } \\
\text { (Security Maint.) }\end{array}$ & D. J. Haskins & $8 P 700$ \\
\hline 6.6 .3 & 6.6 .3 .11 & SWS & $\begin{array}{l}\text { Southern Area Industrial Security } \\
\text { (Physical Security) }\end{array}$ & D. J. Haskins & $8 P 700$ \\
\hline 6.6 .3 & 6.6 .3 .12 & SWS & Industrial Security Administration & D. J. Haskins & $8 P 700$ \\
\hline
\end{tabular}




\begin{tabular}{||c|c|c|c|c|c|}
\hline \hline $\begin{array}{l}\text { 2.A.1 } \\
\text { Work Breakdown Structure and } \\
\text { Responsibility Assignment Matrix }\end{array}$ & \multicolumn{2}{|c|}{$\begin{array}{c}\text { Westinghouse Hanford Company } \\
\text { Safeguards and Security } \\
\text { WBS 6.6 }\end{array}$} & \multicolumn{2}{c|}{$\begin{array}{c}\text { FY 1996 } \\
\text { Program Plan } \\
\text { August 31, } \\
\text { 1995 }\end{array}$} \\
\hline Program Element & Activity & Cost Account & \multicolumn{1}{|c|}{ Title } & $\begin{array}{c}\text { Responsible } \\
\text { Manager }\end{array}$ & $\begin{array}{c}\text { Responsible } \\
\text { Organization }\end{array}$ \\
\hline 6.6 .4 & 6.6 .4 & SWS & Sitewide Support (SWS) Patrol & $\begin{array}{c}\text { G. P. } \\
\text { McDowe11 }\end{array}$ & $8 P 500$ \\
\hline 6.6 .5 & 6.6 .5 & G\&A & Traffic Safety & C. W. Walton & 8 P000 \\
\hline 6.6 .6 & 6.6 .6 & $\begin{array}{c}\text { Direct } \\
\text { Charging }\end{array}$ & $\begin{array}{l}\text { Locksmiths Direct Charging Service } \\
\text { Center }\end{array}$ & D. J. Haskins & 8 P700 \\
\hline
\end{tabular}

Note: Direct workscope is not included in WBS 6.6 (SAS) but is controlled through the various program plans for facilities requiring SAS services. Summary level workscope and budget projections for direct workscope will be provided as an addendum to this document in order for a total SAS cost baseline. Any change control required in direct work in FY 1996 will be processed through program offices for approval while SAS sitewide activities will be managed for change control through RL SAS. 


\begin{tabular}{|c|c|c|}
\hline & $\begin{array}{c}\text { Westinghouse Hanford Company } \\
\text { Safeguards and Security } \\
\text { WBS } 6.6\end{array}$ & $\begin{array}{c}\text { FY 1996 } \\
\text { Program Plan } \\
\text { August 31, 1995 }\end{array}$ \\
\hline
\end{tabular}

Total FY 1996

\begin{tabular}{|c|c|c|c|}
\hline SMS & Department Overhead WBS/SMS 6.6.1 & FTE & $\$$ In 000's \\
\hline 6.6 .1 & Department Overhead (DOH) & 20.6 & 7,711 \\
\hline
\end{tabular}




\begin{tabular}{|c|c|c|c|c|c|c|c|c|c|}
\hline $\begin{array}{l}\text { Work } \\
\text { Breakdown } \\
\text { Structure } \\
\text { Dictionary }\end{array}$ & \multicolumn{6}{|c|}{$\begin{array}{c}\text { Westinghouse Hanford Company } \\
\text { Safeguards and Security } \\
\text { Part I - Summary } \\
\text { (Dollars in } 000 \text { 's) }\end{array}$} & \multicolumn{3}{|c|}{$\begin{array}{l}\text { FY } 1996 \\
\text { Indirect } \\
\text { Program Plan } \\
\text { Rev. \# } 0\end{array}$} \\
\hline $\begin{array}{c}\text { Cost Account Number } \\
1 \mathrm{~J} 8 \mathrm{P} \\
\end{array}$ & \multicolumn{6}{|c|}{ Safeguards and Security Department Overhead } & \multicolumn{3}{|c|}{$\begin{array}{l}\text { Proposed Rate: 26.5\% } \\
\text { (Rated Service Pool Only) }\end{array}$} \\
\hline $\begin{array}{r}\text { SMS WBS Number } \\
6.6 .1\end{array}$ & \multicolumn{6}{|c|}{ Safeguards and Security Department Overhead } & \multicolumn{3}{|c|}{ Funding Source: } \\
\hline RL SMS Program Manger & \multicolumn{6}{|c|}{ J. L. Spracklen } & \multicolumn{3}{|l|}{ SWS } \\
\hline Cost Account Manager & \multicolumn{6}{|l|}{ C.W. Walton } & \multicolumn{3}{|l|}{ OST } \\
\hline WHC SMS Program Manager & \multicolumn{6}{|l|}{ C.W. Walton } & \multicolumn{3}{|l|}{ DOH } \\
\hline Financial Manager & \multicolumn{6}{|l|}{ F.D. Le日 } & \multicolumn{3}{|l|}{ MGT PRO } \\
\hline Responsible Analyst & \multicolumn{6}{|l|}{ L.V. Jones } & \multicolumn{3}{|l|}{ POOL } \\
\hline & \multicolumn{3}{|c|}{$\begin{array}{l}\text { FY } 1996 \text { Approved Funding } \\
\text { Full-Time Equivalents (FTEs) }\end{array}$} & \multicolumn{3}{|c|}{$\begin{array}{l}\text { FY } 1996 \text { Unfunded } \\
\text { Full-Time Equivalents (FTEs) }\end{array}$} & \multicolumn{3}{|c|}{$\begin{array}{c}\text { FY } 1996 \text { Baseline } \\
\text { Full-Time Equivalents (FTEs) }\end{array}$} \\
\hline TYPE OF FTE & Exempt & Non-Exempt & Bargaining & Exempt & Non-Exempt & Bargaining & Exempt & Non-Exempt & Bargaining \\
\hline Organizational & 12.3 & 5.8 & 0.8 & & & & 12.3 & 5.8 & 0.8 \\
\hline Support & 1.0 & & 0.7 & & & & 1.0 & 0.0 & 0.7 \\
\hline TOTALFTES & 13.3 & 5.8 & 1.5 & 0.0 & 0.0 & 0.0 & 13.3 & 5.8 & 1.5 \\
\hline COST ELEMENTS & \multicolumn{3}{|c|}{ FY 1996 Approved Funding'Budget } & \multicolumn{3}{|c|}{ FY 1996 Unfunded Budget } & \multicolumn{3}{|c|}{ FY 1996 Baseline Budget } \\
\hline Labor - Regular & & & 1,123 & & & & & & 1,123 \\
\hline Labor - Overtime & & & & & & & & & 0 \\
\hline 0 Total Labor & & & 1,123 & & & 0 & & & 1,123 \\
\hline 1 Materials & & & 504 & & & & & & 504 \\
\hline 2 Purchased Services & & & 474 & & & & & & 474 \\
\hline 3 Other Hanford & & & 70 & & & & & & 70 \\
\hline Subtotal Originated Costs. & & & 2,171 & & & 0 & & & 2,171 \\
\hline 4 Site Services & & & 3,132 & & & & & & 3,132 \\
\hline 5 Internal Charges & & & 1,537 & & & & & & 1,537 \\
\hline 6 IRM Support & & & 871 . & & & & & & 871 \\
\hline 7 Overheads & & & & & & & & & 0 \\
\hline 8 Revenue & & & & & 2: & & & & 0 \\
\hline TOTAL DOLLARS & & & 7,711 . & & & 0 & & & 7,711 \\
\hline $\begin{array}{l}\text { SIGNATURES } \\
\text { Financial Analyst: }\end{array}$ & & & Date: & & BASELINE AP & PROVAL & & & \\
\hline
\end{tabular}




\begin{tabular}{|c|c|c|c|c|c|}
\hline \multirow{6}{*}{$\begin{array}{l}\text { Work } \\
\text { Breakdown } \\
\text { Structure } \\
\text { Dictionary }\end{array}$} & \multirow{6}{*}{\multicolumn{3}{|c|}{$\begin{array}{c}\text { Westinghouse Hanford Company } \\
\text { Safeguards and Security } \\
\text { Part I - Summary } \\
\text { (Dollars in } 000^{\prime} \text { s) }\end{array}$}} & \multirow{8}{*}{$\begin{array}{l}\text { FY } 1996 \text { SSPP } \\
\text { Rev. \# } 0\end{array}$} & Funding Source: \\
\hline & & & & & G\&A \\
\hline & & & & & sWS \\
\hline & & & & & OST \\
\hline & & & & & $\mathrm{DOH}$ \\
\hline & & & & & MGT PAO \\
\hline Cost Account & \multirow{2}{*}{\multicolumn{3}{|c|}{$\begin{array}{l}\text { Cost Account Title } \\
\text { Safeguards and Security Department Overhead }\end{array}$}} & & POOL \\
\hline $1 \mathrm{N8B}$ & & & & & DIRECT \\
\hline $\begin{array}{ll}\text { SMS WBS } & 6.6 .1 \\
\end{array}$ & \multicolumn{3}{|c|}{ Safeguards and Security Department Overhead } & \multirow{2}{*}{\multicolumn{2}{|c|}{$\begin{array}{c}\text { Annualized Rate } \\
\text { (For Organizational Overhead and } \\
\text { Rated Service Pool Use Only) }\end{array}$}} \\
\hline CAM Review/Approval & \multicolumn{2}{|r|}{ C.W. Walton } & Date & & \\
\hline \multicolumn{2}{|l|}{ SMS Program Manager Review/Approval } & C.W. Walton & Date & FY 1995 Rate & FY 1996 Rate \\
\hline \multicolumn{2}{|l|}{ Financial Manager Review/Approval } & F.D. Lee & Date & $36.6 \%$ & $26.5 \%$ \\
\hline \multicolumn{2}{|l|}{ Responsible Analyst } & L.V. Jones & Date & FY 1996 Target Rate & \multirow[t]{2}{*}{ FY 1996 Approved Rate } \\
\hline OSBRB Review/Approval & & & Date & $26.5 \%$ & \\
\hline & FY19 & & & FY 1996 & \\
\hline FULL-TIME EQUIVALENTS (FTES) & Budget & $\begin{array}{l}\text { Fiscal Year Spending } \\
\text { Forecast (FYSF) }\end{array}$ & Target & Request & $\begin{array}{l}\text { Approved } \\
\text { Baseline }\end{array}$ \\
\hline Organizational - Exempt & 11.5 & & & 12.3 & \\
\hline . Organizational - Nonexempt & 7.6 & & & 5.8 & \\
\hline . Organizational - Bargaining & 1.1 & & & 0.8 & \\
\hline Total Organizational FTEs & 20.2 & & & 18.9 & \\
\hline Support FTEs & & & & 1.7 & \\
\hline TOTAL FTES & 20.2 & & & 20.6 & \\
\hline COST ELEMENTS & & & & & \\
\hline . Labor - Regular & 1,086 & & & 1123 & \\
\hline . Labor - Overtime & 14 & & & 0 & \\
\hline 0 Total Labor & 1,100 & & & 1,123 & \\
\hline 1 Materials & 505 & & & 504 & \\
\hline 2 Purchased Senvices & 474 & & & 474 & \\
\hline 3 Other Hanford & 70 & & & 70 & \\
\hline 4 Site Services & 3,145 & & & 3132 & \\
\hline 5 Internal Charges & 1,551 & & & 1537 & \\
\hline 6 IRM Support & 899 & & & 871 & \\
\hline \begin{tabular}{|l}
7 Overheads \\
\end{tabular} & & & & & \\
\hline 8 Revenue & & & & & \\
\hline TOTALDOLLARS & 7,744 & 7,695 & & 7,711 & \\
\hline
\end{tabular}

* FY 96 Budget Request includes 2 FTEs for financial support and does not reflect final assessments. 
COST ACCOUNT

\begin{tabular}{|l|c}
\hline $\begin{array}{l}\text { Work Breakdown } \\
\text { Structure } \\
\text { Dictionary }\end{array}$ & Westinghouse Hanford Company \\
Safeguards and Security \\
Part II - Element Definition
\end{tabular}

FY 1996 SSPP

Part II - Element Definition

Revision \#0

WBS ELEMENT CODE: 6.6 .1
ELEMENT TASK DESCRIPTION
FUNDING SOURCE: Department Overhead (DOH)
TASK DESCRIPTION:
This task provides department overhead costs for the Safeguards and Security (SAS) organization to support direct-funded
exempt, nonexempt, and bargaining unit personnel. The support includes building administration, performance measurements
vehicle and equipment management, policy and procedure development, training, secretarial support, and budget
programming/planning.
Elimination of this task would cut essential overhead support for the Plutonium Finishing Plant, Spent Nuclear Fuel,
Transition Projects, international agreements, and Fast Flux Test Facility. Funding would be eliminated for training,
technical exchanges, and administration. SAS would be unable to respond to U.S. Department of Energy (DOE), Richland
Operations Office's requests for information, performance ratings, Sitte Management System reporting, corrective action
plans, reviews for compliance, support for DOE workshops, and overall management of critical security programs.

\section{ASSUMPTIONS:}

None identified.

\section{MILESTONES:}

None identified.

DELIVERABLES:

None identified.

O: :


General \& Administrative (G\&A) Summary
Westinghouse Hanford Company Safeguards and Security WBS 6.6
FY 1996

Program Plan August 31, 1995

\section{Total FY 1996}

\begin{tabular}{|c||c|c|c||}
\hline \hline SMS & \multicolumn{1}{|c|}{ General and Administrative WBS/SMS 6.6.2 } & FTE & 9. \\
\hline 6.6 .2 .1 & Information Security & 11.3 & 807 \\
\hline 6.6 .2 .2 & Access Control/Personnel Security & 817 \\
\hline 6.6 .2 .3 & Safeguards and Security G\&A IRM Support & 85 \\
\hline 6.6 .2 .4 & Security Investigations & 2.5 & 214 \\
\hline 6.6 .2 .5 & Security Education & 211 \\
\hline \hline & Elimination of cross charging & & 2. \\
\hline & TOTAL: & $1443)$ & \\
\hline
\end{tabular}




\begin{tabular}{|c|c|c|c|c|c|c|c|c|c|}
\hline $\begin{array}{l}\text { Work } \\
\text { Breakdown } \\
\text { Structure } \\
\text { Dictionary }\end{array}$ & \multicolumn{6}{|c|}{$\begin{array}{c}\text { Westinghouse Hanford Company } \\
\text { Safeguards and Security } \\
\text { Part I - Summary } \\
\text { (Dollars in } 000 \text { 's) }\end{array}$} & \multicolumn{3}{|c|}{$\begin{array}{l}\text { FY } 1996 \\
\text { Indirect } \\
\text { Program Plan } \\
\text { Rev. \# } 0\end{array}$} \\
\hline $\begin{array}{r}\text { Cost Account Number } \\
1 \text { MDD3X } \\
\end{array}$ & \multicolumn{6}{|c|}{ G\&A Safeguards and Security } & \multicolumn{3}{|c|}{$\begin{array}{l}\text { Proposed Rate: } \\
\text { (Rated Service Pool Only) }\end{array}$} \\
\hline $\begin{array}{r}\text { SMS WBS Number } \\
6.6 .2 \\
\end{array}$ & \multicolumn{6}{|c|}{ G\&A Safeguards and Security } & \multicolumn{3}{|c|}{ Funding Source: } \\
\hline RL SMS Program Manger & \multicolumn{6}{|l|}{ J. L. Spracklen } & \multicolumn{3}{|l|}{ sws } \\
\hline Cost Account Manager & \multicolumn{6}{|l|}{ C.W. Walton } & \multicolumn{3}{|l|}{ OST } \\
\hline WHC SMS Program Manager & \multicolumn{6}{|l|}{ C.W. Walton } & \multicolumn{3}{|l|}{$\mathrm{DOH}$} \\
\hline Financial Manager & \multicolumn{6}{|l|}{ F.D. Lee } & \multicolumn{3}{|l|}{ MGT PRO } \\
\hline Responsible Analyst & \multicolumn{6}{|l|}{ L.V. Jones } & \multicolumn{3}{|l|}{ POOL } \\
\hline & \multicolumn{3}{|c|}{$\begin{array}{c}\text { FY } 1996 \text { Approved Funding } \\
\text { Full-Time Equivalents (FTEs) }\end{array}$} & \multicolumn{3}{|c|}{$\begin{array}{l}\text { FY } 1996 \text { Unfunded } \\
\text { Full-Time Equivalents (FTEs) }\end{array}$} & \multicolumn{3}{|c|}{$\begin{array}{c}\text { FY } 1996 \text { Baseline } \\
\text { Full-Time Equivalents (FTEs) }\end{array}$} \\
\hline TYPE OF FTE & Exempt & Non-Exempt & Bargaining & Exempt & Non-Exempt & Bargaining & Exempt & Non-Exempt & Bargaining \\
\hline Organizational & 17.0 & 7.5 & 0.3 & & & & 17.0 & 7.5 & 0.3 \\
\hline Support & 0.8 & & & & & & 0.8 & 0.0 & 0.0 \\
\hline TOTALFTES & 17.8 & 7.5 & 0.3 & 0.0 & 0.0 & 0.0 & 17.8 & 7.5 & 0.3 \\
\hline COST ELEMENTS & \multicolumn{3}{|c|}{ FY 1996 Approved Funding Budget } & \multicolumn{3}{|c|}{ FY 1996 Unfunded Budget } & \multicolumn{3}{|c|}{ FY 1996 Baseline Budget } \\
\hline Labor - Regular & & & 1,601 & & & & & & 1,601 \\
\hline . Labor - Overtime & & & & & & & & & 0 \\
\hline 0 Total Labor & & & 1,601 & & & 0 & & & 1,601 \\
\hline 1 Materials & & & 31 & & & & & & 31 \\
\hline 2 Purchased Services & & & 28 & & & & & & 28 \\
\hline 3 Other Hanford & & & 4 & & & & & & 4 \\
\hline Subtotal originated costs. & & & 1,664 & & & 0. & & & 1,664 \\
\hline 4 Site Services & & & 3 & & & & & & 3 \\
\hline 5 Internal Charges & & & & & & & & & 0 \\
\hline 6 IRM Support & & & 24 & & & & & & 24 \\
\hline 7 Overheads & & & 443 & & & & & & 443 \\
\hline 8 Revenue & & & & & & & & & 0 \\
\hline TOTAL DOLLARS & & & 2,134 & & & 0 & & & 2,134 \\
\hline $\begin{array}{l}\text { SIGNATURES } \\
\text { Financial Analyst: } \\
\text { CAM: }\end{array}$ & . & - & $\begin{array}{l}\text { Date: } \\
\text { Date: }\end{array}$ & & BASELINE API & PROVAL & & & Date: \\
\hline
\end{tabular}




\begin{tabular}{|c|c|c|c|c|c|}
\hline \multirow{6}{*}{$\begin{array}{l}\text { Work } \\
\text { Breakdown } \\
\text { Structure } \\
\text { Dictionary }\end{array}$} & \multirow{6}{*}{\multicolumn{3}{|c|}{$\begin{array}{c}\text { Westinghouse Hanford Company } \\
\text { Safeguards and Security } \\
\text { Part I - Summary } \\
\text { (Dollars in } 000^{\prime} s \text { ) }\end{array}$}} & \multirow{8}{*}{$\begin{array}{l}\text { FY } 1996 \text { SSPP } \\
\text { Rev. \# } 0\end{array}$} & Funding Source: \\
\hline & & & & & G\&A $\quad X X$ \\
\hline & & & & & sws \\
\hline & & & & & OST \\
\hline & & & & & $\mathrm{DOH}$ \\
\hline & & & & & MGT PRO \\
\hline Cost Account & \multirow{2}{*}{\multicolumn{3}{|c|}{ G\&A Safeguards and Security: }} & & POOL \\
\hline 1MDD3X & & & & & \begin{tabular}{|l|} 
DIRECT \\
\end{tabular} \\
\hline $\begin{array}{ll}\text { SMS WBS } & 6.6 .2 \\
\end{array}$ & \multicolumn{3}{|c|}{ G\&A Safeguards and Security: } & \multirow{2}{*}{\multicolumn{2}{|c|}{$\begin{array}{c}\text { Annualized Rate } \\
\text { (For Organizational Overhead and } \\
\text { Rated Service Pool Use Only) }\end{array}$}} \\
\hline CAM Review/Approval & \multicolumn{2}{|c|}{ C.W. Walton } & $\begin{array}{l}\text { Daty: } \\
\text { Date }\end{array}$ & & \\
\hline SMS Program Manager Review/Approval & \multicolumn{2}{|r|}{ C.W. Walton } & Date & FY 1995 Rate & FY 1996 Rate \\
\hline Financial Manager Review/Approval & \multicolumn{2}{|r|}{ F.D. Lee } & Date & $-N / A-$ & $-N / A-$ \\
\hline Responsible Analyst & \multicolumn{2}{|r|}{ L.V. Jones } & Date & FY 1996 Target Rate & FY 1996 Approved Rate \\
\hline OSBRB Review/Approval & & & Date & $-N / A-$ & $-N / A-$ \\
\hline & FY19: & 95 & & FY 1996 & \\
\hline FULL-TIME EQUIVALENTS (FTES) & Budget & $\begin{array}{c}\text { Fiscal Year Spending } \\
\text { Forecast (FYSF) }\end{array}$ & Target & Request & $\begin{array}{l}\text { Approved } \\
\text { Baseline }\end{array}$ \\
\hline Organizational - Exempt & 27.8 & & & 17.0 & \\
\hline Organizational - Nonexempt & 9.2 & & & 7.5 & \\
\hline Organizational - Bargaining & & & & 0.3 & \\
\hline Total Organizational FTEs & 37.0 & & & 24.8 & \\
\hline Support FTEs & & & & 0.8 & \\
\hline TOTAL FTES & 37.0 & & & 25.6 & \\
\hline$\frac{1.7}{\text { COST ELEMENTS }}$ & 1 & & & & \\
\hline Labor - Regular & 2105 & & & 1601 & \\
\hline . Labor - Overtime & 6 & & & & \\
\hline 0 Total Labor & 2,111 & & & 1,601 & \\
\hline 1 Materials & 40 & & & 31 & \\
\hline 2 Purchased Services & 51 & & & 28 & \\
\hline 3 Other Hanford & 24 & & & 4 & \\
\hline 4 Site Services & 18 & & & 3 & \\
\hline 5 Internal Charges & & & & & \\
\hline 6 IRM Support & 118 & & & 24 & \\
\hline 7 Overheads & 897 & & & 443 & \\
\hline 8. Revenue & & & & & \\
\hline TOTALDOLLARS & 3,259 & 3,173 & & 2,134 & \\
\hline
\end{tabular}




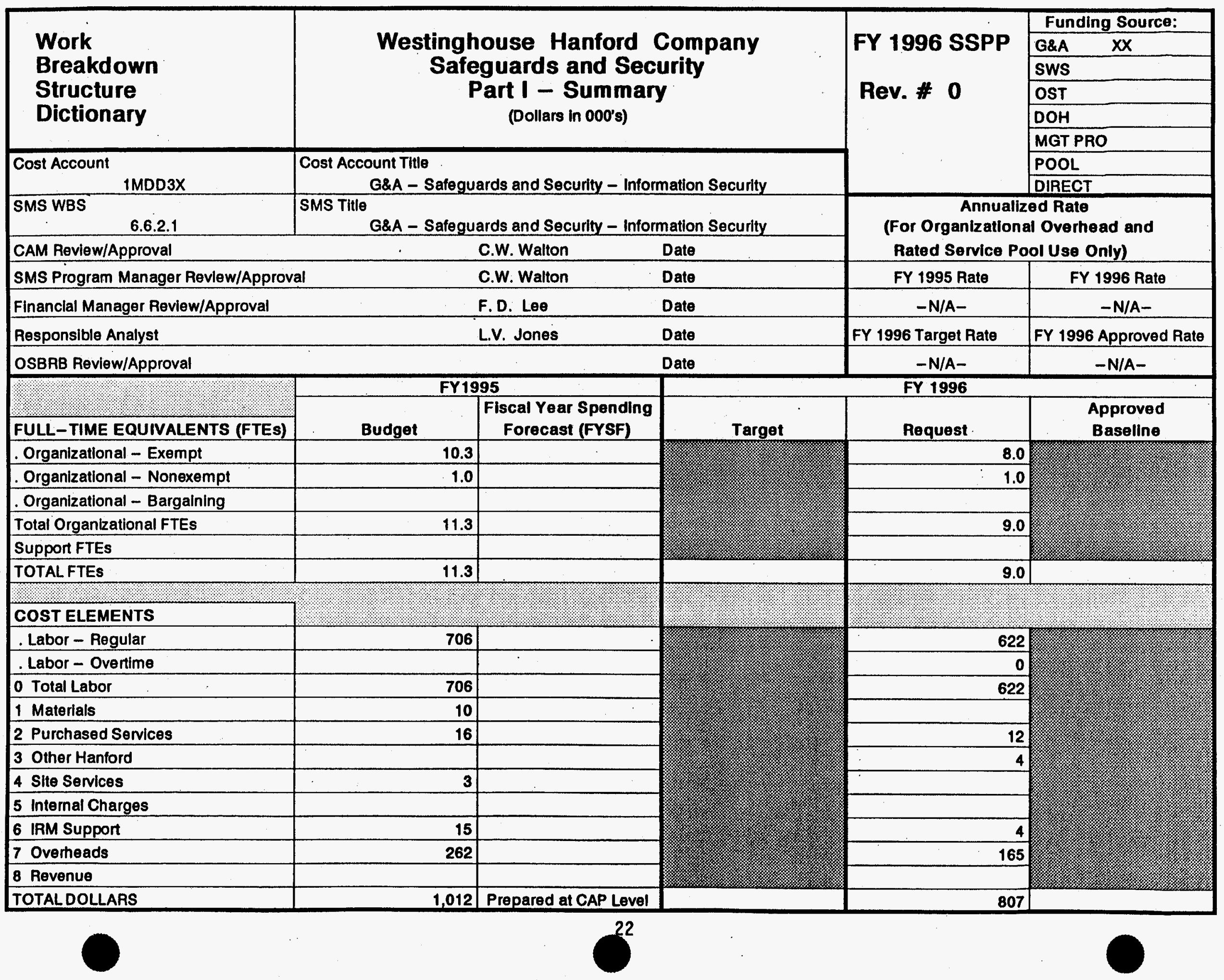




\begin{tabular}{|l|c|c|}
\hline \multicolumn{1}{|c|}{ COST ACCOUNT } & \multicolumn{2}{|c|}{ Fy 1996 SSPP } \\
\hline $\begin{array}{l}\text { Work Breakdown } \\
\text { Structure } \\
\text { Dictionary }\end{array}$ & $\begin{array}{c}\text { Westinghouse Hanford Company } \\
\text { Safeguards and Security } \\
\text { Part II - Element Definition }\end{array}$ & Revision \#0 \\
\hline
\end{tabular}

\begin{tabular}{|l|l|}
\hline WBS ELEMENT CODE: 6.6.2.1 & TITLE: Information Security \\
\hline
\end{tabular}

\section{ELEMENT TASK DESCRIPTION}

FUNDING SOURCE: General and Administrative (G\&A)

\section{TASK DESCRIPTION:}

Classification:

- Implement and sustain a program that identifies classified information to ensure its protection.

Elimination of this task would allow loss of control of classified information in violation of the provisions of Section 141 and 142 of the U.S. Atomic Energy Act and Executive Order 12958 which establish requirements for control of information. Loss of Unclassified, Controlled Nuclear Information (UCNI) through negligence could subject Westinghouse Hanford Company (WHC) and its officers to severe criminal penalties under Title 18 USC Section 793. Fines and assessments for failure to implement adequate measures to identify and protect classified information.

\section{Classified Computer Security:}

- Ensure the security of classified information processed and stored on computers.

Elimination of this task would allow loss of control of classified national security information. Fines and assessments for failing to properly implement the Executive Order on National Security Information and OMB Circular A-130. 
COST ACCOUNT

\begin{tabular}{l|c} 
Work Breakdown & Westinghouse Hanford Company \\
Structure & Safeguards and Security \\
Dictionary & Part II - Element Definition
\end{tabular}

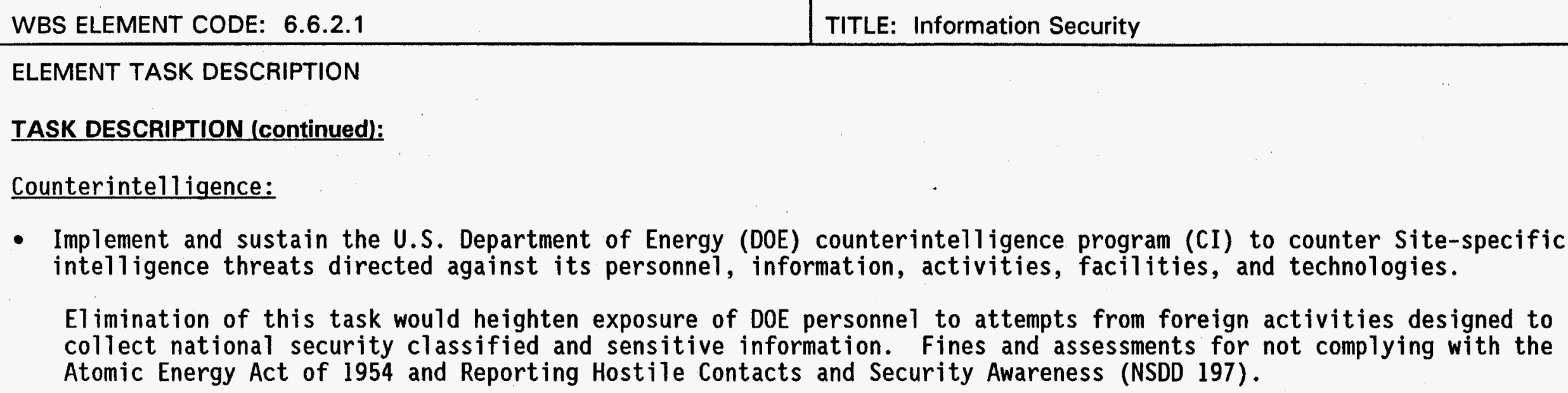

Operations Security:

- Provide reasonable assurance that sensitive information regarding national security and energy programs are protected from compromise and secured against unauthorized disclosure. Ensure that foreign visitors and assignees do not access Export-controlled information (ECI) or Applied Technology.

Elimination of this task would allow loss of control of national security information. Fines and assessments levied for failing to implement Executive Orders to protect national security information and National Security Decision Orders for OPSEC and nuclear weapons. 
COST ACCOUNT

\begin{tabular}{|l|c|}
\hline Work Breakdown & Westinghouse Hanford Company \\
Structure & Safeguards and Security \\
Dictionary & Part II - Element Definition \\
\hline
\end{tabular}

\begin{tabular}{|l|l}
\hline WBS ELEMENT CODE: 6.6.2.1 & TITLE: Information Security \\
\hline
\end{tabular}

\section{ELEMENT TASK DESCRIPTION}

\section{TASK DESCRIPTION (continued):}

Unclassified Computer Security:

- Develop, implement, and sustain the DOE Unclassified Computer Security Program. This program encompasses the computers, data, software, and networks used to process DOE and WHC information.

Elimination of this task would allow loss of control over information protected by public law (ECI, AT, Privacy, UCNI, etc). Fines and assessments for not providing the means to enact provisions of the Computer Security Act of 1987, the Management of Federal Information Resources (OMB Cir A-130), and the National Policy on Telecommunications and Automated Information Systems Security.

\section{Misc. Information Security:}

Implement and maintain technical security programs in the areas of TEMPEST and TSCM.

The risk associated with these programs are low.

\section{ASSUMPTIONS:}

\section{Classified Computer Security:}

This program will continue to be used to support both WHC and DOE Richland Operations Officer (RL) classified processing requirements. Telecommunications Security (COMSEC, TEMPEST, and Protected Distribution Systems) will be conducted as part of the WHC Classified Computer Security Program. Staffing for this program will not be increased. 
COST ACCOUNT

\begin{tabular}{|l|c|}
\hline Work Breakdown & Westinghouse Hanford Company \\
Structure & Safeguards and Security \\
Dictionary & Part II - Element Definition
\end{tabular}

\section{WBS ELEMENT CODE: 6.6 .2 .1}

TITLE: Information Security

\section{ELEMENT TASK DESCRIPTION}

ASSUMPTIONS (continued):

\section{Counterintelligence:}

This newest Information Security program will continue to grow in fiscal year (FY) 1996 . Travel to foreign countries requiring special CI pre- and post-travel briefings will increase to require more than double the number of briefings conducted in FY 1995. Special visits by foreigners from sensitive countries and from nonsensitive countries involving sensitive subjects will continue to increase, requiring $\mathrm{CI}$ briefings prior to and following the visits. This increased workload will be absorbed by existing staff.

\section{Unclassified Computer Security:}

The requirement to provide computer and telecommunication support to both non-DOE and non-WHC entities will continue to increase. The Site's computer security environment will be subjected to increasing demands placed by other entities requiring remote access to Hanford systems and databases. These demands will require increased coordination and training and will have to be met with no increase in staff.

\section{MILESTONES:}

- 96-01 Complete and implement the WHC Operations Security Plan for FY 1996. This plan will describe those goals and objectives to meet requirements established by RL and the DOE Order 5639.7. 10/31/95

- 96-11 Complete the WHC Computer Protection Plan for FY 1996. 6/30/96 


\begin{tabular}{|l|c|c|}
\hline \multicolumn{2}{|c|}{ COST ACcOUNT } & \multicolumn{2}{|c|}{ FY 1996 SSPP } \\
\hline $\begin{array}{l}\text { Work Breakdown } \\
\text { Structure } \\
\text { Dictionary }\end{array}$ & Westinghouse Hanford Company & Safeguards and Security \\
\hline
\end{tabular}

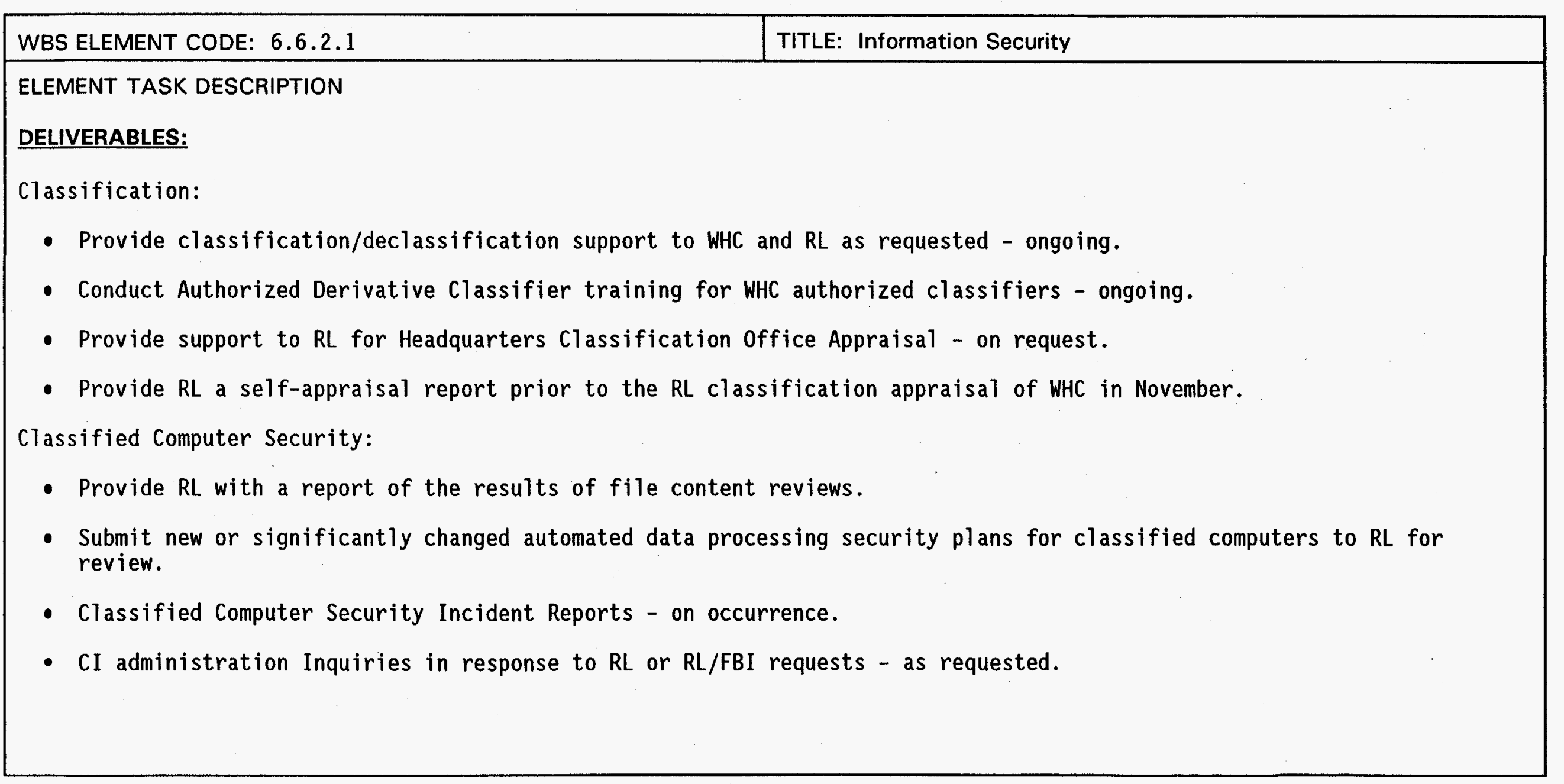




\begin{tabular}{|l|c|c|}
\hline \multicolumn{1}{|c|}{ COST ACCOUNT } & \multicolumn{2}{|c|}{ FY 1996 SSPP } \\
\hline $\begin{array}{l}\text { Work Breakdown } \\
\text { Structure } \\
\text { Dictionary }\end{array}$ & Westinghouse Hanford Company & Safeguards and Security \\
\hline
\end{tabular}

\begin{tabular}{|l|l|}
\hline WBS ELEMENT CODE: 6.6 .2 .1 & TITLE: Information Security \\
\hline ELEMENT TASK DESCRIPTION \\
DELIVERABLES (continued): \\
Counterintell igence: \\
- CI Contact/Incident Reports to RL of which WHC employee travel to sensitive foreign countries (80-100) - ongoing. \\
- CI Contact/Incident Reports to RL of host/escorts of foreign visitors from sensitive countries (100-200) - ongoing. \\
Unclassified Computer Security: \\
- Status of unannounced random file content review to RL - quarterly. \\
- Unclassified Computer Security Incident Reports - on occurrence. \\
- Provide RL with a report of the results of file content reviews. \\
workstations.
\end{tabular}




\begin{tabular}{|l|c|c|}
\hline \multicolumn{2}{|c|}{ COST ACCOUNT } & \multicolumn{2}{|c|}{ Westinghouse Hanford Company } & F996 SSPP \\
\hline $\begin{array}{l}\text { Work Breakdown } \\
\text { Structure } \\
\text { Dictionary }\end{array}$ & Safeguards and Security & Revision \#0 \\
\hline
\end{tabular}

\begin{tabular}{|l|l|}
\hline WBS ELEMENT CODE: 6.6 .2 .1 & TITLE: Information Security \\
\hline ELEMENT TASK DESCRIPTION \\
DELIVERABLES (continued): \\
Operations Security: \\
- Maintain 1istings of sensitive and security facilities for RL - quarterly. \\
- Review foreign visit/assignment specific security plans for OPSEC interests and program approval prior to WHC \\
- Submitted to RL - ongoing. \\
- Submit WHC FY 1996 OPSEC Plan to RL - October 1, 1995. \\
- Submit results of OPSEC Assessments to RL upon completion. \\
$\quad$
\end{tabular}




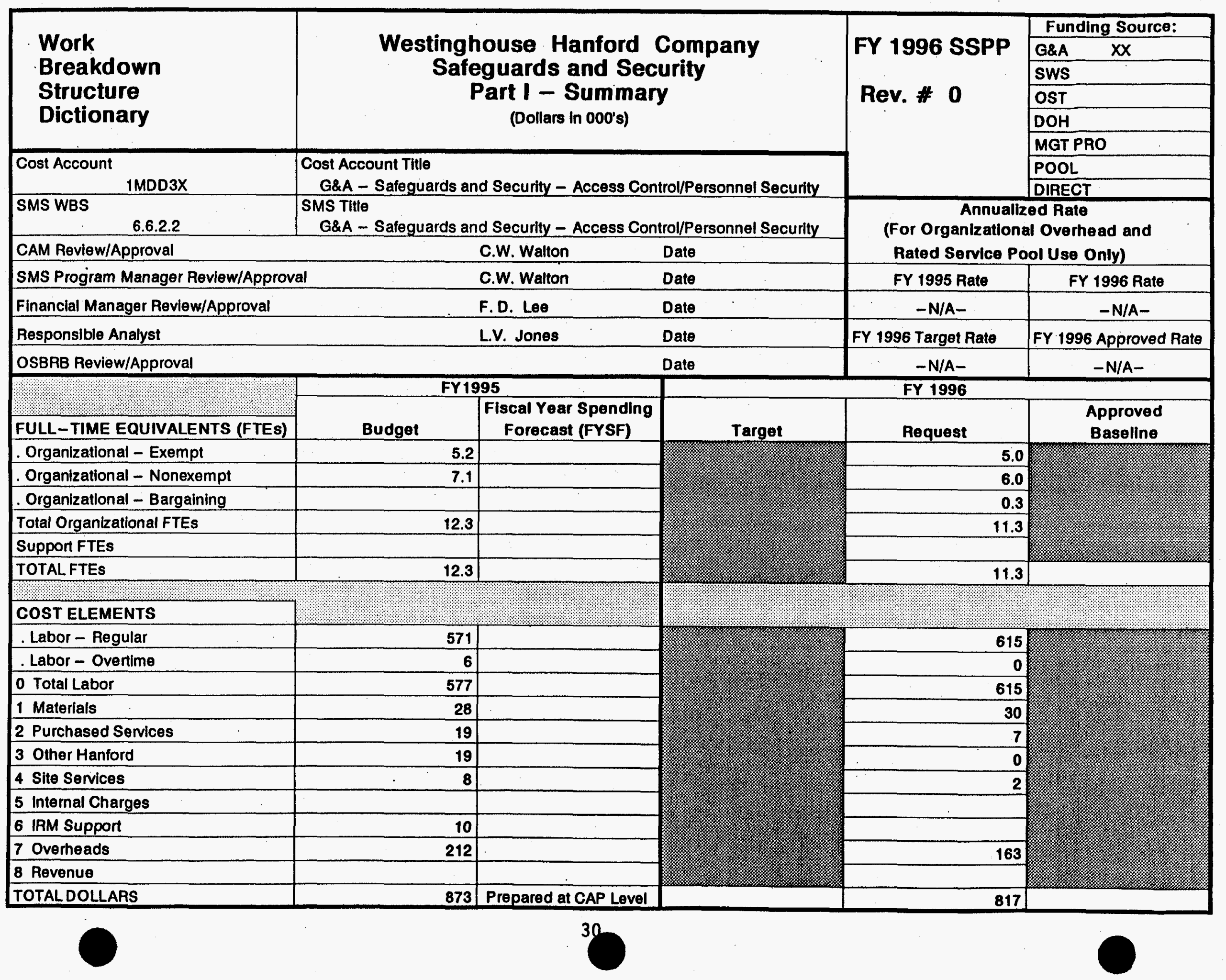





\begin{tabular}{|l|c|c|}
\hline \multicolumn{1}{|c|}{ COST ACCOUNT } & \multicolumn{2}{|c|}{ Westinghouse Hanford Company } \\
\hline $\begin{array}{l}\text { Work Breakdown } \\
\text { Structure } \\
\text { Dictionary }\end{array}$ & Part II - Elements Definition & Revision \#0 \\
\hline
\end{tabular}

WBS ELEMENT CODE: 6.6 .2 .2

TITLE: Access Control/Personnel Security

ELEMENT TASK DESCRIPTION

TASK DESCRIPTION (continued):

Obtain security badges, keys, proximity cards, etc., from terminating employees and coordinate with Physical Security their removal from automated access control systems.

Develop, maintain, and provide to DOE a continuing five-year security clearance need estimate for WHC, ICF KH, and BCSR.

Coordinate with HR the tracking of cleared personnel who are on a leave of absence and ensure termination of unused

clearances according to DOE Order.

Develop and administer procedures for requesting, obtaining and maintaining "Special Access," ie., SIGMA, DOD, etc. for WHC, ICF KH, and BCSR.

Implement procedures for reporting arrests, convictions, name changes, and other reporting requirements to DOE.

Provide coordination with BCSR IRM, RL, Pacific Northwest Laboratory, ICF KH, and Bechte1 Hanford, Inc., concerning use, maintenance, and upgrade of automated data processing systems.

Elimination of this task would have the following consequences:

Uncontrolled Site access in violation of Section 161 of the U.S. Atomic Energy Act which mandates that only persons whose character, associations, and loyalty have been established through investigation shall have access to Restricted Data and SNM. Increases in significant theft/sabotage risks, National security threat, and Safety and security liabilities would result. 
COST ACCOUNT

\begin{tabular}{|l|c|}
\hline Work Breakdown & Westinghouse Hanford Company \\
Structure & Safeguards and Security \\
Dictionary & Part II - Element Definition \\
\hline
\end{tabular}

FY 1996 SSPP

Part II - Element Definition

Revision \#0

WBS ELEMENT CODE: 6.6 .2 .2

TITLE: Access Control/Personnel Security

\section{ELEMENT TASK DESCRIPTION}

IASK DESCRIPTION (continued):

It would become impossible to provide security badging services to determine specific training needs prior to granting access. There would be no electronic record of Site access and a loss of reengineering cost savings/efficiencies/Site standardization.

Heightened liabilities due to allowing unauthorized personnel access to classified security interests. Increased security and safety risks to Site employees.

There would be a loss of control (as required by DOE Order) for access by foreign nationals, resulting in a National security threat.

Potential access to classified security interests could be granted to unauthorized personnel.

Increased risk that terminated employees could gain unauthorized access to classified material.

RL would be unable to forecast budget estimates for clearance purposes.

Access to SIGMA, DOD, and other special access information and material would be denied.

Result in inability to report information of a personnel security concern to RL for continuation of security clearances. Automated data systems integrity would be jeopardized. Identification and resolution of system problems would not be accomplished. 


\begin{tabular}{|l|c|c|}
\hline \multicolumn{1}{|c|}{ COST ACCOUNT } & \multicolumn{2}{|c|}{} \\
\hline $\begin{array}{l}\text { Work Breakdown } \\
\text { Structure } \\
\text { Dictionary }\end{array}$ & $\begin{array}{c}\text { Westinghouse Hanford Company } \\
\text { Safeguards and Security } \\
\text { Part II - Element Definition }\end{array}$ & FY 1996 SSPP \\
\hline
\end{tabular}

\begin{tabular}{|l|l|}
\hline WBS ELEMENT CODE: 6.6 .2 .2 & TITLE: Access Control/Personnel Security \\
\hline ELEMENT TASK DESCRIPTION \\
ASSUMPTIONS: \\
None identified. \\
MILESTONES: \\
- $96-18$ Conduct quarterly internal self-evaluations of the self-expiring and building-specific badging procedures of WHC, \\
BCSR, and ICF KH. \\
DELIVERABLES: \\
- 1st Quarter Self-evaluation Report \\
- 3rd Quarter Self-evaluation Report \\
- 4th Quarter Self-evaluation Report \\
Develop a Hanford Security Badge Request form with implementation contingent upon agreement by all site contractors.
\end{tabular}




\begin{tabular}{|c|c|c|c|c|c|}
\hline \multirow{6}{*}{$\begin{array}{l}\text { Work } \\
\text { Breakdown } \\
\text { Structure } \\
\text { Dictionary }\end{array}$} & \multirow{6}{*}{\multicolumn{3}{|c|}{$\begin{array}{c}\text { Westinghouse Hanford Company } \\
\text { Safeguards and Security } \\
\text { Part I - Summary } \\
\text { (Dollars in 000's) }\end{array}$}} & \multirow{8}{*}{$\begin{array}{l}\text { FY } 1996 \text { SSPP } \\
\text { Rev. \# } 0\end{array}$} & Funding Source: \\
\hline & & & & & G\&A $\quad X X$ \\
\hline & & & & & sws \\
\hline & & & & & OST \\
\hline & & & & & $\mathrm{DOH}$ \\
\hline & & & & & MGT PRO \\
\hline Cost Account & \multirow{2}{*}{\multicolumn{3}{|c|}{$\begin{array}{l}\text { Cost Account Title } \\
\text { G\&A - Safeguards and Security - IRM Support }\end{array}$}} & & POOL \\
\hline $1 \mathrm{MDD} 3 \mathrm{X}$ & & & & & DIRECT \\
\hline $\begin{array}{ll}\text { SMS WBS } & \\
& 6.6 .2 .3 \\
\end{array}$ & \multicolumn{3}{|c|}{ G\&A - Safeguards and Security - IRM Support } & \multirow{2}{*}{\multicolumn{2}{|c|}{$\begin{array}{c}\text { Annualized Rate } \\
\text { (For Organizational Overhead and } \\
\text { Rated Service Pool Use Only) }\end{array}$}} \\
\hline CAM Review/Approval & \multicolumn{2}{|r|}{ C.W. Walton } & Date & & \\
\hline \multicolumn{2}{|l|}{ SMS Program Manager Review/Approval } & C.W. Walton & Date & FY 1995 Rate & FY 1996 Rate \\
\hline \multicolumn{2}{|l|}{ Financial Manager Review/Approval } & F.D. Lee & Date & $-N / A-$ & $-N / A-$ \\
\hline \multicolumn{2}{|l|}{ Responsible Analyst } & L.V. Jones & Date & FY 1996 Target Rate & FY 1996 Approved Rate \\
\hline OSBRB Review/Approval & & & Date & $-N / A-$ & $-N / A-$ \\
\hline & FY19 & 995 & & FY 1996 & \\
\hline FULL-TIME EQUIVALENTS (FTES) & Budget & $\begin{array}{c}\text { Fiscal Year Spending } \\
\text { Forecast (FYSF) }\end{array}$ & Target & Request & $\begin{array}{l}\text { Approved } \\
\text { Baseline }\end{array}$ \\
\hline Organizational - Exempt & 5.9 & & & & \\
\hline . Organizational - Nonexempt & & & & & \\
\hline . Organizational - Bargaining & & 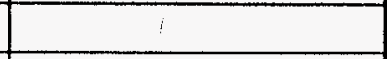 & & & \\
\hline Total Organizational FTEs & 5.9 & & & 0.0 & \\
\hline Support FTEs & & & & 0.8 & \\
\hline TOTALFTES & 5.9 & & & 0.8 & \\
\hline COST ELEMENTS & & & & & \\
\hline . Labor - Regular & 374 & & & 53 & \\
\hline . Labor - Overtime & & & & 0 & \\
\hline 0 Total Labor & 374 & & & 53 & \\
\hline 1 Materials & & & & & \\
\hline 2 Purchased Services & & & & & \\
\hline 3 Other Hanford & 5 & & & & \\
\hline 4 Site Services & & & & & \\
\hline 5 Internal Charges & & & & & \\
\hline 6 IRM Support & 48 & . & & & \\
\hline 7 Overheads & 243 & & & 32 & \\
\hline 8 Revenue & & & & & \\
\hline TOTALDOLLARS & 670 & Prepared at CAP Level & & 85 & \\
\hline
\end{tabular}




\begin{tabular}{|l|c|c|}
\hline \multicolumn{2}{|c|}{ COST ACCOUNT } & Westinghouse Hanford Company \\
\hline $\begin{array}{l}\text { Work Breakdown } \\
\text { Structure } \\
\text { Dictionary }\end{array}$ & $\begin{array}{c}\text { Safeguards and Security } \\
\text { Part II - Element Definition }\end{array}$ & FY 1996 SSPP \\
\hline
\end{tabular}

\begin{tabular}{l}
\hline WBS ELEMENT CODE: 6.6.2.3 \\
\hline ELEMENT TASK DESCRIPTION \\
FUNDING SOURCE: General and Administrative (GRA) \\
TASK DESCRIPTION: \\
BCSR IRM support maintains both the Digital Imaging Security Badging System (DIS) and the PSCR+ database, both of which are \\
essential for allowing Site access to employees and visitors. IRM is responsible for modifications to the DIS and PSCR+ \\
systems as customer requirements change. \\
ASSUMPTIONS \\
None identified. \\
MILESTONES: \\
None identified. \\
DELIVERABLES: \\
None identified.
\end{tabular}




\begin{tabular}{|c|c|c|c|c|c|}
\hline \multirow{6}{*}{$\begin{array}{l}\text { Work } \\
\text { Breakdown } \\
\text { Structure } \\
\text { Dictionary }\end{array}$} & \multirow{6}{*}{\multicolumn{3}{|c|}{$\begin{array}{c}\text { Westinghouse Hanford Company } \\
\text { Safeguards and Security } \\
\text { Part I - Summary } \\
\text { (Dollars in } 000^{\prime} \text { ) }\end{array}$}} & \multirow{8}{*}{$\begin{array}{l}\text { FY } 1996 \text { SSPP } \\
\text { Rev. \# } 0\end{array}$} & Funding Source: \\
\hline & & & & & G\&A $\quad X X$ \\
\hline & & & & & sws \\
\hline & & & & & OST \\
\hline & & & & & DOH \\
\hline & & & & & MGT PRO \\
\hline Cost Account & \multirow{2}{*}{\multicolumn{3}{|c|}{$\begin{array}{l}\text { Cost Account Title } \\
\text { G\&A - Safeguards and Security - Investigations }\end{array}$}} & & POOL \\
\hline 1MDD3X & & & & & DIRECT \\
\hline $\begin{array}{ll}\text { SMS WBS } & \\
\end{array}$ & \multicolumn{3}{|c|}{ G\&A - Safeguards and Security - Investigations } & \multirow{2}{*}{\multicolumn{2}{|c|}{$\begin{array}{c}\text { Annualized Rate } \\
\text { (For Organizational Overhead and } \\
\text { Rated Service Pool Use Only) }\end{array}$}} \\
\hline CAM Review/Approval & \multicolumn{2}{|r|}{ C.W. Walton } & & & \\
\hline \multicolumn{2}{|l|}{ SMS Program Manager Review/Approval } & C.W. Walton & Date & FY 1995 Rate & FY 1996 Rate \\
\hline \multicolumn{2}{|l|}{ Financial Manager Review/Approval } & F.D. Le日 & Date & $-N / A-$ & $-N / A-$ \\
\hline \multicolumn{2}{|l|}{ Responsible Analyst } & L.V. Jones & Date & FY 1996 Target Rate & FY 1996 Approved Rate \\
\hline OSBRB Review/Approval & & & Date & $-N / A-$ & $-N / A-$ \\
\hline & FY19 & 995 & & FY 1996 & \\
\hline FULL-TIME EQUIVALENTS (FTES) & Budget & $\begin{array}{c}\text { Fiscal Year Spending } \\
\text { Forecast (FYSF) }\end{array}$ & Target & Request & $\begin{array}{l}\text { Approved } \\
\text { Baseline }\end{array}$ \\
\hline . Organizational - Exempt & 3.5 & & & 2.0 & \\
\hline . Organizational - Nonexempt & 0.5 & & & 0.5 & \\
\hline . Organizational - Bargaining & & & & & \\
\hline Total Organizational FTEs & 4.0 & & & 2.5 & \\
\hline Support FTEs & & & & & \\
\hline TOTAL FTES & 4.0 & & & 2.5 & \\
\hline COST ELEMENTS & & & & & \\
\hline . Labor - Regular & 246 & & & 165 & \\
\hline . Labor - Overtime & & & & 0 & \\
\hline 0 Total Labor & 246 & & & 165 & \\
\hline 1 Materials & & & & & \\
\hline 2 Purchased Services & 10 & & & 5 & \\
\hline 3 Other Hanford & & & & & \\
\hline 4 Site Services & 6 & & & & \\
\hline 5 internal Charges & & & & & \\
\hline 6 IRM Support & 14 & & & & \\
\hline 7 Overheads & 103 & & & 44 & \\
\hline 8 Revenue & & & & & \\
\hline TOTALDOLLARS & 379 & Prepared at CAP Level & & 214 & \\
\hline
\end{tabular}


COST ACCOUNT

\begin{tabular}{|l|c|}
\hline Work Breakdown & Westinghouse Hanford Company \\
Structure & Safeguards and Security \\
Dictionary & Part II - Element Definition
\end{tabular}

WBS ELEMENT CODE: 6.6 .2 .4

TITLE: Security Investigations

ELEMENT TASK DESCRIPTION

FUNDING SOURCE: General and Administrative (G\&A)

\section{TASK DESCRIPTION:}

The Security Investigations Office (SIO) conducts investigations of security violations involving Category I and II SNM, Limited and Protected Areas, classified information, and prohibited articles. SIO also conducts special inquiries into sensitive matters as requested by RL and WHC management. Additionally, S10 maintains a Hanford Site security event database for RL and performs regular analysis and trending of incidents to identify and report security anomalies. SIO acts as point of contact pertaining to criminal matters and information with RL, Benton County Sheriffs office (BCSO), and the Inspector General (IG).

Elimination of this task would result in the following consequences:

WHC would be in violation of FAR Chapter 1, Subchapter G - Contract Management, Part 45.504 - Contractor Liability, which requires the contractor to investigate and report all cases of loss, damage, or destruction of government property.

Noncompliance to DOE Orders to investigate security incidents.

Loss of capability to maintain a security incident database and trend thefts and security violations.

Reduced capability to determine root causes for security incidents and initiate corrective actions and procedural changes/clarifications.

Limit our ability to administer the security infraction program.

Loss of dignitary protection and 1 aw enforcement interface. 


\begin{tabular}{|l|c|c|}
\hline \multicolumn{2}{|c|}{ COST ACCOUNT } & \multicolumn{2}{|c|}{ FY 1996 SSPP } \\
\hline $\begin{array}{l}\text { Work Breakdown } \\
\text { Structure } \\
\text { Dictionary }\end{array}$ & $\begin{array}{c}\text { Westinghouse Hanford Company } \\
\text { Safeguards and Security } \\
\text { Part II - Element Definition }\end{array}$ & Revision \#0 \\
\hline
\end{tabular}

\begin{tabular}{|l|l|l|}
\hline WBS ELEMENT CODE: 6.6 .2 .4 & TITLE: Security Investigations \\
\hline
\end{tabular}

\section{ELEMENT TASK DESCRIPTION}

ASSUMPTIONS:

- Security Investigations will be conducted only for incidents defined as significant by RL. Event tracking and analyses will be performed to identify significant events/trends.

\section{MILESTONES:}

- 96-08 Develop a CRIME STOPPER prototype program for the Hanford Site. 5-31-96 (Implementation will be done by BCSO)

DELIVERABLES:

- Investigations of reported/alleged non-compliance to DOE/WHC security directives.

- Investigations requested by RL after deferral from DOE-IG or BCSO.

- Investigations by special request into internal/external matters of a security interest not specifically delineated with in DOE Order or company policy.

- Analysis for Hanford Site occurrence reports to assess disposition of SAS interests.

- Weekly security incident report/update.

- Quarterly Security Incident Trend Analysis report. 


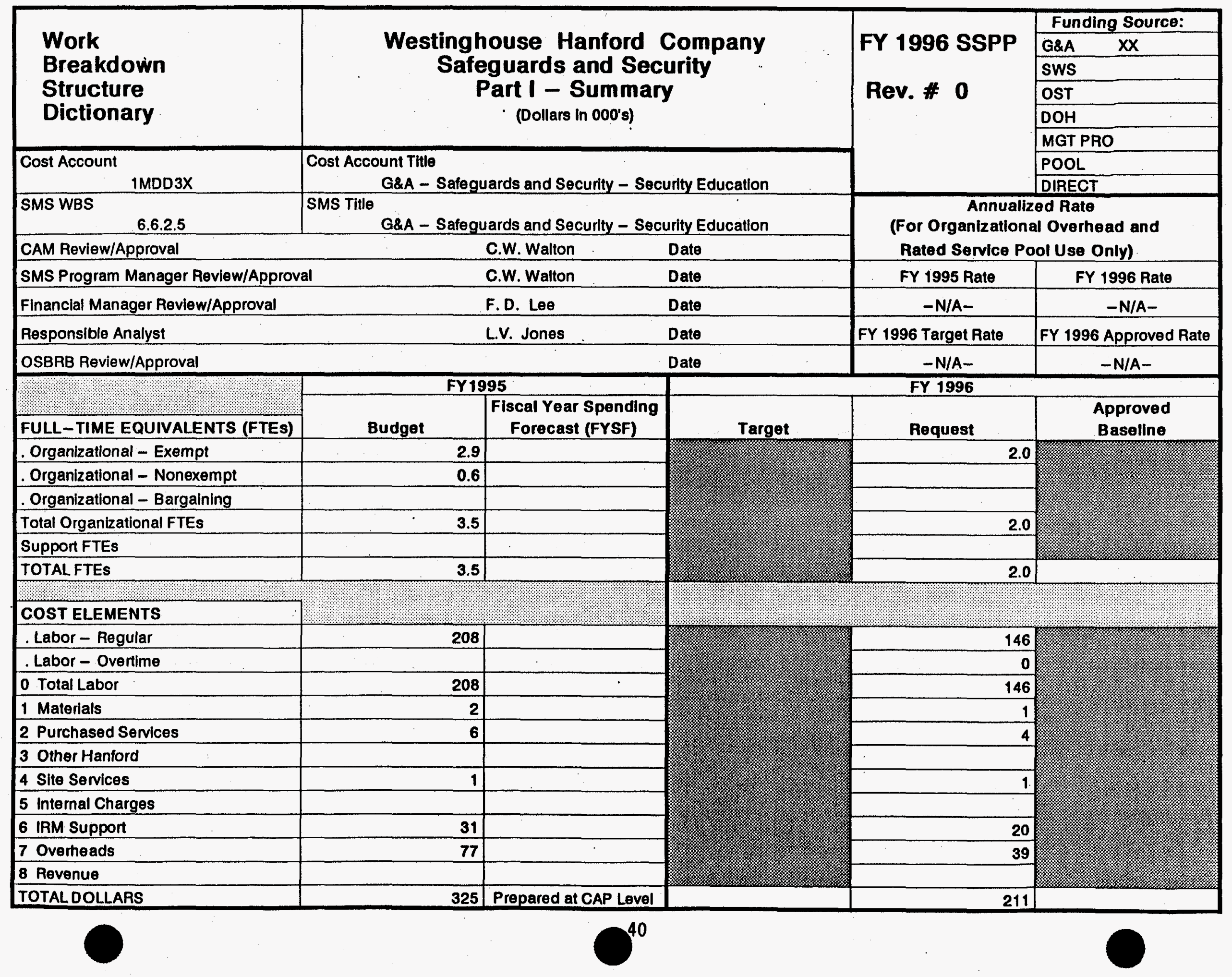



COST ACCOUNT

Work Breakdown

Structure

Dictionary
Westinghouse Hanford Company

Safeguards and Security

Part II - Element Definition
FY 1996 SSPP

Revision \#0

\begin{tabular}{l}
\hline WBS ELEMENT CODE: 6.6 .2 .5 \\
\hline ELEMENT TASK DESCRIPTION \\
TASK DESCRIPTION (continued): \\
Lack of knowledge/understanding by cleared personnel concerning their responsibilities to protect classified information \\
and materials; considered a national security threat. Denial of DOE security clearances and inability to accomplish \\
work in security areas. \\
Formerly cleared personnel would not be aware of continuing personnel security reporting requirements. Signed \\
termination statements would not be obtained and forwarded to DOE. \\
Loss of efficiency and centralized focus. Loss of employee awareness of SAS issues would decline. \\
Potential liability risks. \\
ASSUMPTIONS: \\
- The HGET Programs will be revised to reflect ongoing security changes. \\
- Assistance will be provided to RL SAS as requested. \\
MILESTONES: \\
None identified.
\end{tabular}





\begin{tabular}{|c|c|c|}
\hline & $\begin{array}{c}\text { Westinghouse Hanford Company } \\
\text { Safeguards and Security } \\
\text { WBS 6.6 }\end{array}$ & $\begin{array}{c}\text { FY 1996 } \\
\text { Program Plan } \\
\text { August 31, 1995 }\end{array}$ \\
\hline
\end{tabular}

Total FY 1996

\begin{tabular}{|c|c|c|c|}
\hline SMS & Sitewide Support WBS/SMS 6.6.3 & FTE & $\$ \ln 000^{\prime} s$ \\
\hline 6.6.3.1 & Technical Support Services & 3. & 340 \\
\hline 6.6 .3 .2 & Performance Testing and Surveys & 2.2 & 334 \\
\hline 6.6.3.3 & Radiological/Toxicological VA Analysis & 3.2 & 295 \\
\hline 6.6.3.4 & Site Safeguards and Security Plans & .7 & 81 \\
\hline 6.6 .3 .5 & Threat Evaluation & .6 & 53 \\
\hline 6.6 .3 .6 & Northern Area Industrial Security Engineering & .7 & 59 \\
\hline 6.6.3.7 & Northern Operations Industrial Security & 1.1 & 102 \\
\hline 6.6.3.8 & Northern Area Industrial Security IRM Support & .4 & 42 \\
\hline 6.6 .3 .9 & Badging Operations & 8.3 & 634 \\
\hline 6.6.3.10 & Southern Area Industrial Security (Security Maint.) & 3.7 & 321 \\
\hline 6.6.3.11 & Southern Area Industrial Security (Physical Security) & 5.6 & 476 \\
\hline \multirow[t]{3}{*}{6.6 .3 .12} & Industrial Security Administration & 1.9 & 149 \\
\hline & Elimination of cross charging & & (523) \\
\hline & TOTAL: & 31.4 & 2,363 \\
\hline
\end{tabular}




\begin{tabular}{|c|c|c|c|c|c|c|c|c|c|}
\hline $\begin{array}{l}\text { Work } \\
\text { Breakdown } \\
\text { Structure } \\
\text { Dictionary }\end{array}$ & \multicolumn{6}{|c|}{$\begin{array}{c}\text { Westinghouse Hanford Company } \\
\text { Safeguards and Security } \\
\text { Part I - Summary } \\
\text { (Dollars in } 000 \text { 's) }\end{array}$} & \multicolumn{3}{|c|}{$\begin{array}{l}\text { FY } 1996 \\
\text { Indirect } \\
\text { Program Plan } \\
\text { Rev. \# } 0\end{array}$} \\
\hline $\begin{array}{c}\text { Cost Account Number } \\
\text { 1MDBOA }\end{array}$ & \multicolumn{6}{|c|}{ SWS - Safeguards and Security } & \multicolumn{3}{|c|}{$\begin{array}{l}\text { Proposed Rate: } \\
\text { (Rated Service Pool Only) }\end{array}$} \\
\hline $\begin{array}{r}\text { SMS WBS Number } \\
6.6 .3 \\
\end{array}$ & \multicolumn{6}{|c|}{ SWS - Safeguards and Security } & \multicolumn{3}{|c|}{ Funding Source: } \\
\hline RL SMS Program Manger & \multicolumn{6}{|l|}{ J.L. Spracklen } & \multicolumn{3}{|l|}{ sws } \\
\hline Cost Account Manager & \multicolumn{6}{|l|}{ C.W. Walton } & \multicolumn{3}{|l|}{ OST } \\
\hline WHC SMS Program Manager & \multicolumn{6}{|l|}{ C.W. Walton } & \multicolumn{3}{|l|}{$\mathrm{DOH}$} \\
\hline Financial Manager & \multicolumn{6}{|l|}{ F.D. Lee } & \multicolumn{3}{|l|}{ MGT PRO } \\
\hline Responsible Analyst & \multicolumn{6}{|l|}{ L.V. Jones } & \multicolumn{3}{|l|}{ POOL } \\
\hline & \multicolumn{3}{|c|}{$\begin{array}{l}\text { FY } 1996 \text { Approved Funding } \\
\text { Full-Time Equivalents (FTEs) }\end{array}$} & \multicolumn{3}{|c|}{$\begin{array}{l}\text { FY } 1996 \text { Unfunded } \\
\text { Full-Time Equivalents (FTEs) }\end{array}$} & \multicolumn{3}{|c|}{$\begin{array}{c}\text { FY } 1996 \text { Baseline } \\
\text { Full-Time Equivalents (FTEs) }\end{array}$} \\
\hline TYPE OF FTE & Exempt & Non-Exempt & Bargaining & Exempt & Non-Exempt & Bargaining & Exempt & Non-Exempt & Bargaining \\
\hline Organizational & 17.1 & 9.4 & 2.0 & & & & 17.1 & 9.4 & 2.0 \\
\hline Support & 2.6 & & 0.3 & & & & 2.6 & 0.0 & 0.3 \\
\hline TOTALFTES & 19.7 & 9.4 & 2.3 & 0.0 & 0.0 & 0.0 & 19.7 & 9.4 & 2.3 \\
\hline COST ELEMENTS & \multicolumn{3}{|c|}{ FY 1996 Approved Funding Budget } & \multicolumn{3}{|c|}{ FY 1996 Unfunded Budget } & \multicolumn{3}{|c|}{ FY 1996 Baseline Budget } \\
\hline Labor - Regular & & & 1,880 & & & & & & 1,880 \\
\hline . Labor - Overtime & & & & & & & & & 0 \\
\hline 0 Total Labor & & & 1,880 & & & 0 & & & 1,880 \\
\hline 1 Materials & & & 185 & & & & & & 185 \\
\hline 2 Purchased Services & & & 176 & & & & & & 176 \\
\hline 3 Other Hanford & & & 3 & & & & & & 3 \\
\hline Subtotal Originated Costs & & & 2244 & & & 0 & & & 2,244 \\
\hline 4 Site Services & & & 39 & & & & & & 39 \\
\hline 5 Internal Charges & & & & & & & & & 0 \\
\hline 6 IRM Support & & & 80 & & & & & & 80 \\
\hline 7 Overheads & & & 523 & & & & & & 523 \\
\hline 8 Revenue & ; & & & & & & & & 0 \\
\hline TOTAL DOLLARS & & & 2,886 & & & 0 & & & 2,886 \\
\hline $\begin{array}{l}\text { SIGNATURES } \\
\text { Financial Analyst: } \\
\text { CAM: }\end{array}$ & & & $\begin{array}{l}\text { Date: } \\
\text { Date: }\end{array}$ & & BASELINE API & PROVAL & & & Date: \\
\hline
\end{tabular}




\begin{tabular}{|c|c|c|c|c|c|}
\hline \multirow{6}{*}{$\begin{array}{l}\text { Work } \\
\text { Breakdown } \\
\text { Structure } \\
\text { Dictionary }\end{array}$} & \multirow{6}{*}{\multicolumn{3}{|c|}{$\begin{array}{c}\text { Westinghouse Hanford Company } \\
\text { Safeguards and Security } \\
\text { Part I - Summary } \\
\text { (Dollars in } 000^{\prime} \text { 's) }\end{array}$}} & \multirow{8}{*}{$\begin{array}{l}\text { FY } 1996 \text { SSPP } \\
\text { Rev. \# } 0\end{array}$} & \multirow{2}{*}{\begin{tabular}{|l|} 
Funding Source: \\
G\&A \\
\end{tabular}} \\
\hline & & & & & \\
\hline & & & & & sws \\
\hline & & & & & OST \\
\hline & & & & & \begin{tabular}{|l|} 
DOH \\
MGTPRO
\end{tabular} \\
\hline & & & & & MGT PRO \\
\hline \multirow{2}{*}{$\begin{array}{l}\text { Cost Account } \\
1 \mathrm{MDB} 0 \mathrm{~A}\end{array}$} & \multirow{2}{*}{\multicolumn{3}{|c|}{$\begin{array}{l}\text { Cost Account Title } \\
\qquad \text { sws - Safeguards and Security }\end{array}$}} & & POOL \\
\hline & & & & & DIRECT \\
\hline $\begin{array}{ll}\text { SMS WBS } & 6.6 .3 \\
\end{array}$ & \multicolumn{3}{|c|}{ SWS - Safeguards and Security } & \multirow{2}{*}{\multicolumn{2}{|c|}{$\begin{array}{c}\text { Annualized Rate } \\
\text { (For Organizational Overhead and } \\
\text { Rated Service Pool Use Only) }\end{array}$}} \\
\hline CAM Review/Approval & \multicolumn{3}{|c|}{$\begin{array}{ll}\text { C.W. Walton Date } & \text { D }\end{array}$} & & \\
\hline \multicolumn{2}{|l|}{ SMS Program Manager Review/Approval } & C.W. Walton & Date & FY 1995 Rate & FY 1996 Rate Request \\
\hline \multicolumn{2}{|l|}{ Financial Manager Review/Approval } & F.D. Le日 & Date & & $-N / A-$ \\
\hline Responsible Analyst & & L.V. Jones & Date & $\frac{-N / A-}{\text { FY } 1996 \text { Target Rate }}$ & FY 1996 Approved Rate \\
\hline \multicolumn{3}{|l|}{ OSBRB Review/Approval } & Date & $\frac{-N / A-}{F Y 1996}$ & $-N / A-$ \\
\hline & \multicolumn{2}{|c|}{ FÝ1995 } & \multicolumn{3}{|c|}{ FY 1996} \\
\hline FULL-TIME EQUIVALENTS (FTES) & Budget & \begin{tabular}{|c|}
$\begin{array}{c}\text { Fiscal Year Spending } \\
\text { Forecast (FYSF) }\end{array}$ \\
\end{tabular} & Target & Request & $\begin{array}{l}\text { Approved } \\
\text { Baseline }\end{array}$ \\
\hline Organizational - Exempt & 18.7 & & & 17.1 & \\
\hline . Organizational - Nonexempt & 10.9 & & & 9.4 & \\
\hline . Organizational - Bargaining & 3.2 & & & 2.0 & \\
\hline Total Organizational FTEs & 32.8 & & & 28.5 & \\
\hline Support FTEs & 2.2 & & & 2.9 & \\
\hline TOTALFTES & 35.0 & & & 31.4 & \\
\hline COST ELEMENTS & & & & & \\
\hline . Labor - Regular & 1,851 & & & 1,880 & \\
\hline Labor - Overtime & 0 & & & 0 & \\
\hline 0 Total Labor & 1,852 & & & 1,880 & \\
\hline 1 Materials & 130 & & & 185 & \\
\hline 2 Purchased Services & 205 & & & 176 & \\
\hline 3 Other Hanford & 4 & & & 3 & \\
\hline 4 Site Services & 49 & & & 39 & \\
\hline 5 Internal Charges & & & & & \\
\hline 6 IRM Support & 86 & & & 80 & \\
\hline 7 Overheads & 747 & & & 523 & \\
\hline 8 Revenue & & & & 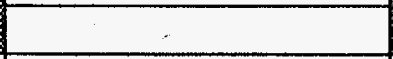 & \\
\hline TOTALDOLLARS & 3,073 & 2,998 & & 2,886 & \\
\hline
\end{tabular}




\begin{tabular}{|c|c|c|c|c|c|}
\hline \multirow{6}{*}{$\begin{array}{l}\text { Work } \\
\text { Breakdown } \\
\text { Structure } \\
\text { Dictionary }\end{array}$} & \multirow{6}{*}{\multicolumn{3}{|c|}{$\begin{array}{c}\text { Westinghouse Hanford Company } \\
\text { Safeguards and Security } \\
\text { Part I - Summary } \\
\text { (Dollars in 000's) }\end{array}$}} & \multirow{8}{*}{$\begin{array}{l}\text { FY } 1996 \text { SSPP } \\
\text { ReV. \# } 0\end{array}$} & \multirow{2}{*}{$\begin{array}{l}\text { Funding Source: } \\
\text { G\&A }\end{array}$} \\
\hline & & & & & \\
\hline & & & & & sws \\
\hline & & & & & OST \\
\hline & & & & & $\mathrm{DOH}$ \\
\hline & & & & & MGT PRO \\
\hline Cost Account & Cost Account Titio & & & & POOL \\
\hline $1 \mathrm{MOBOA44}$ & sws & - Technical Support Ser & ivices & & DIRECT \\
\hline \begin{tabular}{|l} 
SMS WBS \\
$\quad 6.6 .3 .1$ \\
\end{tabular} & SMS Title & - Technical Support Ser & rvices & $\begin{array}{r}\text { Annualize } \\
\text { (For Organizational }\end{array}$ & $\begin{array}{l}\text { ed Rate } \\
\text { al Overhead and }\end{array}$ \\
\hline CAM Review/Approval & & C.W. Walton & Date & Rated Service Poc & ol Use Only) \\
\hline SMS Program Manager Rovlew/Approva & & C.W. Walton & Date & FY 1995 Rate & FY 1996 Rate Request \\
\hline Financial Manager Revlew/Approval & & F.D. Le日 & Date & $-N / A-$ & $-N / A-$ \\
\hline Responsible Analyst & & L.V. Jones & Date & FY 1996 Target Rate & FY 1996 Approved Rate \\
\hline OSBRB Review/Approval & & & Date & $-N / A-$ & $-N / A-$ \\
\hline & FY1S & 995 & & FY 1996 & \\
\hline FULL-TIME EQUIVALENTS (FTES) & Budget & $\begin{array}{c}\text { Fiscal Year Spending } \\
\text { Forecast (FYSF) }\end{array}$ & Target & Request & $\begin{array}{l}\text { Approved } \\
\text { Baseline }\end{array}$ \\
\hline . Organizational - Exempt & 3.3 & & & 3.0 & \\
\hline . Organizational - Nonexempt & 0.4 & & & & \\
\hline Organizational - Bargaining & & & & & \\
\hline Total Organizational FTEs & 3.7 & & & 3.0 & \\
\hline Support FTEs & & & & & \\
\hline TOTALFTES & 3.7 & & & 3.0 & \\
\hline COST ELEMENTS & & & & & \\
\hline . Labor - Regular & 227 & & & 219 & \\
\hline . Labor - Overtime & & & & & \\
\hline 0 Total Labor & 227 & & & 219 & \\
\hline 1 Materlals & 20 & & & 41 & \\
\hline 2 Purchased Services & 21 & & & 16 & \\
\hline 3 Other Hanford & & & & & \\
\hline 4 Site Services & 4 & & & 6 & \\
\hline 5 Internal Charges & & & & & \\
\hline 6 IRM Support & & & & & \\
\hline 7 Overheads & 95 & & & 58 & \\
\hline 8 Revenue & & & & & \\
\hline TOTALDOLLARS & 367 & Prepared at CAP Level & & 340 & \\
\hline
\end{tabular}


COST ACCOUNT

\section{Work Breakdown}

Structure

Dictionary
Westinghouse Hanford Company

Safeguards and Security

Part II - Element Definition
FY 1996 SSPP

Revision \#0

WBS ELEMENT CODE: 6.6.3.1

TITLE: Technical Support Services

\section{ELEMENT TASK DESCRIPTION}

FUNDING SOURCE: Sitewide Support (SWS)

\section{TASK DESCRIPTION:}

- Evaluate cost-effective technology and prepare implementation plans for a fiber optic sensor and spread spectrum communication technology.

Eliminating onsite evaluation of new technologies for actual and/or potential system replacements inhibits improving the efficiency and reducing the operational costs of existing labor-intensive Safeguards and Security (SAS) systems. SAS will not be able to properly apply access control and alarm technologies to theft of Special Nuclear Material (SNM) and radiological/toxicological sabotage issues. Potential impact to Westinghouse Hanford Company (WHC) risk level for these targets. WHC has relied on technology solutions for these issues versus unavailable Patrol resources due to downsizing.

- Technical and administrative support to evaluate and implement SAS requirements by coordinating and facilitating an intercontractor review and update of the Hanford Site SAS Training Program Plan.

A review and update of the Hanford Site SAS Training Program Plan would not be performed by eliminating support in this area. Applicable U.S. Department of Energy (DOE) Orders are currently being revised and new requirements imposed by them would not be addressed by nor reflected in the plan.

- Technical and administrative support to develop an SAS Distance Learning Resource Utilization Implementation Plan.

Distance learning has the potential to significantly reduce training costs associated with offsite travel. SAS has taken the lead role at Hanford in establishing a suitable classroom environment and presenting pilot courses of instruction. Eliminating technical and administrative support would prevent developing the full potential of this capability to include other Hanford organizations that incur travel related training costs. 
COST ACCOUNT

\section{Work Breakdown}

Structure

Dictionary
Westinghouse Hanford Company

Safeguards and Security

Part II - Element Definition
FY 1996 SSPP

Revision \#0

\section{WBS ELEMENT CODE: 6.6.3.1}

TITLE: Technical Support Services

\section{ELEMENT TASK DESCRIPTION}

\section{TASK DESCRIPTION: (cont inued)}

- Produce detailed status reports of Hanford-wide SAS resources and the state of Sitewide SAS operational activities.

Information contained in these documents is used by DOE, Headquarters (HQ) to report the status of the entire complex to Congress and the President. WHC could not assist in the preparation of these status reports if technical and administrative support in this area were suspended.

\section{ASSUMPTIONS:}

- Potential savings exist through the utilization of new technologies to refurbish obsolete SAS systems, to substitute manpower-intensive operations with automated systems, and to replace existing or projected systems. Advances in technology have provided significant cost savings and continues to be a source of further savings.

- Costs will continue to be incurred to meet specific SAS training requirements. Distance learning resources will provide a way to minimize those costs by reducing the need to travel offsite for training.

- Requirements to prepare and submit specific SAS reports will continue. This necessitates a high level of technical expertise and proficiency to produce concise, accurate, and quality documents.

\section{MILESTONES:}

- 96-07 Submit revised Hanford Site SAS Training Program Plan by April 30, 1996.

- 96-09 Complete Fiber Optic Sensor Implementation Plan by June 1, 1996. 


\begin{tabular}{|l|c|c|}
\hline \multicolumn{2}{|c|}{ COST ACCOUNT } & \multicolumn{2}{|c|}{$\begin{array}{c}\text { Westinghouse Hanford Company } \\
\text { Safeguards and Security } \\
\text { Work Breakdown } \\
\begin{array}{l}\text { Structure } \\
\text { Dictionary }\end{array}\end{array}$} & Part II - Element Definition & Revision \#0 \\
\hline
\end{tabular}

WBS ELEMENT CODE: 6.6 .3 .1

TITLE: Technical Support Services

ELEMENT TASK DESCRIPTION

MILESTONES (continued):

- 96-12 Submit SAS Distance Learning Resource Utilization Implementation Plan by July 1, 1996.

- 96-13 Complete Spread Spectrum Communication Implementation Plan by August 1, 1996.

\section{DELIVERABLES:}

- Fiber Optic Sensor Implementation PIan.

- Spread Spectrum Communication Implementation Plan.

- Hanford SAS Training Advisory Council meeting minutes.

- Revised Hanford Site SAS Training Program Plan.

- SAS Distance Learning Resource Utilization Implementation Plan. 


\begin{tabular}{|c|c|c|c|c|c|}
\hline \multirow{6}{*}{$\begin{array}{l}\text { Work } \\
\text { Breakdown } \\
\text { Structure } \\
\text { Dictionary }\end{array}$} & \multirow{6}{*}{\multicolumn{3}{|c|}{$\begin{array}{c}\text { Westinghouse Hanford Company } \\
\text { Safeguards and Security } \\
\text { Part I - Summary } \\
\text { (Dollars in 000's) }\end{array}$}} & \multirow{8}{*}{$\begin{array}{l}\text { FY } 1996 \text { SSPP } \\
\text { Rev. \# } 0\end{array}$} & Funding Source: \\
\hline & & & & & G\&A \\
\hline & & & & & sws \\
\hline & & & & & OST \\
\hline & & & & & \begin{tabular}{|l}
$\mathrm{DOH}$ \\
\end{tabular} \\
\hline & & & & & MGT PRO \\
\hline Cost Account & \multirow{2}{*}{\multicolumn{3}{|c|}{$\begin{array}{l}\text { Cost Account Title } \\
\text { SWS - Penformance Testing and Surveys }\end{array}$}} & & \multirow{2}{*}{\begin{tabular}{|l|} 
POOL \\
DIRECT
\end{tabular}} \\
\hline 1MOB0A0101 & & & & & \\
\hline $\begin{array}{l}\text { SMS WBS } \\
\end{array}$ & \multicolumn{3}{|c|}{ SWS - Performance Testing and Surveys } & \multirow{2}{*}{\multicolumn{2}{|c|}{$\begin{array}{c}\text { Annualized Rate } \\
\text { (For Organizational Overhead and } \\
\text { Rated Service Pool Use Only) }\end{array}$}} \\
\hline CAM Review/Approval & \multicolumn{2}{|r|}{ C.W. Walton } & Date & & \\
\hline \multicolumn{2}{|l|}{ SMS Program Manager Review/Approval } & C.W. Walton & Date & FY 1995 Rate & FY 1996 Rate Request \\
\hline \multicolumn{2}{|l|}{ Financial Manager Review/Approval } & F.D. Lé & Date & $-N / A-$ & $-N / A-$ \\
\hline \multicolumn{2}{|l|}{ Responsible Analyst } & L.V. Jones & Date & FY 1996 Target Rate & FY 1996 Approved Rate \\
\hline \multicolumn{3}{|l|}{ OSBRB Review/Approval } & Date & $-N / A-$ & $-N / A-$ \\
\hline & FY19 & & & FY 1996 & \\
\hline$\frac{\$}{\text { FULL-TIME EQUIVALENTS (FTES) }}$ & Budget & $\begin{array}{c}\text { Fiscal Year Spending } \\
\text { Forecast (FYSF) }\end{array}$ & Target & Request & $\begin{array}{l}\text { Approved } \\
\text { Baseline }\end{array}$ \\
\hline Organizational - Exempt & 2.3 & & & 2.0 & \\
\hline . Organizational - Nonexempt & 0.1 & & & 0.2 & \\
\hline . Organizational - Bargaining & & & & & \\
\hline Total Organizational FTEs & 2.4 & & & 2.2 & \\
\hline Support FTEs & & & & & \\
\hline TOTALFTES & 2.4 & $!$ & & 2.2 & \\
\hline 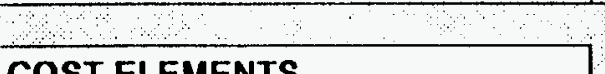 & & & & & \\
\hline $\begin{array}{l}\text { COST ELEMENTS } \\
\text {. Labor - Regular }\end{array}$ & 154 & & & 154 & \\
\hline . Labor - Overtime & & & & & \\
\hline 0 Total Labor & 154 & & & 154 & \\
\hline 1 Materials & 3 & & & 3 & \\
\hline 2 Purchased Senices & 139 & & & 125 & \\
\hline 3 Other Hanford & & & & & \\
\hline 4 Site Senvices & 11 & & & 9 & \\
\hline 5 Internal Charges & & & & & \\
\hline 6 IRM Support & 2 & & & 2 & \\
\hline 7 Overheads & 64 & & & 41 & \\
\hline 8 Revenue & & & & & \\
\hline TOTALDOLLARS & 373 & Prepared at CAP Level & & 334 & \\
\hline
\end{tabular}


COST ACCOUNT

\begin{tabular}{l|}
\hline $\begin{array}{l}\text { Work Breakdown } \\
\text { Structure } \\
\text { Dictionary }\end{array}$ \\
\hline
\end{tabular}

Westinghouse Hanford Company

FY 1996 SSPP

Safeguards and Security

Part II - Element Definition

Revision \#0

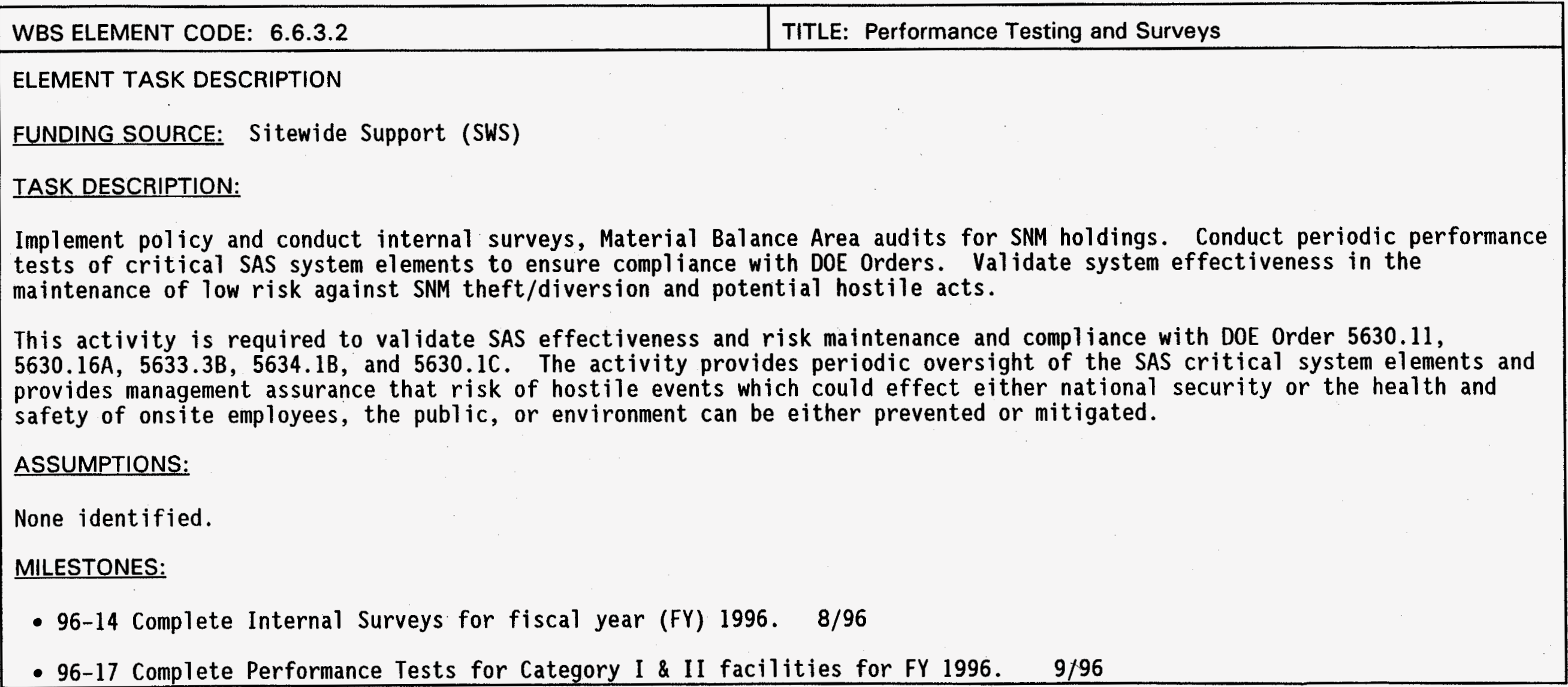




\begin{tabular}{|l|c|c|}
\hline \multicolumn{1}{|c|}{ COST ACCOUNT } & \multicolumn{2}{|c|}{ FY 1996 SSPP } \\
\hline $\begin{array}{l}\text { Work Breakdown } \\
\text { Structure } \\
\text { Dictionary }\end{array}$ & Westinghouse Hanford Company & Safeguards and Security \\
\hline
\end{tabular}

\begin{tabular}{|l|l|}
\hline WBS ELEMENT CODE: 6.6 .3 .2 & TITLE: Performance Testing and Surveys \\
\hline ELEMENT TASK DESCRIPTION \\
DELIVERABLES: \\
- Survey Reports - summarizing internal survey results. $8 / 96$ \\
- Performance Tests summary report. $9 / 96$ \\
- Validation of Internal and DOE Richland Operations Office (RL) Survey Findings - as required. \\
\end{tabular}




\begin{tabular}{|c|c|c|c|c|c|}
\hline \multirow{6}{*}{$\begin{array}{l}\text { Work } \\
\text { Breakdown } \\
\text { Structure } \\
\text { Dictionary }\end{array}$} & \multirow{6}{*}{\multicolumn{3}{|c|}{$\begin{array}{c}\text { Westinghouse Hanford Company } \\
\text { Safeguards and Security } \\
\text { Part I - Summary } \\
\text { (Dollars in } 000^{\prime} \text { s) }\end{array}$}} & \multirow{8}{*}{$\begin{array}{l}\text { FY } 1996 \text { SSPP } \\
\text { Rev. \# } 0\end{array}$} & Funding Source: \\
\hline & & & & & G\&A \\
\hline & & & & & sws \\
\hline & & & & & OST \\
\hline & & & & & $\mathrm{DOH}$ \\
\hline & & & & & MGT PRO \\
\hline \multirow{2}{*}{$\begin{array}{l}\text { Cost Account } \\
\text { 1MDBOA4301 }\end{array}$} & \multirow{2}{*}{\multicolumn{3}{|c|}{$\begin{array}{l}\text { Cost Account Title } \\
\text { SWS - Radiological/Toxicological Vulnerabillty Assessment/Risk Analysis }\end{array}$}} & & POOL \\
\hline & & & & & DIRECT \\
\hline $\begin{array}{ll}\text { SMS WBS } & \\
\end{array}$ & \multicolumn{3}{|c|}{$\begin{array}{l}\text { SMS Title } \\
\text { SWS - Radiological/Toxicologlcal Vulnerability Assessment/Risk Analysis }\end{array}$} & \multirow{2}{*}{\multicolumn{2}{|c|}{$\begin{array}{c}\text { Annualized Rate } \\
\text { (For Organizational Overhead and } \\
\text { Rated Service Pool Use Only) }\end{array}$}} \\
\hline CAM Review/Approval & \multicolumn{2}{|r|}{ C.W. Walton } & $\begin{array}{l}\text { Date } \\
\end{array}$ & & \\
\hline \multicolumn{2}{|l|}{ SMS Program Manager Review/Approval } & C.W. Walton & Date & FY 1995 Rate & FY 1996 Rate Request \\
\hline \multicolumn{2}{|l|}{ Financial Manager Revlew/Approval } & F.D. Lee & Date & $-N / A-$ & $-N / A-$ \\
\hline \multicolumn{2}{|l|}{ Responsible Analyst } & L.V. Jones & Date & FY 1996 Target Rate & FY 1996 Approved Rate \\
\hline \multirow[t]{3}{*}{ OSBRB Review/Approval } & & & Date & $-N / A-$ & $-N / A-$ \\
\hline & \multicolumn{2}{|c|}{ FY1995 } & \multicolumn{3}{|c|}{ FY 1996} \\
\hline & Budget & $\begin{array}{c}\text { Fiscal Year Spending } \\
\text { Forecast (FYSF) }\end{array}$ & Target & Request & $\begin{array}{l}\text { Approved } \\
\text { Baseline }\end{array}$ \\
\hline Organizational - Exempt & 2.8 & & & 2.0 & \\
\hline Organizational - Nonexempt & 0.3 & & & 0.2 & \\
\hline \multicolumn{6}{|l|}{ - Organizational - Bargaining } \\
\hline Total Organizational FTEs & 3.1 & & & 2.2 & \\
\hline \multicolumn{6}{|l|}{ Support FTES } \\
\hline TOTALFTES & 3.1 & & & 3.2 & \\
\hline \multicolumn{6}{|l|}{ COST ELEMENTS } \\
\hline . Labor - Regular & 194 & & & 226 & \\
\hline \multicolumn{6}{|l|}{ Labor - Overtime } \\
\hline 0 Total Labor & 195 & & & 226 & \\
\hline 1 Materials & & & & & \\
\hline 2 Purchased Services & & & & $\dot{2}$ & \\
\hline 3 Other Hanford & & & & & \\
\hline 4 Site Services & & & & & \\
\hline 5 Internal Charges & & & & & \\
\hline 6 IRM Support & & & & 9 & \\
\hline 7 Overheads & 81 & $\cdot$ & & 60 & \\
\hline 8 Revenue & & & & & \\
\hline TOTAL DOLLARS & 276 & Prepared at CAP Level & & 295 & \\
\hline
\end{tabular}


COST ACCOUNT

\section{Work Breakdown}

Structure

Dictionary
Westinghouse Hanford Company

Safeguards and Security

Part II - Element Definition

\section{FY 1996 SSPP}

Revision \#0

\begin{tabular}{|l|l}
\hline WBS ELEMENT CODE: 6.6 .3 .3 & TITLE: Radiological/Toxicological VA/Risk Analysis
\end{tabular}

\section{ELEMENT TASK DESCRIPTION}

FUNDING SOURCE: Sitewide Support (SWS)

\section{TASK DESCRIPTION:}

Conduct vulnerability assessment (VA) and risk analysis of identified radiological and toxicological interests on the Hanford Site as required. Risk analysis is required by DOE 5630.11B and DOE RLID 5630.3A, to ensure that impacts from potential hostile acts are identified and either mitigated or protected if the risk is unacceptable. Nineteen facilities and locations have been identified by Emergency Preparedness Hazards Assessments. Eight have been completed or are projected for completion in FY 1995. Six are identified for completion in FY 1996. The objective is to identify consequence/risk issues that could affect employee or public health/safety from a hostile event, and if risk is unacceptable, identify mitigating or cost-effective prevention strategies.

\section{ASSUMPTIONS:}

None identified.

\section{MILESTONES:}

- 96-19 Complete six VAs/Risk Analysis per Hanford Site Integrated Schedule. 


\begin{tabular}{|l|c|c|}
\hline \multicolumn{2}{|c|}{ COST ACCOUNT } & \multicolumn{2}{|c|}{} \\
\hline $\begin{array}{l}\text { Work Breakdown } \\
\text { Structure } \\
\text { Dictionary }\end{array}$ & $\begin{array}{c}\text { Westinghouse Hanford Company } \\
\text { Safeguards and Security } \\
\text { Part II - Element Definition }\end{array}$ & FY 1996 SSPP \\
\hline
\end{tabular}

WBS ELEMENT CODE: $\quad 6 \cdot 6.3 .3$

TITLE: Radiological/Toxicological VA/Risk Analysis

ELEMENT TASK DESCRIPTION

DELIVERABLES:

- VA/Risk Analysis reports for the following:

- 324/308/325 Buildings

- PUREX

- 222-S Building

- 300 Area General $(303,306 \mathrm{E}, 3717,3718 \mathrm{M}, 3712,3766,313,333,340$ Complex, 329, 318 \& LERF)

- $\mathrm{UO}_{3}$ and U PI ant (221-U)

- WSCF Laboratory \& 200 Area Water Treatment Facility 


\section{Work \\ Breakdown \\ Structure \\ Dictionary}

\begin{tabular}{|c|c|}
\hline \multicolumn{2}{|c|}{$\begin{array}{c}\text { Cost Account } \\
\text { 1MDBOA4302 }\end{array}$} \\
\hline SMS WBS $\quad 6.6 .3 .4$ & SM \\
\hline
\end{tabular}

\section{CAM Review/Approval}

SMS Program Manager Review/Approval

Financlal Manager Review/Approval

Responsible Analyst

OSBRB Review/Approval

\begin{tabular}{l}
1.19 \\
FULL-TIME EQUIVALENTS (FTEs) \\
\hline Organizational - Exempt \\
\hline Organizational - Nonexempt \\
\hline Organizational - Bargaining \\
\hline Total Organizational FTEs \\
\hline Support FTEs \\
\hline TOTALFTES \\
\hline
\end{tabular}

\section{COST ELEMENTS}

. Labor - Regular

. Labor - Overtime

0 Total Labor

1 Materlals

2 Purchased Services

3 Other Hanford

4 Site Services

5 Internal Charges

6 IRM Support

7 Overheads

8 Revenue

TOTAL DOLLARS

46

46

$+$
Cost Account Title

SMS Title

sWS - Site Safeguards and Security Plan

SWS - Site Safeguards and Security Plan

Safeguards and Security

Part I - Summary

(Dollars in 000's)

\begin{tabular}{|cc|}
\hline & \multicolumn{2}{c}{ SWS - Site Safeguards and Security Plan } \\
\hline C.W. Walton & Date \\
\hline C.W. Walton & Date \\
\hline F.D. Lee & Date \\
\hline L.V. Jones & Date \\
\hline & Date
\end{tabular}

\begin{tabular}{|rr|l|}
\hline \multicolumn{3}{|c|}{ FY1995 } \\
\hline & & $\begin{array}{c}\text { Fiscal Year Spending } \\
\text { Forecast (FYSF) }\end{array}$ \\
\hline & 0.6 & \\
\hline & 0.2 & \\
\hline & 0.8 & \\
\hline & 0.8 & \\
\hline
\end{tabular}

Target
Westinghouse Hanford Company

FY 1996 SSPP

Rev. \# 0

G\&A

SWS

OST

$\mathrm{DOH}$

MGT PRO

POOL

DIRECT

Annualized Rate

(For Organizational Overhead and Rated Service Pool Use Only)

FY 1995 Rate $\quad$ FY 1996 Rate Request

$-N / A-$

FY 1996 Target Rate FY 1996 Approved Rate

-N/A-

FY 1996

\begin{tabular}{|ll|l|l|}
\hline Request & $\begin{array}{c}\text { Approved } \\
\text { Baseline }\end{array}$ \\
\hline 0.5 & 0.2 & \\
\hline & 0.7 & \\
\hline 0.7 & & \\
\hline
\end{tabular}

44

\begin{tabular}{|r|r|}
\hline 46 & \\
\hline & \\
\hline & \\
\hline & \\
\hline 18 & \\
\hline 19 & \\
\hline 83 & Prepared at CAP Level \\
\hline
\end{tabular}

44 


\begin{tabular}{|c|c|c|c|c|c|}
\hline \multirow{6}{*}{$\begin{array}{l}\text { Work } \\
\text { Breakdown } \\
\text { Structure } \\
\text { Dictionary }\end{array}$} & \multirow{6}{*}{\multicolumn{3}{|c|}{$\begin{array}{c}\text { Westinghouse Hanford Company } \\
\text { Safeguards and Security } \\
\text { Part I - Summary } \\
\text { (Dollars in 000's) }\end{array}$}} & \multirow{8}{*}{$\begin{array}{l}\text { FY } 1996 \text { SSPP } \\
\text { Rev. } \# 0\end{array}$} & Funding Source: \\
\hline & & & & & G\&A \\
\hline & & & & & sws \\
\hline & & & & & OST \\
\hline & & & & & $\mathrm{DOH}$ \\
\hline & & & & & MGT PRO \\
\hline Cost Account & Cost Account Title & & & & \multirow{2}{*}{\begin{tabular}{|l|} 
POOL \\
DIRECT \\
\end{tabular}} \\
\hline 1MDBOA4302 & \multicolumn{3}{|c|}{ SWS - Threat Evaluation } & & \\
\hline \begin{tabular}{|l|} 
SMS WBS \\
\end{tabular} & \multicolumn{3}{|c|}{ SwS - Threat Evaluation } & \multirow{2}{*}{\multicolumn{2}{|c|}{$\begin{array}{c}\text { Annualized Rate } \\
\text { (For Organizational Overhead and } \\
\text { Rated Service Pool Use Only) }\end{array}$}} \\
\hline CAM Review/Approval & \multicolumn{3}{|c|}{ C.W. Walton Date } & & \\
\hline \multicolumn{2}{|l|}{ SMS Program Manager Review/Approval } & C.W. Walton & Date & FY 1995 Rate & FY 1996 Rate Request \\
\hline \multicolumn{2}{|l|}{ Financial Manager Revlew/Approval } & F.D. Le日 & Date & $-N / A-$ & $-N / A-$ \\
\hline \multicolumn{2}{|l|}{ Responsible Analyst } & L.V. Jones & Date & FY 1996 Target Rate & FY 1996 Approved Rate \\
\hline \multicolumn{3}{|l|}{ OSBRB Review/Approval } & Date & $-N / A-$ & $-N / A-$ \\
\hline & \multicolumn{2}{|c|}{ FY1995 } & \\
\hline FULL-TIME EQUIVALENTS (FTES) & Budget & \begin{tabular}{|c|} 
Fiscal Year Spending \\
Forecast (FYSF)
\end{tabular} & Target & Request & $\begin{array}{l}\text { Approved } \\
\text { Baseline }\end{array}$ \\
\hline . Organizational - Exempt & 0.5 & & & 0.5 & \\
\hline . Organizational - Nonexempt & 0.1 & & & 0.1 & \\
\hline \multicolumn{6}{|l|}{ Organizational - Bargaining } \\
\hline Total Organizational FTEs & 0.6 & & & 0.6 & \\
\hline \multicolumn{6}{|l|}{ Suppont FTEs } \\
\hline TOTALFTES & 0.6 & tis & & 0.6 & \\
\hline$\frac{4,4 \%}{\text { COST FI FMFNTS }}$ & & & & & \\
\hline \begin{tabular}{|l} 
COST ELEMENTS \\
. Labor - Regular
\end{tabular} & 34 & & & 40 & \\
\hline . Labor - Overtime & & & & & \\
\hline 0 Total Labor & 34 & & & 40 & \\
\hline 1 Materials & & & & & \\
\hline 2 Purchased Senices & & & & & \\
\hline 3 Other Hanford & & & & & \\
\hline 4 Site Senvices & & & & & \\
\hline 5 Internal Charges & & & & & \\
\hline 6 IRM Support & 3 & & & 2 & \\
\hline 7 Overheads & 14 & & & 11 & \\
\hline 8 Revenue & & & & & \\
\hline TOTALDOLLARS & 51 & Prepared at CAP Level & & 53 & \\
\hline
\end{tabular}




\begin{tabular}{|l|c|c|}
\hline \multicolumn{1}{|c|}{ COST ACCOUNT } & \multicolumn{2}{|c|}{ FY 1996 SSPP } \\
\hline $\begin{array}{l}\text { Work Breakdown } \\
\text { Structure } \\
\text { Dictionary }\end{array}$ & Westinghouse Hanford Company & Safeguards and Security \\
\hline
\end{tabular}

WBS ELEMENT CODE: 6.6 .3 .5
ELEMENT TASK DESCRIPTION
FUNDING SOURCE: Sitewide Support (SWS)
TASK DESCRIPTION:
Provide technical support in revising and developing risk analysis methodology. Develop a method that provides a
Capability for a management mitigation factor that would be applied to adjust base case risk.
If eliminated no analysis of the DOE threat policy would take place. This could allow unacceptable rad/tox sabotage and
potential theft of SNM risks.
ASSUMPTIONS:
- Mitigation can be quantified using expert judgment.
Some conditions that may impact risk include: facility remoteness, safety and emergency systems target attractiveness,
recovery capability, and target task difficuity.


COST ACCOUNT

Work Breakdown

Structure

Dictionary

WBS ELEMENT CODE: $\quad$ 6.6.3.5

ELEMENT TASK DESCRIPTION

MILESTONES:

None identified.

DELIVERABLES:

- Internal Pubiication of Threat Evaluations - 4/96
FY 1996 SSPP

Revision \#0
Safeguards and Security

Part II - Element Definition

TITLE: Threat Evaluation 


\begin{tabular}{|c|c|c|c|c|c|}
\hline \multirow{6}{*}{$\begin{array}{l}\text { Work } \\
\text { Breakdown } \\
\text { Structure } \\
\text { Dictionary }\end{array}$} & \multirow{6}{*}{\multicolumn{3}{|c|}{$\begin{array}{c}\text { Westinghouse Hanford Company } \\
\text { Safeguards and Security } \\
\text { Part I - Summary } \\
\text { (Dollars in 000's) }\end{array}$}} & \multirow{8}{*}{$\begin{array}{l}\text { FY } 1996 \text { SSPP } \\
\text { Rev. \# } 0\end{array}$} & \multirow{2}{*}{\begin{tabular}{|l} 
Funding Source: \\
G\&A \\
\end{tabular}} \\
\hline & & & & & \\
\hline & & & & & \begin{tabular}{|l|} 
SWS \\
\end{tabular} \\
\hline & & & & & OST \\
\hline & & & & & $\mathrm{DOH}$ \\
\hline & & & & & MGT PRO \\
\hline Cost Account & \multirow{2}{*}{\multicolumn{3}{|c|}{$\begin{array}{l}\text { Account Title } \\
\text { SWS - Industrial Security - Northern Area Engineering }\end{array}$}} & & \multirow{2}{*}{\begin{tabular}{|l|} 
POOL \\
DIRECT
\end{tabular}} \\
\hline 1MDBOA1B01 & & & & & \\
\hline $\begin{array}{cc}\text { SMS WBS } & \\
\end{array} \quad 6.6 .3 .6$ & \multicolumn{3}{|c|}{ sWS - Industrial Security - Northern Area Engineering } & \multirow{2}{*}{\multicolumn{2}{|c|}{$\begin{array}{l}\text { Annualized Rate } \\
\text { (For Organizational Overhead and } \\
\text { Rated Service Pool Use Only) }\end{array}$}} \\
\hline CAM Review/Approval & \multicolumn{2}{|c|}{ C.W. Walton } & Date & & \\
\hline \multicolumn{2}{|l|}{ SMS Program Manager Review/Approval } & C.W. Walton & Date & FY 1995 Rate & FY 1996 Rate Request \\
\hline \multicolumn{2}{|l|}{ Financial Manager Review/Approval } & F.D. Le日 & Date & $-N / A-$ & $-N / A-$ \\
\hline \multicolumn{2}{|l|}{ Responsible Analyst } & L.V. Jones & Date & FY 1996 Target Rate & FY 1996 Approved Rate \\
\hline \multicolumn{3}{|l|}{ OSBRB Review/Approval } & Date & $-N / A-$ & $-N / A-$ \\
\hline & FY19: & 95 & & FY 1996 & \\
\hline FULL-TIME EQUIVALENTS (FTES) & Budget * & $\begin{array}{c}\text { Fiscal Year Spending } \\
\text { Forecast (FYSF) }\end{array}$ & Target & Request & $\begin{array}{l}\text { Approved } \\
\text { Baseline }\end{array}$ \\
\hline . Organizational - Exempt & 1.2 & & & 0.4 & \\
\hline . Organizational - Nonexempt & 0.9 & & & 0.3 & \\
\hline . Organizational - Bargaining & & & & & \\
\hline Total Organizational FTEs & 2.1 & & & 0.7 & \\
\hline Support FTEs & & & & & \\
\hline TOTAL FTES & 2.1 & & & 0.7 & \\
\hline COST ELEMENTS & & & & & \\
\hline . Labor - Regular & 110 & & & 41 & \\
\hline . Labor - Overtime & & & & & \\
\hline 0 Total Labor & 110 & & & 41 & \\
\hline 1 Materials & 13 & & & 2 & \\
\hline 2 Purchased Services & 4 & & & 2 & \\
\hline 3 Other Hanford & 4 & & & 3 & \\
\hline 4 Site Services & 4 & & & 0 & \\
\hline 5 Internal Charges & & & & & \\
\hline 6 IRM Support & 7 & & & & \\
\hline 7 Overheads & 46 & & & 11 & \\
\hline 8 Revenue & & & & & \\
\hline TOTAL DOLLARS & 188 & Prepared at CAP Level & & 59 & \\
\hline
\end{tabular}

* FY 95 budget includes SWS - Industrial Security - Northern Operations (SMS 6.6.3.7). FY 96 budget is now shown as a discrete task. 
COST ACCOUNT

\begin{tabular}{|l|c|}
\hline $\begin{array}{l}\text { Work Breakdown } \\
\text { Structure } \\
\text { Dictionary }\end{array}$ & Westinghouse Hanford Company \\
Safeguards and Security \\
Part II - Element Definition
\end{tabular}

WBS ELEMENT CODE: 6 6. 6.3 .6

TITLE: Northern Area Industrial Security Engineering

\section{ELEMENT TASK DESCRIPTION}

FUNDING SOURCE: Sitewide Support (SWS)

\section{TASK DESCRIPTION:}

This workscope provides nonprogram-specific security system engineering/maintenance and staff support for facilities in the 200 East, 200 West, 100 , and 600 Areas that do NOT store Category I or II SNM. Such facilities include Tank Farms, Solid Waste, B Plant, and PUREX.

Elimination of this task would cut support to the referenced facilities. Such support includes design reviews,

sensor/camera installation and maintenance, and research and administrative support for waivers, deviations, and survey findings/observations. Although these facilities do not store Category I or II SNM, they are subject to rad/tox sabotage security requirements. Without adequate protection, these facilities may present moderate or higher onsite and potentially offsite risks. Without engineering appropriate security systems, these facilities would have to rely solely on more expensive and recurring cost of Patrol protection.

\section{ASSUMPTIONS:}

- Industrial security requirements for sensors, cameras, and access control will increase in FY 1996 based on VAs aimed at asset protection, worker/public health, and safety. 


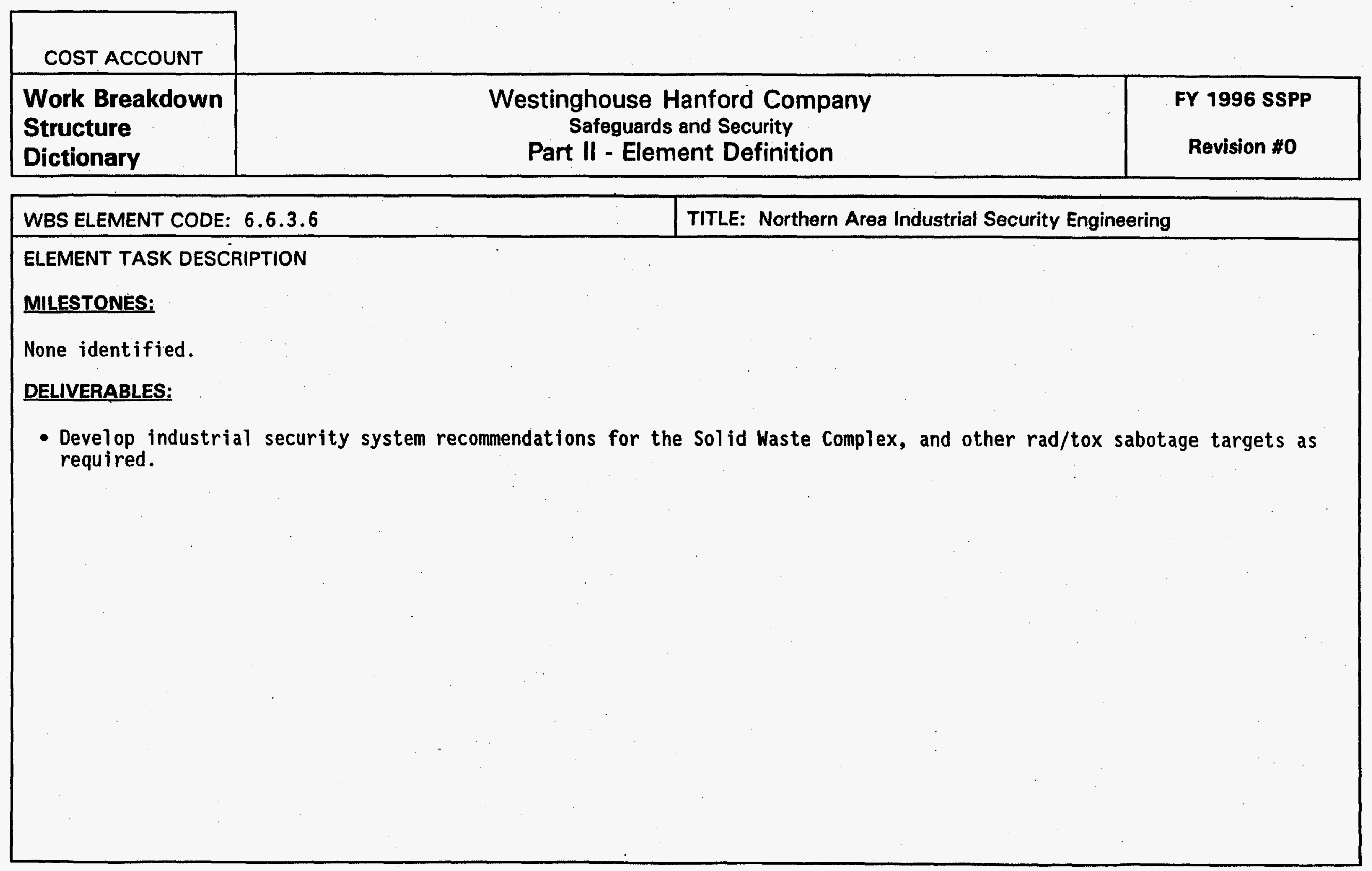

64 


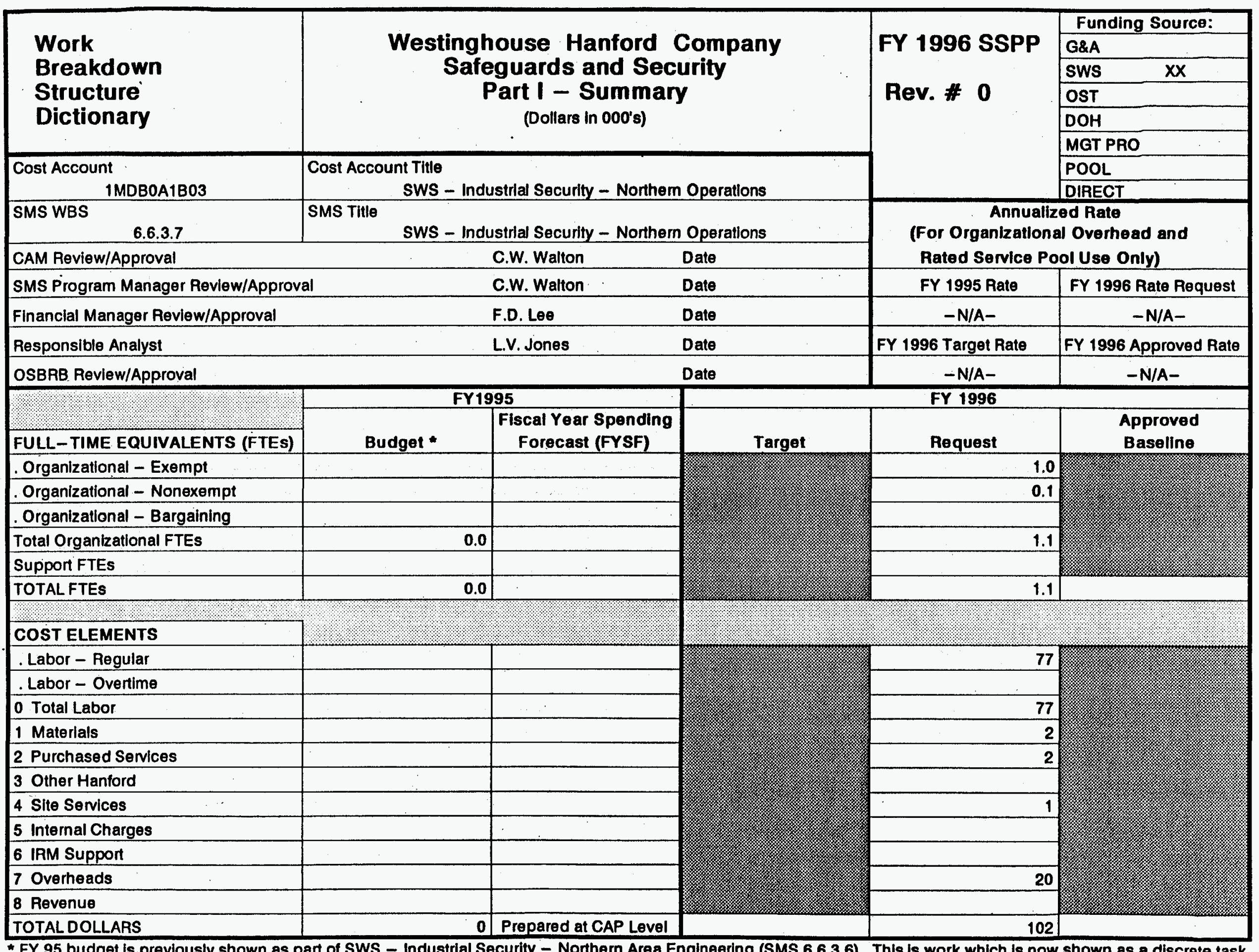

* FY 95 budget is previously shown as part of SWS - Industrial Security - Northern Area Engineering (SMS 6.6.3.6). This is work which is now shown as a discrete task.
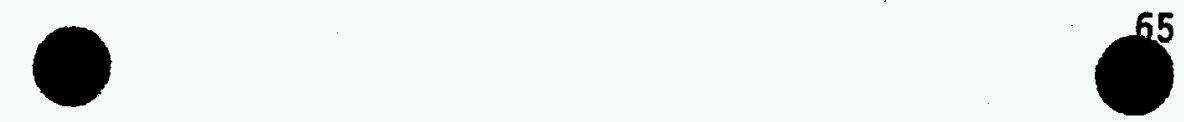


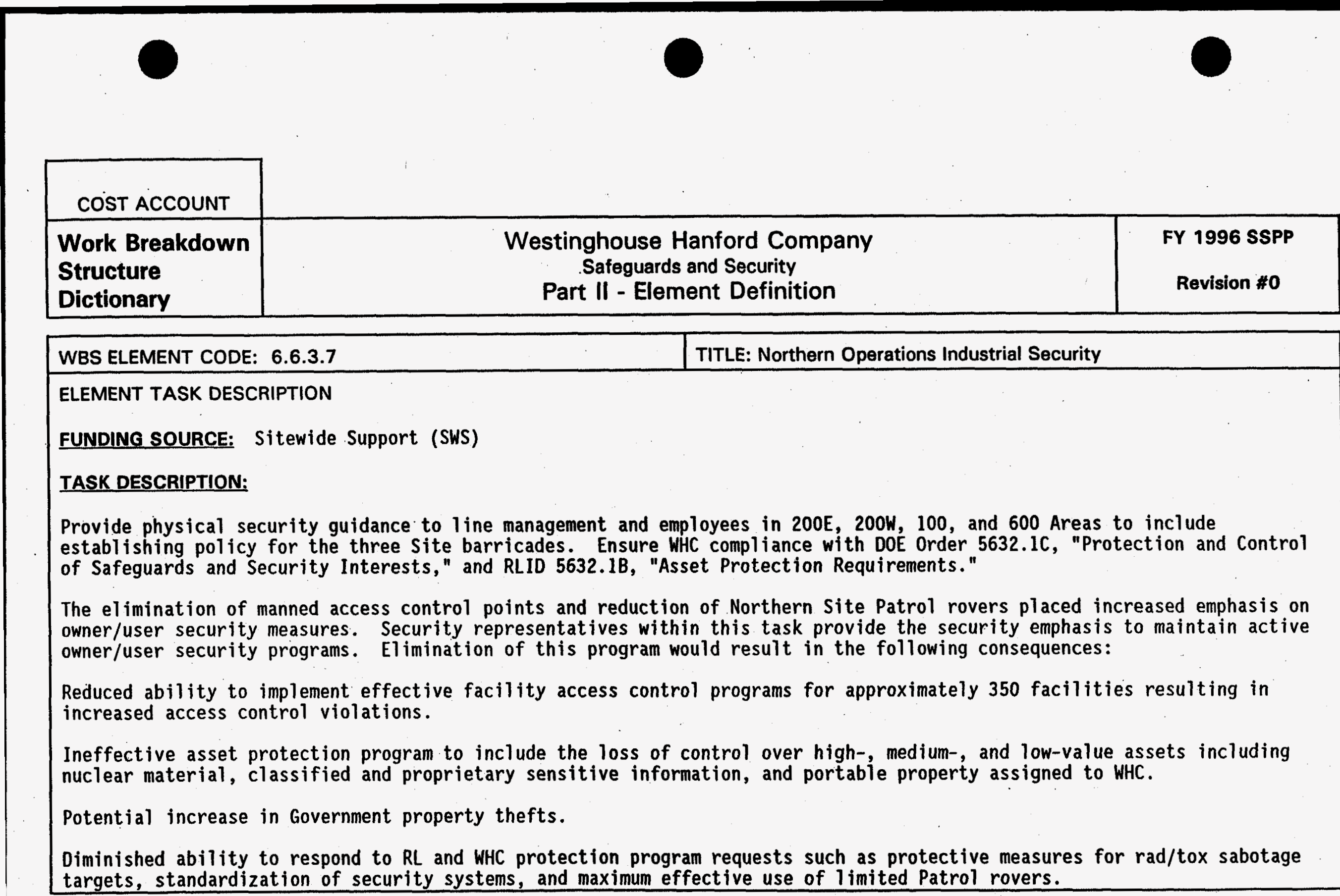




\section{Work Breakdown}

Structure

Dictionary

\section{Westinghouse Hanford Company}

Safeguards and Security

Part II - Element Definition
FY 1996 SSPP

Revision \#0

\begin{tabular}{|l|l|}
\hline WBS ELEMENT CODE: 6.6 .3 .7 & TITLE: Northern Operations Industrial Security \\
\hline
\end{tabular}

ELEMENT TASK DESCRIPTION

\section{ASSUMPTIONS:}

- The RLID asset protection program and asset protection agreements will continue. Facility protection must be arranged and maintained accordingly.

\section{MILESTONES:}

None identified.

DELIVERABLES:

- Provide comprehensive physical security program support for all northern area WHC facilities and industrial security needs, including security engineering, security key control, and educational support.

- Annual asset protection surveys.

- Administration of decentralized key control program.

- Review of unsecured building incidents and security violations. 


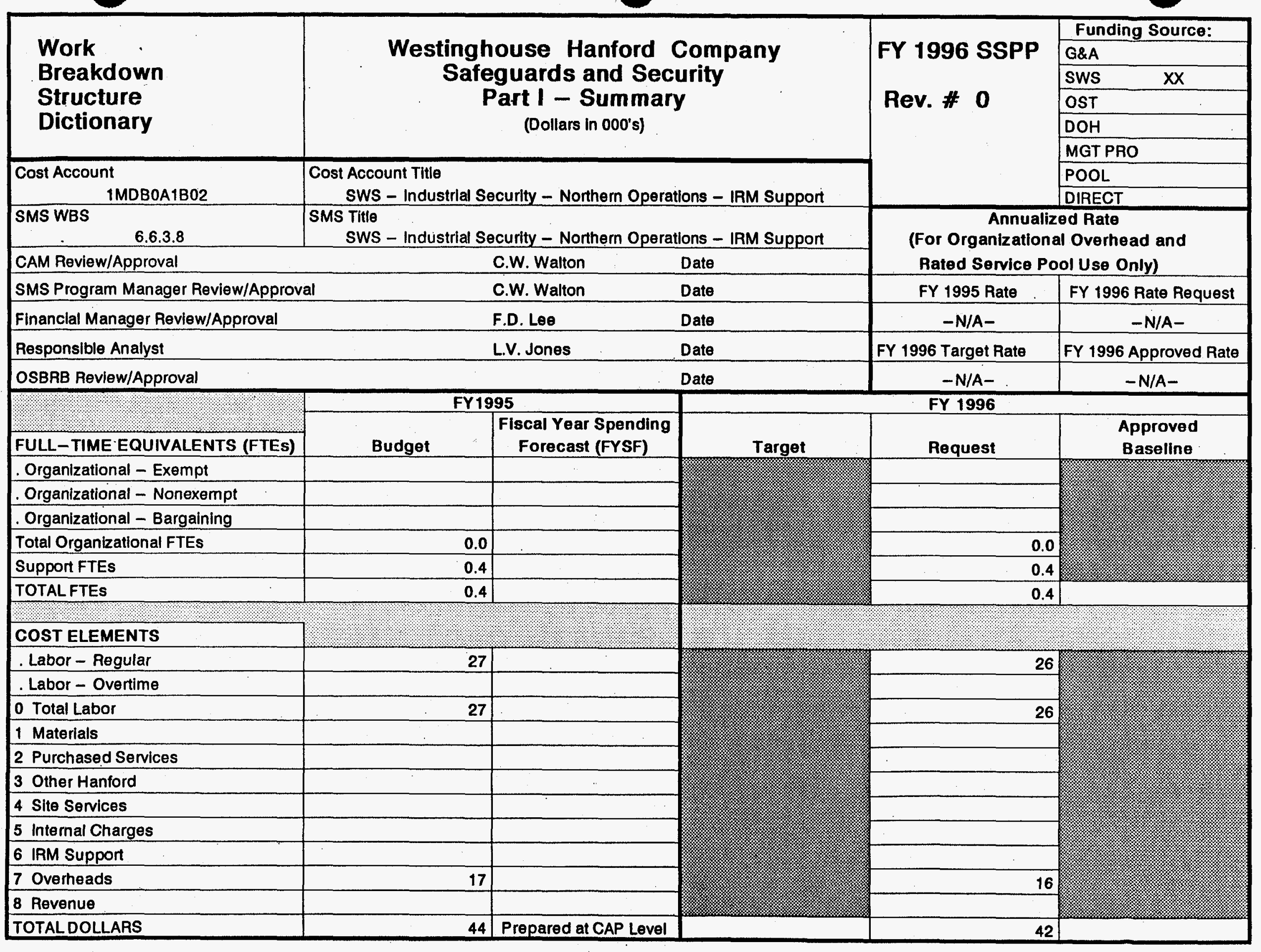


COST ACCOUNT

\begin{tabular}{|l|c|}
\hline $\begin{array}{l}\text { Work Breakdown } \\
\text { Structure } \\
\text { Dictionary }\end{array}$ & Westinghouse Hanford Company \\
Safeguards and Security \\
Part II - Element Definition
\end{tabular}

WBS ELEMENT CODE: $6 \cdot 6.3 .8$

TITLE: Northern Area Industrial Security IRM Support

ELEMENT TASK DESCRIPTION

FUNDING SOURCE: Sitewide Support (SWS)

\section{TASK DESCRIPTION:}

IRM provides software engineering support for the computer security systems of outer-area facilities which do NOT store Category I or II SNM.

The elimination of this task would cut computer system support/interface for security engineers. Without adequate security, these facilities may present moderate or higher rad/tox sabotage risks. Relying solely on Patrol protection would be less effective and more expensive than an automated security system.

\section{ASSUMPTIONS:}

- The computer based random search policy will be maintained to support the Patrol random search team.

- Implementation of DOE Order 5632.10 and Manual 5632.1C-1 will require changes to the existing physical security programs.

\section{MILESTONES:}

None identified. 


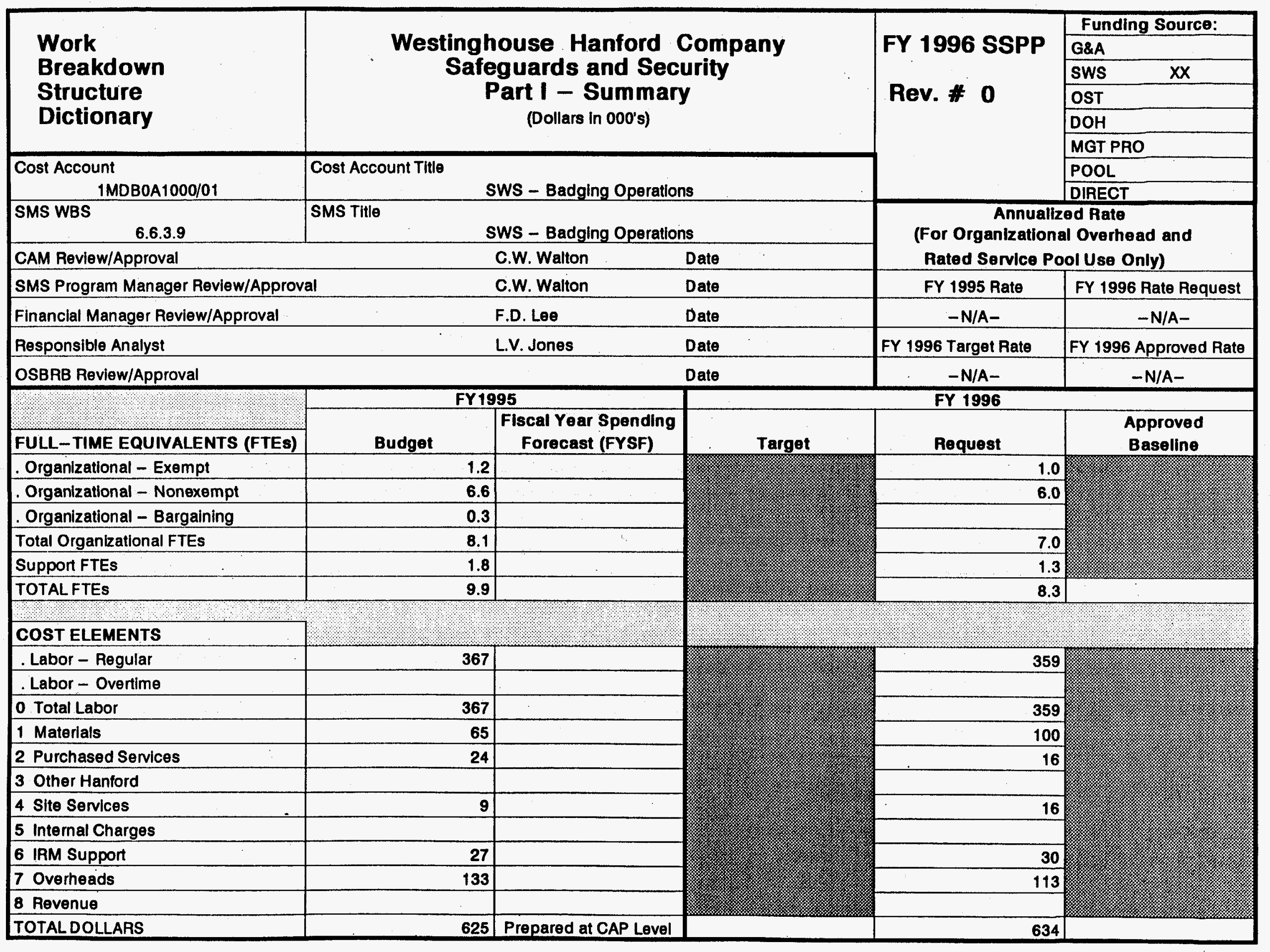


Work Breakdown

\section{Structure}

Dictionary
Westinghouse Hanford Company

Safeguards and Security

Part II - Element Definition
FY 1996 SSPP

Revision \#0

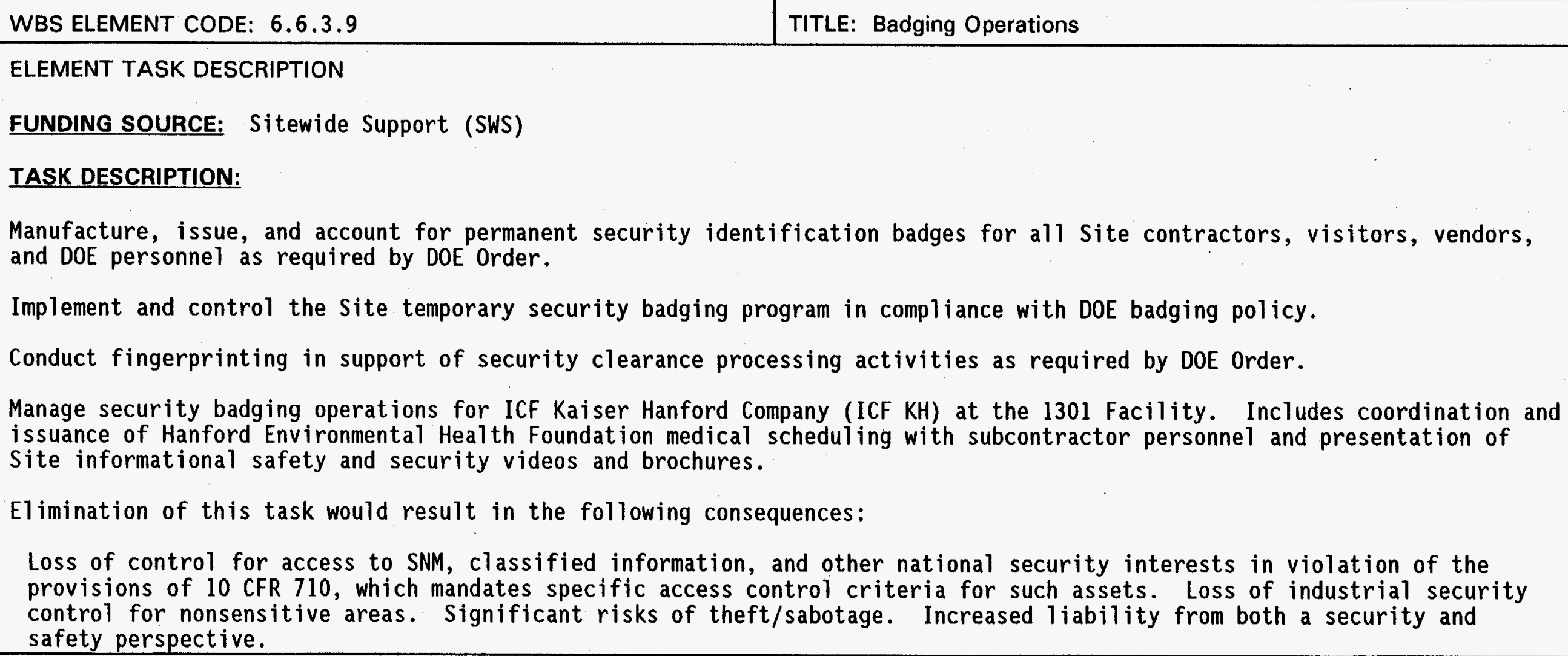




\begin{tabular}{|l|c|c|}
\hline \multicolumn{2}{|c|}{ COST ACCOUNT } & \multicolumn{2}{|c|}{ Festinghouse Hanford Company 1996 SSPP } \\
\hline $\begin{array}{l}\text { Work Breakdown } \\
\text { Structure } \\
\text { Dictionary }\end{array}$ & $\begin{array}{c}\text { Safeguards and Security } \\
\text { Part II - Element Definition }\end{array}$ & Revision \#0 \\
\hline
\end{tabular}

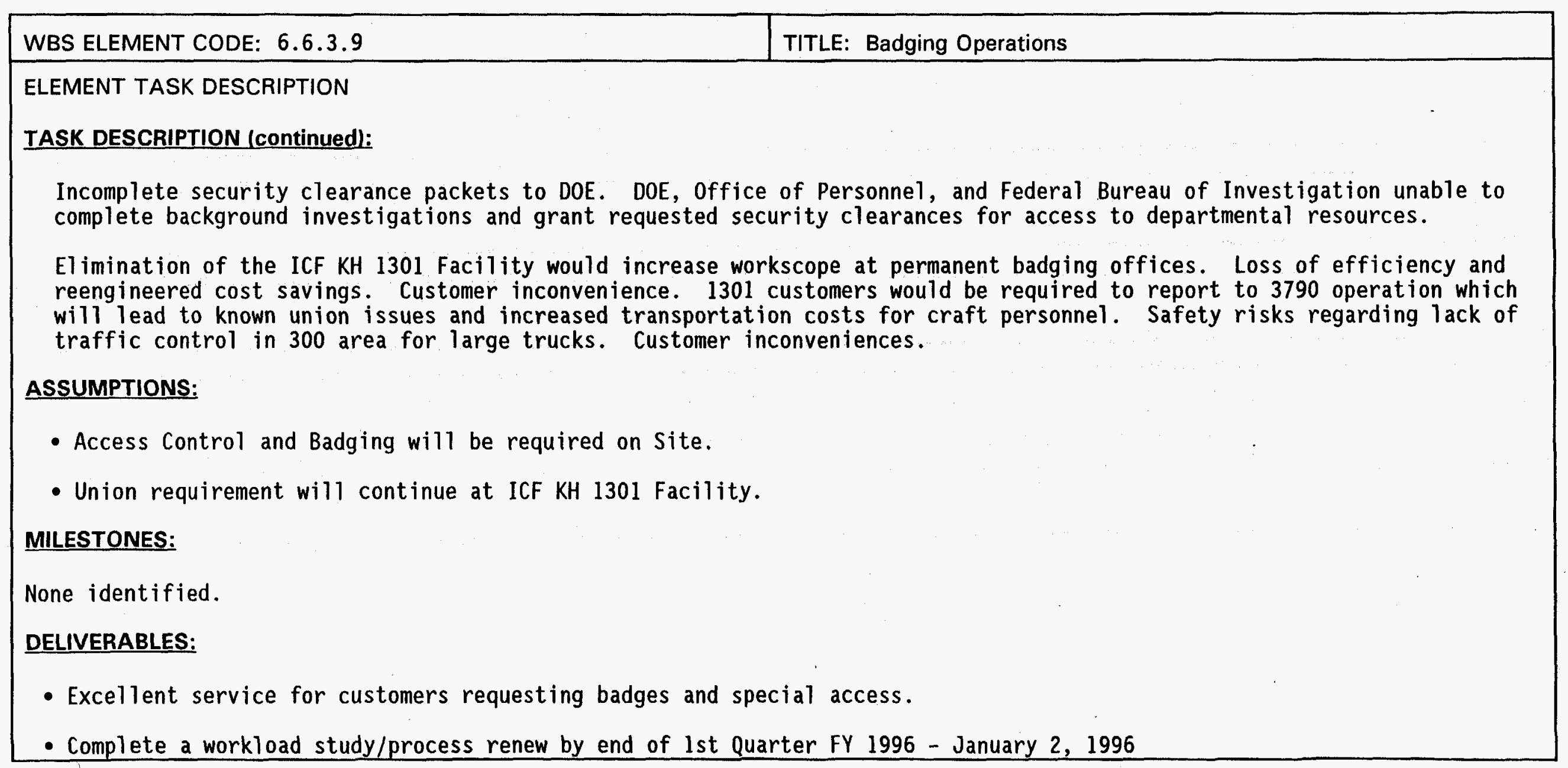




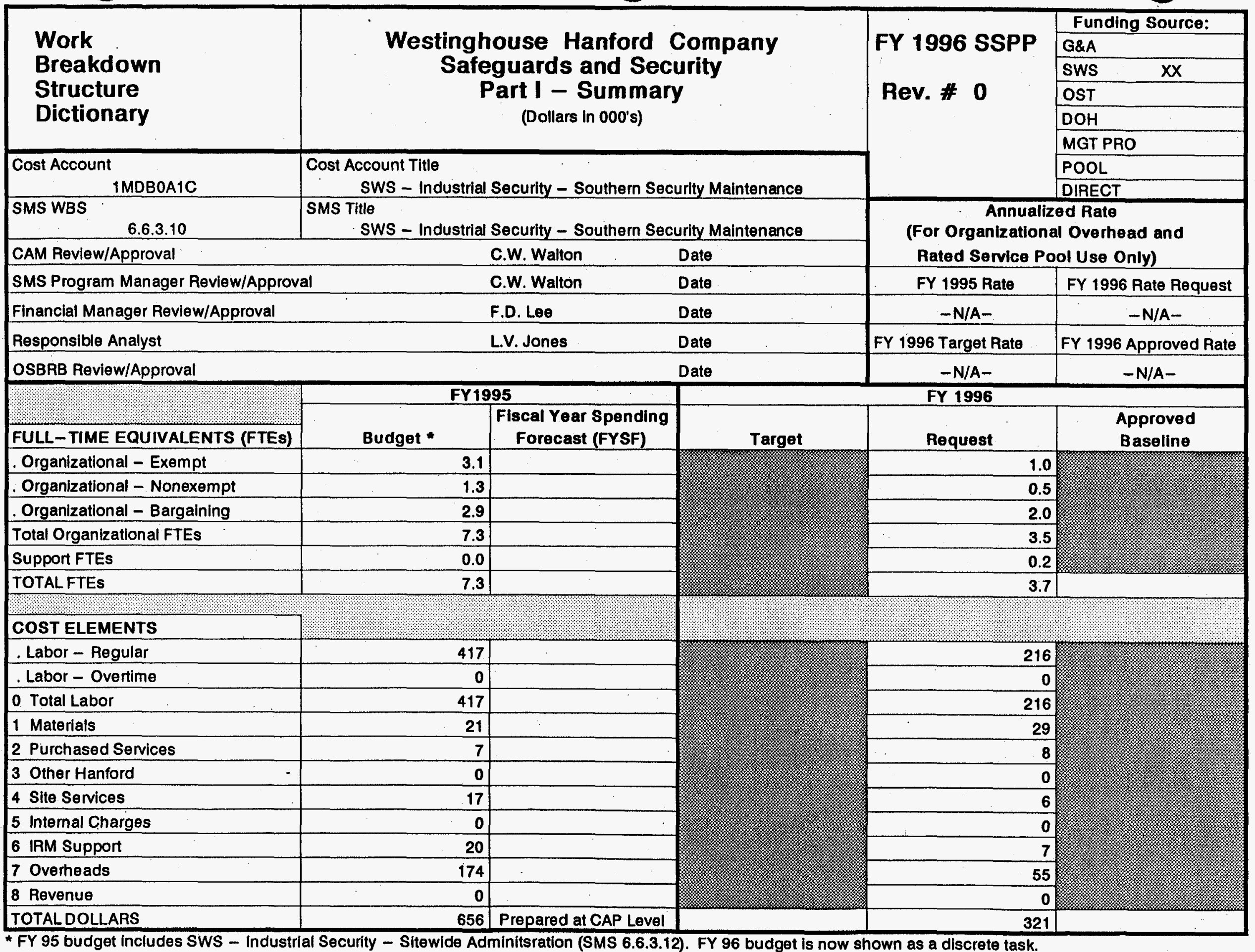




\begin{tabular}{|l|c|c|}
\hline \multicolumn{1}{|c|}{ COST ACCOUNT } & \multicolumn{2}{|c|}{} \\
\hline $\begin{array}{l}\text { Work Breakdown } \\
\text { Structure } \\
\text { Dictionary }\end{array}$ & $\begin{array}{c}\text { Westinghouse Hanford Company } \\
\text { Safeguards and Security } \\
\text { Part II - Element Definition }\end{array}$ & FY 1996 SSPP \\
\hline
\end{tabular}

WBS ELEMENT CODE: 6 6.6.3.10

TITLE: Southern Area Industrial Security (Security Maint.)

ELEMENT TASK DESCRIPTION

FUNDING SOURCE: Sitewide Support (SWS)

\section{TASK DESCRIPTION:}

Develop and implement a security systems maintenance and engineering program to ensure correct design, installation, and maintenance of approximately 12 access control systems, 122 security sensor systems, and 51 executive protection systems located in the Federal Office Building (FOB), 1163 Central Warehouse, 712 Classified Storage Vault, 1100 Jadwin, Stevens Center Complex, Patrol Training Academy, and selected Property Protection Area facilities.

Elimination of this program would result in the following consequences:

Loss of qualified engineering and maintenance support for existing access control and security systems resulting in diminished capability to control access to critical facilities and increased potential for the theft of government property.

Increased use of the more expensive and recurring cost of Patrol protection.

\section{ASSUMPTIONS:}

- Sustain and maximize operational security performance, through implementation of a compliance-based, cost-effective system maintenance and engineering program.

- Provide maintenance and engineering support for new DOE Orders and directives.

- Maintenance and engineering support will be provided to the security system testing program. 


\begin{tabular}{|l|c|c|}
\hline \multicolumn{2}{|c|}{ COST ACCOUNT } & \multicolumn{2}{|c|}{ FY 1996 SSPP } \\
\hline $\begin{array}{l}\text { Work Breakdown } \\
\text { Structure } \\
\text { Dictionary }\end{array}$ & $\begin{array}{c}\text { Westinghouse Hanford Company } \\
\text { Safeguards and Security } \\
\text { Part II - Element Definition }\end{array}$ & Revision \#0 \\
\hline
\end{tabular}

\begin{tabular}{|l|l|}
\hline WBS ELEMENT CODE: 6.6 .3 .10 & TITLE: Southern Area Industrial Security (Security Maint.) \\
\hline
\end{tabular}

\section{ELEMENT TASK DESCRIPTION}

ASSUMPTIONS (continued):

- Property Protection Areas and Limited Areas will be maintained as required.

- Engineering and craft work space will become more restrictive and geographically less functional.

- Engineering and craft requests will increase to support new automated entry control and security badging systems.

\section{MILESTONES:}

None identified.

\section{DELIVERABLES:}

- Provide timely engineering and maintenance response and completion of all priority work requests to include design, installation, and maintenance of new security systems.

- Develop, review, and complete preventive maintenance procedures.

- Ensure security systems and entry control device perform in compliance with DOE Orders, WHC policies and procedures through performance review and configuration control.

- Safely maintain a fully compliant hazardous waste satellite retention center. 


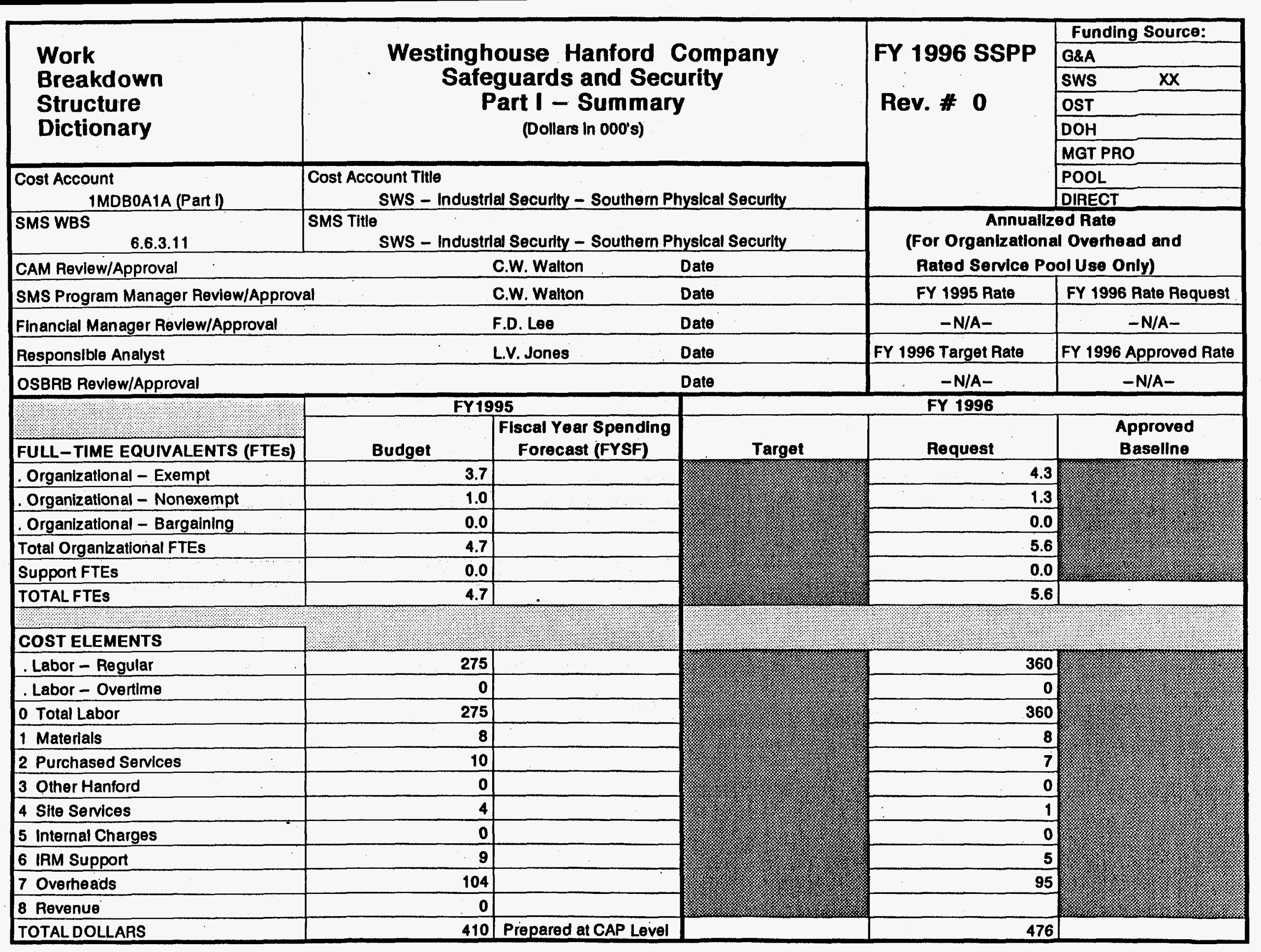





\section{Work Breakdown}

Structure

Dictionary
Westinghouse Hanford Company

Safeguards and Security

Part II - Element Definition

\section{FY 1996 SSPP}

Revision \#0

\begin{tabular}{|l|l|}
\hline WBS ELEMENT CODE: 6.6 .3 .11 & TITLE: Southern Area Industrial Security (Physical Security) \\
\hline
\end{tabular}

\section{ELEMENT TASK DESCRIPTION}

\section{TASK DESCRIPTION (continued):}

Elimination of this program would result in the following consequences:

Reduced ability to implement effective facility access control programs for approximately 300 facilities, resulting in increased unauthorized access violations.

Loss of control over high, medium and low assets, i.e., SNM/nuclear material, controlled substances, precious metals, firearms, classified matter, information, portable property, etc., assigned to WHC.

Potential increase in government property thefts. Property thefts FYTD for the referenced areas is approximately $100 \mathrm{~K}$.

Diminished ability to respond to RL and Company protection program requests, i.e., coordination of executive protection programs at 1100 Jadwin and the FOB, development and implementation of automated access control programs as installed in the FOB, 1163 Warehouse, and Stevens Center Complex; resulting in an increased utilization of Patrol personnel.

\section{ASSUMPTIONS:}

- Review and ensure implementation of new Orders, directives, and RLIDs.

- Maintain a standardized security systems testing program.

- Access control procedures will be revised to reflect changing mission and/or order requirements. 
COST ACCOUNT

Work Breakdown

Structure

Dictionary
Westinghouse Hanford Company

Safeguards and Security

Part II - Element Definition
FY 1996 SSPP

Revision \#0

WBS ELEMENT CODE: 6.6 .3 .11

TITLE: Southern Area Industrial Security (Physical Security)

ELEMENT TASK DESCRIPTION

ASSUMPTIONS (continued):

- Property Protection Areas and Limited Areas will be maintained.

- The computer-based random search policy will be maintained to support the Patrol random search team.

MILESTONES:

None identified.

DELIVERABLES:

- Provide Site facilities security evaluation reviews to ensure facility compliance with Asset Protection Agreements.

- Support the development of Hanford security interest maps to document locations of security interests and Limited Areas. 


\section{Work \\ Breakdown \\ Structure \\ Dictionary}

\section{Cost Account}

SMS WBS

1MDBOA1A (Part II)

6.6.3.12

CAM Review/Approval

SMS Program Manager Review/Approval

Financial Manager Review/Approval

Responsible Analyst

OSBRB Review/Approval

\begin{tabular}{l} 
FULL-TIME EQUIVALENTS (FTES) \\
\hline Organizational - Exempt \\
\hline Organizational - Nonexempt \\
\hline Organizational - Bargaining \\
\hline Total Organizational FTEs \\
\hline Support FTEs \\
\hline TOTALFTES
\end{tabular}

Cost Account Title

SMS Titlo

SWS - Industrial Security - Sitewide Administration

SWS - Industrial Security - Sitewide Administration

\section{COST ELEMENTS}

. Labor - Regular

. Labor - Overtime

o Total Labor

1 . Materials

2 Purchased Services

3 Other Hanford

4 Site Services

5 Internal Charges

6 IRM Suppon

7 Overheads

8 Revenue

TOTALDOLLARS

C.W. Walton

C.W. Walton

F.D. Lee

L.V. Jones

\begin{tabular}{|r|r|}
\hline \multicolumn{2}{|c|}{ FY1995 } \\
\hline Budget * & $\begin{array}{c}\text { Fiscal Year Spending } \\
\text { Forecast (FYSF) }\end{array}$ \\
\hline & \\
\hline & \\
\hline 0.0 & \\
\hline
\end{tabular}

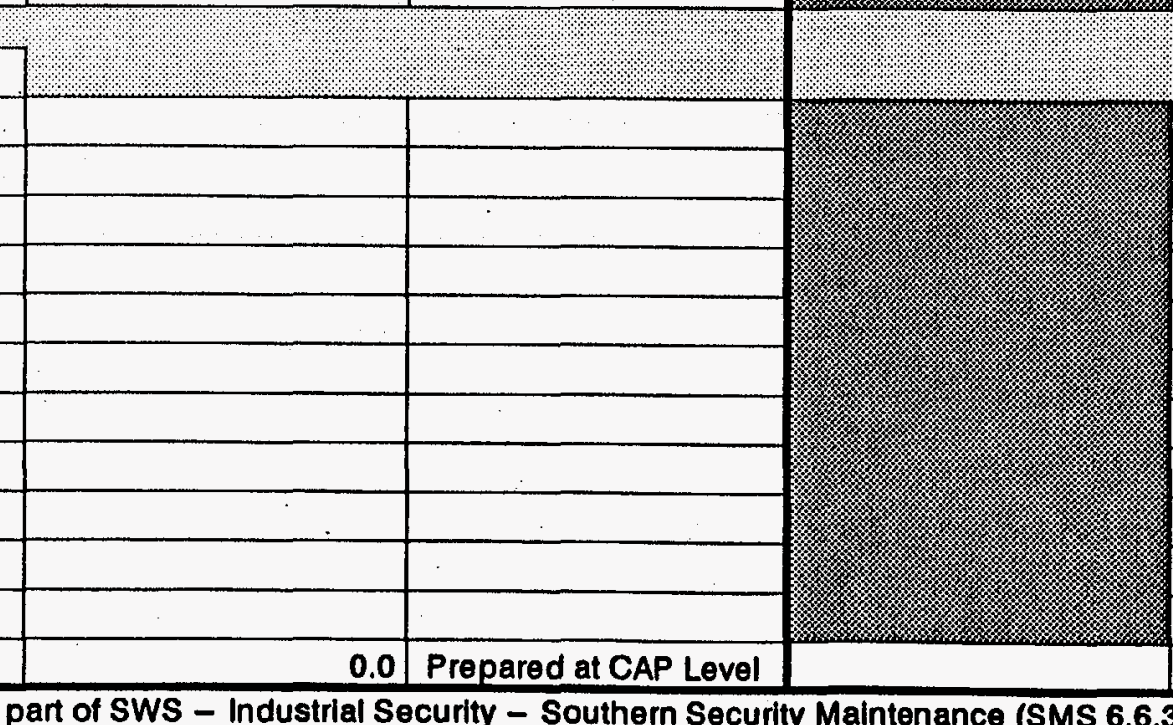

* FY 95 budget is previously shown as part of SWS - Industrial Security - Southern Securli dlscrete task.
Date

Date

Date

Date

Date

\section{Dato}

FY 1996 SSPP

Rev. \# 0

\begin{tabular}{|l|l|}
\hline G\&A \\
\hline SWS \\
\hline
\end{tabular}

SWS $\quad X X$

OST

DOH

MGT PRO

POOL

DIRECT

Annuallzed Rate

(For Organizational Overhead and Rated Service Pool Use Only) FY 1995 Rate $\quad$ FY 1996 Rate Request

-N/A-

FY 1996 Target Rate

$-N / A-$

FY 1996

\begin{tabular}{|c|c|c|}
\hline \multicolumn{2}{|c|}{ FY 1996 } & \multicolumn{1}{c|}{ Approved } \\
Baseline \\
Request
\end{tabular}

1.9
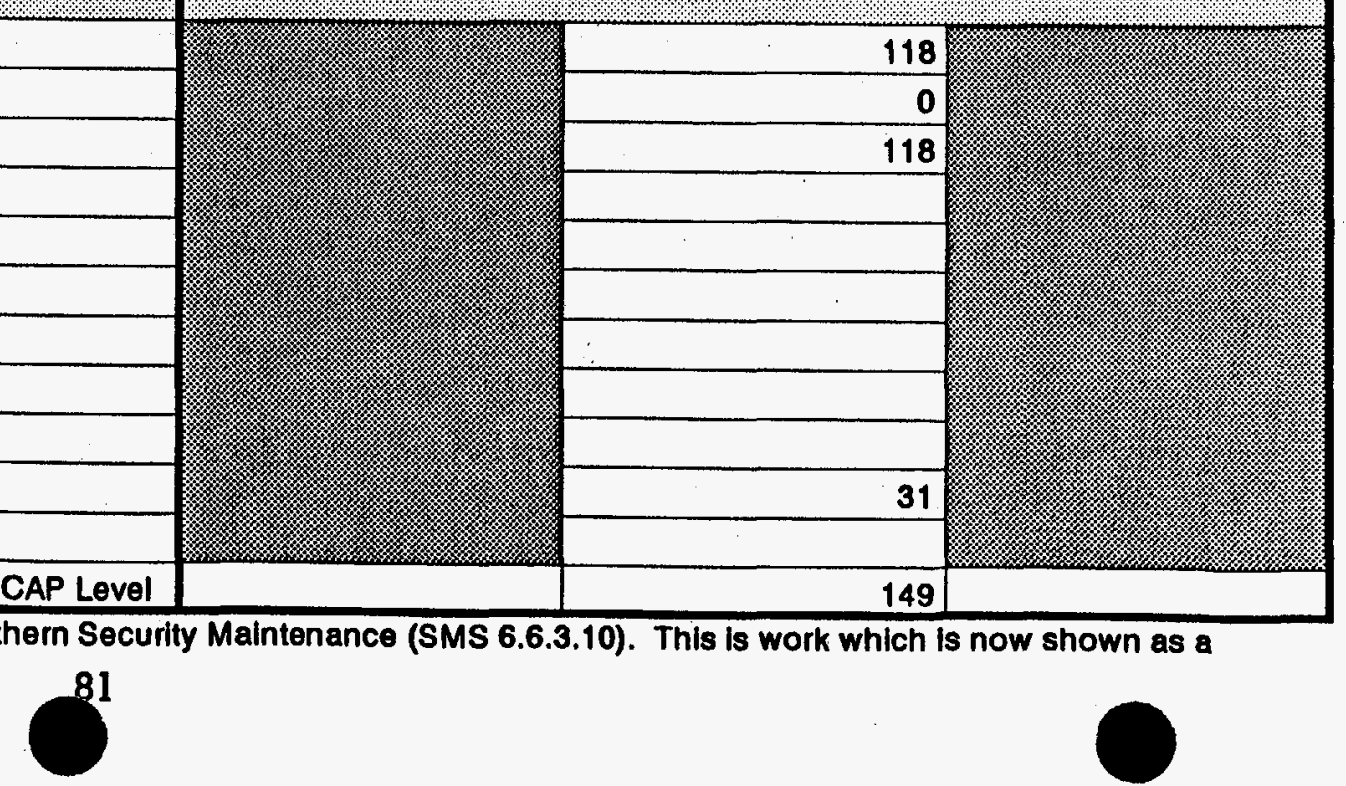


\begin{tabular}{|l|c|}
\hline Work Breakdown & Westinghouse Hanford Company \\
Structure & Safeguards and Security \\
Dictionary & Part II - Element Definition \\
\hline
\end{tabular}

\section{WBS ELEMENT CODE: 6.6.3.12}

\section{TASK DESCRIPTION (continued):}

Coordinate Site implementation of the RL Asset Protection Program for Property Protection and Limited Area facilities per RLID 5632.1B, "Asset Protection Requirements." This document established protection requirements for low-, medium-, and high-level assets assigned to WHC.

Provide daily guidance to employees on the application and implementation of WHC and DOE Order security requirements. Develop and implement a standardized lock and key program that ensures accountability for all security keys.

Elimination of this task would result in the following consequences:

Loss of a single point of contact to interface with RL SAS and other contractor security organizations resulting in inconsistent application of security requirements among contractors and a fragmented security program.

Loss of the security sensor testing program would result in a diminished detection capability of approximately 500 sensors, increasing the potential for loss of government property, classified matter or SNM, and increased maintenance costs.

Loss of a central point of contact in the Site selection task group would result in increased potential for violations of DOE Order requirements and creation of security vulnerabilities during construction of 1 and development activities.

Loss of coordination and oversight of the RL Asset Protection Program which would result in the ineffective implementation and execution of DOE Order requirements, loss control over high, medium and low assets assigned to WHC. 


\begin{tabular}{|l|c|c|}
\hline \multicolumn{1}{|c|}{ COST ACCOUNT } & \multicolumn{2}{|c|}{} \\
\hline $\begin{array}{l}\text { Work Breakdown } \\
\text { Structure } \\
\text { Dictionary }\end{array}$ & Westinghouse Hanford Company & Safeguards and Security \\
Part II - Element Definition & Fy & Revision \#0 \\
\hline
\end{tabular}

\begin{tabular}{|l|l|}
\hline WBS ELEMENT CODE: 6.6 .3 .12 & TITLE: Industrial Security Administration \\
\hline
\end{tabular}

\section{ELEMENT TASK DESCRIPTION}

\section{ASSUMPTIONS:}

- Access control procedures will be revised to reflect changing mission and/or order requirements.

- Property Protection Areas and Limited Areas will be maintained as required.

- The computer-based random search policy will be maintained to support the Patrol random search team.

- Staff support will be provided for a security evaluation review of the Hanford Site in FY 1996.

- DOE Order 5632.1C-1, "Protection and Control of Safeguards and Security Interests," and the RLID to 5632.1C will be fully implemented.

- There will be RL and HQ visits that will require staff support.

\section{MILESTONES:}

- 96-03 Complete and implement a computerized key control management program for building administrators/key custodians. $12 / 31 / 95$

- 96-04 Complete and implement a computerized management control program for the Omnilock ${ }^{\mathrm{TM}}$ access control systems. $12 / 31 / 95$ 
COST ACCOUNT

Work Breakdown

Structure

Dictionary
Westinghouse Hanford Company

Safeguards and Security

Part II - Element Definition
FY 1996 SSPP

Revision \#0

\begin{tabular}{|l|l}
\hline WBS ELEMENT CODE: 6 6.6.3.12 & TITLE: Industrial Security Administration \\
\hline
\end{tabular}

ELEMENT TASK DESCRIPTION

DELIVERABLES:

- Maintain the multicontractor Hanford security interest maps to document locations of security interests and Limited Areas. Submit to RL every six months (January and July).

- DOE Order and RLID reviews.

- WHC Controlled Manual Reviews.

- Upgrade signs at Site Limited Areas to reflect current requirements for security clearance symbols and use of sign in/out logs. 


\begin{tabular}{|c|c|c|}
\hline $\begin{array}{l}\text { Sitewide Support (SWS) Patrol } \\
\text { Summary }\end{array}$ & $\begin{array}{c}\text { Westinghouse Hanford Company } \\
\text { Safeguards and Security } \\
\text { WBS } 6.6\end{array}$ & $\begin{array}{c}\text { FY } 1996 \\
\text { Program Plan } \\
\text { August 31, } 1995\end{array}$ \\
\hline
\end{tabular}

\section{Total FY 1996}

\begin{tabular}{||l||c|c|c||}
\hline SMS & \multicolumn{1}{|c|}{ Sitewide Support Patrol WBS/SMS 6.6.4 } & FTE & \$ In 000's \\
\hline \hline 6.6 .4 & Sitewide Support (SWS) Patrol & 97.4 & 7,762 \\
\hline \hline & Elimination of Cross Charging & & $(1,626)$ \\
\hline & TOTAL: & & 6,136 \\
\hline
\end{tabular}




\begin{tabular}{|c|c|c|c|c|c|c|c|c|c|}
\hline $\begin{array}{l}\text { Work } \\
\text { Breakdown } \\
\text { Structure } \\
\text { Dictionary }\end{array}$ & \multicolumn{6}{|c|}{$\begin{array}{c}\text { Westinghouse Hanford Company } \\
\text { Safeguards and Security } \\
\text { Part I - Summary } \\
\text { (Dollars in 000's) }\end{array}$} & \multicolumn{3}{|c|}{$\begin{array}{l}\text { FY } 1996 \\
\text { Indirect } \\
\text { Program Plan } \\
\text { Rev. \# } 0\end{array}$} \\
\hline $\begin{array}{r}\text { Cost Account Number } \\
1 \mathrm{MDB} 0 \mathrm{A0} 0101\end{array}$ & \multicolumn{6}{|c|}{ Cost Account Title } & \multicolumn{3}{|c|}{$\begin{array}{l}\text { Proposed Rate: } \\
\text { (Rated Service Pool Only) }\end{array}$} \\
\hline $\begin{array}{r}\text { SMS WBS Number } \\
6.6 .4 \\
\end{array}$ & \multicolumn{6}{|l|}{ SMS Title } & \multicolumn{3}{|c|}{ Funding Source: } \\
\hline RL SMS Program Manger & \multicolumn{6}{|l|}{ J.L. Spracklen } & \multicolumn{3}{|l|}{ sws } \\
\hline Cost Account Manager & \multicolumn{6}{|l|}{ C.W. Walton } & \multicolumn{3}{|l|}{ OST } \\
\hline WHC SMS Program Manager & \multicolumn{6}{|l|}{ C.W. Walton } & \multicolumn{3}{|l|}{ DOH } \\
\hline Financial Manager & \multicolumn{6}{|l|}{ F.D. Lee } & \multicolumn{3}{|l|}{ MGT PRO } \\
\hline Responsible Analyst & \multicolumn{6}{|l|}{ L.V. Jones } & \multicolumn{3}{|l|}{ POOL } \\
\hline & \multicolumn{3}{|c|}{$\begin{array}{l}\text { FY } 1996 \text { Approved Funding } \\
\text { Full-Time Equivalents (FTEs) }\end{array}$} & \multicolumn{3}{|c|}{$\begin{array}{l}\text { FY } 1996 \text { Unfunded } \\
\text { Full-Time Equivalents (FTEs) }\end{array}$} & \multicolumn{3}{|c|}{$\begin{array}{c}\text { FY } 1996 \text { Baseline } \\
\text { Full-Time Equivalents (FTEs) }\end{array}$} \\
\hline TYPE OF FTE & Exempt & Non-Exempt & Bargaining & Exempt & Non-Exempt & Bargaining & Exempt & Non-Exempt & Bargaining \\
\hline Organizational & 28.2 & 1.8 & 67.4 & & & & 28.2 & 1.8 & 67.4 \\
\hline Support & & & & & & & 0.0 & 0.0 & 0.0 \\
\hline TOTALFTES & 28.2 & 1.8 & 67.4 & 0.0 & 0.0 & 0.0 & 28.2 & 1.8 & 67.4 \\
\hline COST ELEMENTS & \multicolumn{3}{|c|}{ FY 1996 Approved Funding Budget } & \multicolumn{3}{|c|}{ FY 1996 Unfunded Budget } & \multicolumn{3}{|c|}{ FY 1996 Baseline Budget } \\
\hline . Labor - Regular & & & 5,214 & & & & & & 5,214 \\
\hline . Labor - Overtime & & & 922 & & & & & & 922 \\
\hline 0 Total Labor & & & 6,136 & & & 0 & & & 6,136 \\
\hline 1 Materials & & & & & & & & & 0 \\
\hline 2 Purchased Services & & & & & & & & & 0 \\
\hline 3 Other Hanford & & & & & & & & & 0 \\
\hline Subtotal Originated Costs & & & 6,136 & & & 0. & & & 6,136 \\
\hline 4 Site Services & & & & & & & & & 0 \\
\hline 5 Internal Charges & & & & & & & & & 0 \\
\hline 6 IRM Support & & & & & & & & & 0 \\
\hline 7 Overheads & & & 1,626 & & & & & & 1,626 \\
\hline 8 Revenue & & & & & & & & & 0 \\
\hline TOTAL DOLLARS & & & 7,762 & & & 0 & & & 7,762 \\
\hline $\begin{array}{l}\text { SIGNATURES } \\
\text { Financial Analyst: } \\
\text { CAM: }\end{array}$ & & 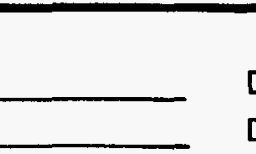 & $\begin{array}{l}\text { Date: } \\
\text { Date: }\end{array}$ & & BASELINE API & PROVAL & & & Date: \\
\hline
\end{tabular}




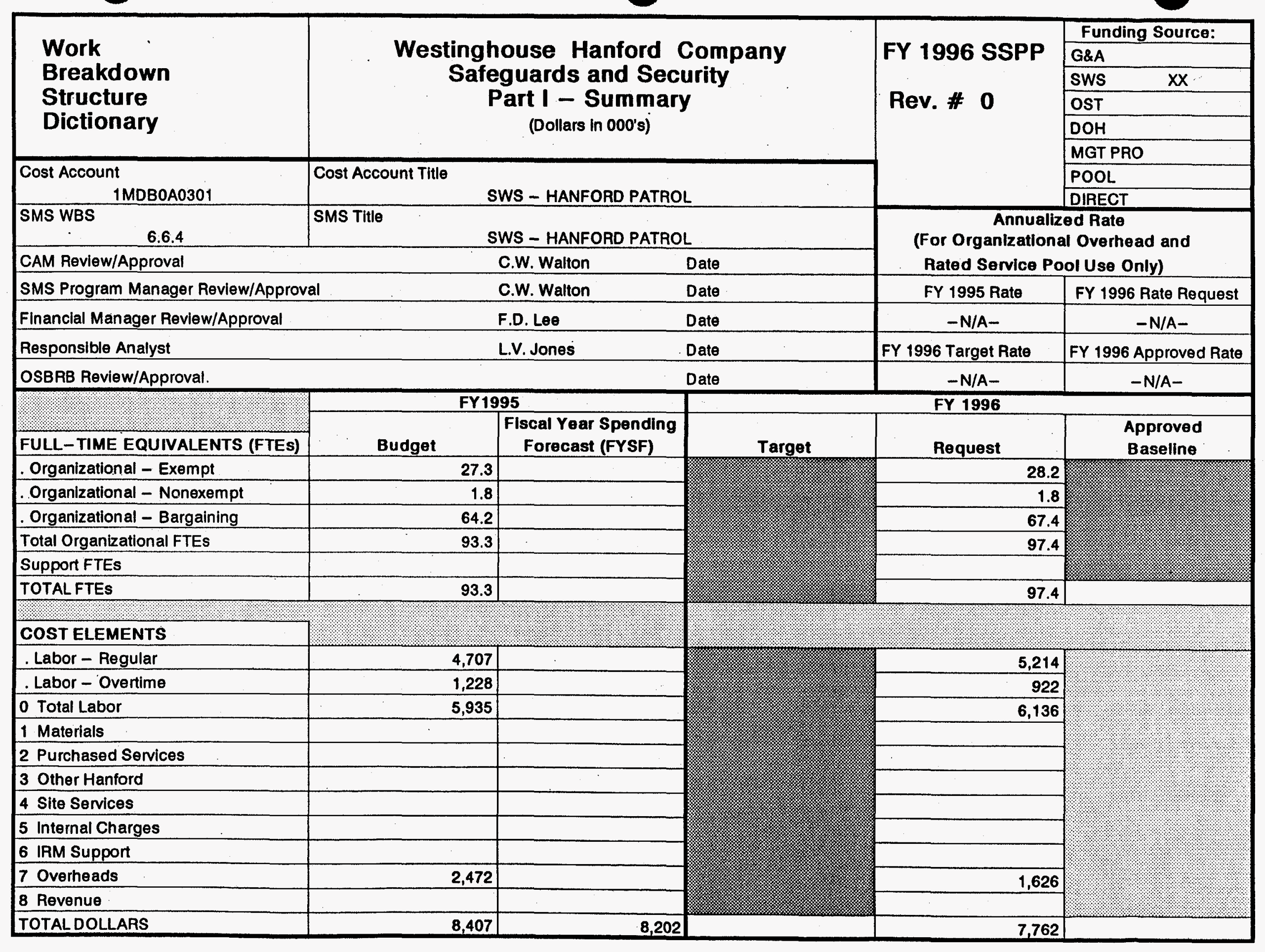


COST ACCOUNT

\begin{tabular}{|l|c|}
\hline Work Breakdown & Westinghouse Hanford Company \\
Structure & Safeguards and Security \\
Dictionary & Part II - Element Definition \\
\hline
\end{tabular}

WBS ELEMENT CODE: $\mathbf{6 . 6 . 4}$

TITLE: Hanford Patrol Support to Sitewide Support

\section{ELEMENT TASK DESCRIPTION}

FUNDING SOURCE: Sitewide Support (SWS)

\section{TASK DESCRIPTION:}

Provide a professional protective force that is highly trained and effective in techniques for physical protection, emergency response, and public service. The Hanford Site is supported on a 24-hour basis by the Special Response Team (SRT), the Site Barricades, Patrol Administration/Management, Patrol Operations Center (POC), Patrol Training Academy (PTA), and portions of the Northern/Southern Area Patrol Operations.

- The SRT provides a special weapons and tactical response to critical emergencies throughout the Site.

Elimination of the SRT will result in escalated risk of successful theft or sabotage of nuclear materials at Hanford facilities. The Site would have no adequate, dedicated response to acts of sabotage directed at numerous toxicological targets. Full explanation of the risk of SRT elimination is classified. Requirements are described in the Site Safeguards and Security Plan, Vulnerability Analyses for the Fast Flux Test Facility (FFTF), PFP, K-Basins and Patrol Contingency PIans. Requirement for the SRT capability is predescribed by U.S. Department of Energy (DOE) Orders. DOE Orders require Special Nuclear Materials (SNM) Category II or greater to be stored in Protected Areas. At Hanford, neither the FFTF nor the K-Basins meet this requirement. Waivers of this requirement have been granted, which have saved millions of dollars. The SRT response was critical to these waivers, and they would most certainly be rescinded if the SRT was eliminated. 
COST ACCOUNT

\begin{tabular}{|l|c|c|}
\hline $\begin{array}{l}\text { Work Breakdown } \\
\text { Structure } \\
\text { Dictionary }\end{array}$ & $\begin{array}{c}\text { Westinghouse Hanford Company } \\
\text { Safeguards and Security } \\
\text { Part II - Element Definition }\end{array}$ & FY 1996 SSPP \\
Revision \#0 \\
\hline
\end{tabular}

\begin{tabular}{|l|l}
\hline WBS ELEMENT CODE: 6.6 .4 & TITLE: Hanford Patrol Support to Sitewide Support \\
\hline
\end{tabular}

\section{ELEMENT TASK DESCRIPTION}

\section{TASK DESCRIPTION (continued):}

- Provide access control to the northern portions of the Site 24-hours per day at the WYE and Yakima Barricades and 10-hours-per-day at the Rattlesnake Barricade.

If eliminated there would be no ability to provide timely protective actions to cordon off the northern part of the Site during emergencies and to control access to northern part of the Site. If the barricades are removed, Department of Transportation and Hazardous Material Transportation requirements would apply. This would result in millions of dollars in incremental costs. Sightseeing, vandalism, and theft would not be deterred or detected due to lack of access control and infrequent roving patrois in the northern part of the Site. Since the hazardous waste permit baseline includes access control, with removal of Patrol, other compensatory measures (i.e., fences, gatelocks) must be implemented.

- Patrol Management/Administration provides protective force with procedure development/publication, participation in required performance testing, vulnerability and analyses, safety awareness, monitoring/tracking of audit deficiencies, and support of improvement programs. Operationally it administers special search and operations programs, bargaining unit management, provides leadership, command, and control during emergencies.

An armed protective force requires active management for safety and conduct of operations. Hanford has the leanest protective force of any major site. DOE Orders require "adequate" levels of administration, supervision, and management. Current levels are barely so, today's posture is minimal. Patrol would be unable to maintain or comply with required Hanford emergency plans. 
COST ACCOUNT

\begin{tabular}{|l|c|}
\hline $\begin{array}{l}\text { Work Breakdown } \\
\text { Structure }\end{array}$ & Westinghouse Hanford Company \\
Dictionary & Safeguards and Security \\
Part II - Element Definition
\end{tabular}

FY 1996 SSPP

Part II - Element Definition

Revision \#0

WBS ELEMENT CODE: 6.6 .4

TITLE: Hanford Patrol Support to Sitewide Support

\section{ELEMENT TASK DESCRIPTION}

\section{TASK DESCRIPTION (continued):}

- The POC provides 24-hour emergency dispatch capability to Hanford Patrol, Benton County Sheriff's 0ffice, and initial incident notification to the Hanford Fire Department.

Without a POC, there will be no 911 emergency dispatch service for Hanford. Onsite and offsite centralized emergency notifications would be severely jeopardized. These include; law enforcement/fire dispatch, emergency evacuation action and notifications, classified "Open Skies" and shipment information, and access authorization during offshift hours. Another facility will have to be designated for industrial alarm annunciation as well as redundant SNM alarms. Emergency Preparedness would have to make alternative arrangement for emergency notifications/communications.

- The PTA provides required initial and recurrent training/qualification to protective force officers including firearms, defensive tactics, field tactics, security procedures, report writing and documentation, physical fitness, and safety radiation/blood born pathogens protection.

Elimination of the PTA would cause WHC and RL to be in violation of 10 CFR 1046, "Physical Protection of Security Interests," which mandates specific levels of training, qualification, and medical/fitness for DOE and contractor protective forces pertaining to training and certification of officers. It would be a violation of law, contractual obligations between WHC and DOE, as well as the Hanford Guard's Union. Storage and processing of nuclear and hazardous materials at Hanford would be indefensible were a trained, certified and legally compliant protective force not maintained at the Site. 
COST ACCOUNT

\begin{tabular}{|l|c|c|}
\hline $\begin{array}{l}\text { Work Breakdown } \\
\text { Structure } \\
\text { Dictionary }\end{array}$ & Westinghouse Hanford Company & Fr 1996 SSPP \\
\end{tabular}

\begin{tabular}{|l|l|}
\hline WBS ELEMENT CODE: 6.6 .4 & TITLE: Hanford Patrol Support to Sitewide Support \\
\hline ELEMENT TASK DESCRIPTION \\
IASK DESCRIPTION (continued):
\end{tabular}

- Northern/Southern Area Patrol Operations provide required and immediate armed response to attempted theft or sabotage of SNM as well as toxicologically hazardous storage locations and, provide assistance of a general nature to Site and other personnel in accordance with DOE Order 5480.16, "Firearms Safety, " DOE Order 5632.7, "Protective Forces," DOE Order 5631.1A, "Protection Program Operation," DOE Order 5632.1C, "Protection and Control of Safeguards and Security Interests," and "SSSP/VA/Contingency Plans."

If eliminated WHC will be unable to adequately protect SNM and hazardous materials in its care. High risk of serious injury or death to onsite and offsite personnel in the case of malevolent acts at several northern area facilities will result from el imination of northern area rovers. Issuance of temporary badges, alarm and emergency call response, etc., will either cease or be greatly delayed. Risk will be elevated at K-Basins, Solid Waste Disposal, Tank Farms, B Plant \& other northern area facilities.

\section{ASSUMPTIONS:}

- The Patrol force will continue to be responsible for response and control of any incident that threatens 1 ife or property on the Site until relieved by other authority. The Occurrence Notification Center and Fire Dispatch will be consolidated into the POC in fiscal year 1996. Funding for the incremental work to be transferred is in the Emergency Preparedness' and Hanford Fire's SSPP and not in the Safeguards and Security's SSPP. 


\begin{tabular}{|l|c|c|}
\hline \multicolumn{1}{|c|}{ COST ACcouNT } & \multicolumn{2}{|c|}{ FY 1996 SSPP } \\
\hline $\begin{array}{l}\text { Work Breakdown } \\
\text { Structure } \\
\text { Dictionary }\end{array}$ & Westinghouse Hanford Company & Safeguards and Security \\
\hline
\end{tabular}

WBS ELEMENT CODE: 6.6 .4

TITLE: Hanford Patrol Support to Sitewide Support

\section{ELEMENT TASK DESCRIPTION}

MILESTONES:

- 96-05 Complete Emergency Medical Dispatcher Training for all Patrol Operations Center personnel. 01/31/96

- 96-06 Implement Simunitions ${ }^{\text {TM }}$ Training Program for Security Police 0fficer (SP0) IIIs 02/01/96

- 96-10 Implement a Canine Explosive Detector Program 06/01/96

- 96-15 All Special Response Team Lieutenants complete Central Training Academy's Firearm Instructor Certification $09 / 30 / 96$

- 96-16 Complete 48 Limited Scope Performance Test exercises 09/30/96

DELIVERABLES:

- Professionally-trained protective force that provides Sitewide response, emergency communications, access control and the necessary management tools to ensure continuity of site security. 


\begin{tabular}{|c|c|c|}
\hline Traffic Safety Summary & $\begin{array}{c}\text { Westinghouse Hanford Company } \\
\text { Safeguards and Security } \\
\text { WBS } 6.6\end{array}$ & $\begin{array}{c}\text { FY } 1996 \\
\text { Program Plan } \\
\text { August } 31,1995\end{array}$ \\
\hline
\end{tabular}

\section{Total FY 1996}

\begin{tabular}{|c||c|c|c||}
\hline SMS & \multicolumn{1}{|c|}{ Traffic Safety WBS/SMS 6.6.5 } & FTE & \$In O00's \\
\hline 6.6 .5 & Traffic Safety & 2.0 & 198 \\
\hline \hline & Elimination of cross charging & & $(39)$ \\
\hline \hline & TOTAL: & & 158 \\
\hline
\end{tabular}




\begin{tabular}{|c|c|c|c|c|c|c|c|c|c|}
\hline $\begin{array}{l}\text { Work } \\
\text { Breakdown } \\
\text { Structure } \\
\text { Dictionary }\end{array}$ & \multicolumn{6}{|c|}{$\begin{array}{c}\text { Westinghouse Hanford Company } \\
\text { Safeguards and Security } \\
\text { Part I - Summary } \\
\text { (Dollars in 000's) }\end{array}$} & \multicolumn{3}{|c|}{$\begin{array}{l}\text { FY } 1996 \\
\text { Indirect } \\
\text { Program Plan } \\
\text { Rev. \# } 0\end{array}$} \\
\hline $\begin{array}{c}\text { Cost Account Number } \\
\text { 1MDDVS }\end{array}$ & \multicolumn{6}{|c|}{ Cost Account Title } & \multicolumn{3}{|c|}{$\begin{array}{l}\text { Proposed Rate: } \\
\text { (Rated Service Pool Only) }\end{array}$} \\
\hline $\begin{array}{r}\text { SMS WBS Number } \\
6.6 .5 \\
\end{array}$ & \multicolumn{6}{|c|}{ Hanford Vehicle Safety Program } & G\&A & Funding Source: & \\
\hline RL SMS Program Manger & \multicolumn{6}{|l|}{ J. L. Spracklen } & \multicolumn{3}{|l|}{ sws } \\
\hline Cost Account Manager & \multicolumn{6}{|l|}{ 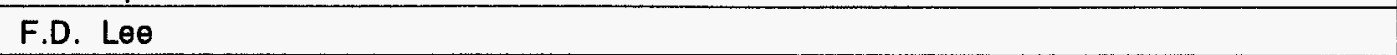 } & \multicolumn{3}{|l|}{ OST } \\
\hline WHC SMS Program Manager & \multicolumn{6}{|l|}{ C.W. Walton } & \multicolumn{3}{|l|}{$\mathrm{DOH}$} \\
\hline Financial Manager & \multicolumn{6}{|l|}{ F.D. Lee } & \multicolumn{3}{|l|}{ MGT PRO } \\
\hline Responsible Analyst & \multicolumn{6}{|c|}{ E.T. Thompson } & \multicolumn{3}{|l|}{ POOL } \\
\hline & \multicolumn{3}{|c|}{$\begin{array}{l}\text { FY } 1996 \text { Approved Funding } \\
\text { Full-Time Equivalents (FTEs) }\end{array}$} & \multicolumn{3}{|c|}{$\begin{array}{l}\text { FY } 1996 \text { Unfunded } \\
\text { Full-Time Equivalents (FTEs) }\end{array}$} & \multicolumn{3}{|c|}{$\begin{array}{c}\text { FY } 1996 \text { Baseline } \\
\text { Full-Time Equivalents (FTEs) }\end{array}$} \\
\hline TYPE OF FTE & Exempt & Non-Exempt & Bargaining & Exempt & Non-Exempt & Bargaining & Exempt & Non-Exempt & Bargaining \\
\hline Organizational & 2.0 & & & & & & 2.0 & 0.0 & 0.0 \\
\hline Support & & & & & & & 0.0 & 0.0 & 0.0 \\
\hline TOTALFTES & 2.0 & 0.0 & 0.0 & 0.0 & 0.0 & 0.0 & 2.0 & 0.0 & 0.0 \\
\hline COST ELEMENTS & \multicolumn{3}{|c|}{ FY 1996 Approved Funding Budget } & \multicolumn{3}{|c|}{ FY 1996 Unfunded Budget } & \multicolumn{3}{|c|}{ FY 1996 Baseline Budget } \\
\hline Labor - Regular & & & 146 & & & & & & 146 \\
\hline . Labor - Overtime & & & & & & & & & 0 \\
\hline 0 Total Labor & & & 146 & & & 0 & & & 146 \\
\hline 1 Materials & & & 2 & & & & & & 2 \\
\hline 2 Purchased Services & & & 7 & & & & & & 7 \\
\hline 3 Other Hanford & & & 1 & & & & & & 1 \\
\hline Subtotal Originated Costs & & & 156 & & & 0 & & & 156 \\
\hline 4 Site Services & & & 2 & & & & & & 2 \\
\hline 5 Internal Charges & & & & & & & & & 0 \\
\hline 6 IRM Support & & & 2 & & & & & & 2 \\
\hline 7 Overheads & & & 39 & & & & & & 39 \\
\hline 8 Revenue & & & & & & & & & 0 \\
\hline TOTAL DOLLARS & & & 198 & & & 0 & & & 198 \\
\hline
\end{tabular}

\begin{tabular}{|ll|}
\hline SIGNATURES & Date: \\
Financial Analyst: & Date: \\
CAM: & \\
\hline
\end{tabular}

BASELINE APPROVAL 


\begin{tabular}{|c|c|c|c|c|c|}
\hline \multirow{6}{*}{$\begin{array}{l}\text { Work } \\
\text { Breakdown } \\
\text { Structure } \\
\text { Dictionary }\end{array}$} & \multirow{6}{*}{\multicolumn{3}{|c|}{$\begin{array}{c}\text { Westinghouse Hanford Company } \\
\text { Safeguards and Security } \\
\text { Part I - Summary } \\
\text { (Dollars in } 000^{\prime} \text { 's) }\end{array}$}} & \multirow{8}{*}{$\begin{array}{l}\text { FY } 1996 \text { SSPP } \\
\text { Rev. \# } 0\end{array}$} & Funding Source: \\
\hline & & & & & \begin{tabular}{|ll}
$G \& A$ & $X X$ \\
\end{tabular} \\
\hline & & & & & SWS \\
\hline & & & & & OST \\
\hline & & & & & \multirow{2}{*}{\begin{tabular}{|l|} 
DOH \\
MGT PRO
\end{tabular}} \\
\hline & & & & & \\
\hline Cost Account & Cost Account Title & & & & \\
\hline 1MDDVS & \multicolumn{3}{|c|}{ Traffic Safety } & & \begin{tabular}{|l} 
POOL \\
DIRECT \\
\end{tabular} \\
\hline $\begin{array}{ll}\text { SMS WBS } & 6.6 .5 \\
\end{array}$ & \multicolumn{3}{|c|}{ Hanford Vehicle Safety Program } & \multirow{2}{*}{\multicolumn{2}{|c|}{$\begin{array}{c}\text { Annualized Rate } \\
\text { (For Organizational Overhead and } \\
\text { Rated Service Pool Use Only) } \\
\end{array}$}} \\
\hline CAM Review/Approval: & \multicolumn{3}{|c|}{$\begin{array}{l}\text { Date } \\
\end{array}$} & & \\
\hline SMS Program Manager Review/Approval & al: C.W. Walton & & Date & FY 1995 Rate & FY 1996 Rate Request \\
\hline Financial Manager Review/Approval: & F.D. Lee & & Date & $-N / A-$ & $-N / A-$ \\
\hline Responsible Analyst: & E.T. Thompson & & Date & FY 1996 Target Rate & FY 1996 Approved Rate \\
\hline OSBRB Review/Approval & & & Date & $-N / A-$ & $-N / A-$ \\
\hline & FY19: & 995 & & FY 1996 & \\
\hline FULL_-TIME EQUIVALENTS (FTES) & Budget & \begin{tabular}{|c|}
$\begin{array}{c}\text { Fiscal Year Spending } \\
\text { Forecast (FYSF) }\end{array}$ \\
\end{tabular} & Target & Request & $\begin{array}{l}\text { Approved } \\
\text { Baseline }\end{array}$ \\
\hline Organizational - Exempt & 4.0 & & & 2.0 & \\
\hline . Organizational - Nonexempt & 1.0 & & & & \\
\hline . Organizational - Bargaining & & & & & \\
\hline Total Organizational FTEs & 5.0 & & & 2.0 & \\
\hline Support FTEs & & & & & \\
\hline TOTALFTES & 5.0 & & & 2.0 & \\
\hline Labor - Regular & 295 & & & 146 & \\
\hline . Labor - Overtime & 0 & & & 0 & \\
\hline 0 Total Labor & 295 & & & 146 & \\
\hline 1 Materials & 10 & & & 2 & \\
\hline 2 Purchased Services & 13 & & & 7 & \\
\hline 3 Other Hanford & 0 & & & 1 & \\
\hline 4 Site Services & 2 & & & 2 & \\
\hline 5 Internal Charges & 0 & & & 0 & \\
\hline 6 IRM Support & 6 & & & 2 & \\
\hline 7 Overheads & 121 & & & 39 & \\
\hline 8 Revenue & 0 & & & 0 & \\
\hline TOTALDOLLARS & 446 & 333 & & 198 & \\
\hline
\end{tabular}




\begin{tabular}{l|c} 
Work Breakdown & Westinghouse Hanford Company \\
Structure & Safeguards and Security \\
Dictionary & Part II - Element Definition
\end{tabular}

\begin{tabular}{|l|l|}
\hline WBS ELEMENT CODE: 6.6 .5 & TITLE: Traffic Safety \\
\hline
\end{tabular}

\section{ELEMENT TASK DESCRIPTION}

FUNDING SOURCE: General and Administrative (G\&A)

\section{TASK DESCRIPTION:}

Traffic Safety supports accident reduction and compliance requirements defined by U.S. Department of Energy (DOE) Order 3791.2A, "Motor Vehicle Safety Program, " DOE-RLIP 3791.2, "Motor Vehicles, " 49 CFR Chapter III, "Federal Highway Administration, Department of Transportation, and Title 46, Revised Code for Washington, "Motor Vehicles."

Traffic Safety is a comprehensive sitewide motor vehicle/pedestrian safety program. The program assigns responsibility and accountability for all Westinghouse Hanford Company and subcontractor motor vehicle/pedestrian activities. It encompasses the use and operation of government vehicles and the use of roadways and pedestrian walkways on the Hanford Site.

The Site road systems currently maintain a level of service that exceeds or pushes the threshold of safe operations. The operations areas are congested and were not designed to safely handle the level of pedestrian/vehicle traffic required by the mission. Constant monitoring of traffic flows, accident trends, and modification of traffic control devices allows our road systems and operations areas to safely support the level of service the Site mission demands.

With the privatization of the Site, constant coordination is required between the Site Traffic Engineer and the surrounding cities, counties, port authorities, transit groups, and State Traffic Engineering groups to ensure smooth and safe operations of our transportation systems and transition of responsibilities as lands and roadways are returned to the local authorities.

The concerns of individual employee and Accident Prevention Councils concerning roadways, parking lots, and walkways are fielded by Traffic Safety. The concerns are addressed and staffed to ensure immediate abatement of hazards and provide a safe work environment. 


\begin{tabular}{|l|c|c|}
\hline \multicolumn{2}{|c|}{ COST ACCOUNT } & \multicolumn{2}{|c|}{} \\
\hline $\begin{array}{l}\text { Work Breakdown } \\
\text { Structure } \\
\text { Dictionary }\end{array}$ & Westinghouse Hanford Company & Safeguards and Security \\
Part II - Element Definition & FY 1996 SSPP \\
\hline
\end{tabular}

WBS ELEMENT CODE: 6.6 .5

TITLE: Traffic Safety

ELEMENT TASK DESCRIPTION

TASK DESCRIPTION (continued):

The elimination of this task would greatly increase the risk potential for the following:

The potential for a fatality accident is high without constant monitoring and preventive actions.

Civil liabilities related to improper placement and maintenance of required traffic control devices and roadways.

Unresolved or improperly handled employee concerns.

Worksite hazards are ignored or unsatisfactorily resolved.

Support and coordination between the Site and other government agencies.

Design reviews.

Occupational Safety and Health Administration Voluntary Protection Program Star Status.

\section{ASSUMPTIONS:}

None identified. 


\begin{tabular}{|l|c|c|}
\hline \multicolumn{1}{|c|}{ COST ACCOUNT } & \multicolumn{2}{|l|}{} \\
\hline $\begin{array}{l}\text { Work Breakdown } \\
\text { Structure } \\
\text { Dictionary }\end{array}$ & $\begin{array}{c}\text { Westinghouse Hanford Company } \\
\text { Safeguards and Security } \\
\text { Part II - Element Definition }\end{array}$ & FY 1996 SSPP \\
\hline
\end{tabular}

\begin{tabular}{|l|l|}
\hline WBS ELEMENT CODE: 6.6 .5 & TITLE: Traffic Safety \\
\hline ELEMENT TASK DESCRIPTION \\
MILESTONES: \\
None ident ified \\
DELIVERABLES: \\
- Safety procedures and training programs to meet the intent of DOE Orders, federal, state and local laws. \\
\end{tabular}




\begin{tabular}{|l|c|c|}
\hline Locksmiths Summary & $\begin{array}{c}\text { Westinghouse Hanford Company } \\
\text { Safeguards and Security } \\
\text { WBS 6.6 }\end{array}$ & $\begin{array}{c}\text { FY 1996 } \\
\text { Program Plan } \\
\text { August 31, 1995 }\end{array}$ \\
\hline
\end{tabular}

\section{Total FY 1996}

\begin{tabular}{|c||l|c|c||}
\hline SMS & \multicolumn{1}{|c|}{ Locksmiths WBS/SMS 6.6.6 } & FTE & \$In 000's \\
\hline \hline 6.6 .6 & Locksmiths Direct Charging Service Center & 7.4 & 737 \\
\hline \hline & Elimination of cross charging & & $(110)$ \\
\hline \hline & TOTAL: & & 627 \\
\hline
\end{tabular}




\begin{tabular}{|c|c|c|c|c|c|c|c|c|c|}
\hline $\begin{array}{l}\text { Work } \\
\text { Breakdown } \\
\text { Structure } \\
\text { Dictionary }\end{array}$ & \multicolumn{6}{|c|}{$\begin{array}{c}\text { Westinghouse Hanford Company } \\
\text { Safeguards and Security } \\
\text { Part I - Summary } \\
\text { (Dollars in 000's) }\end{array}$} & \multicolumn{3}{|c|}{$\begin{array}{l}\text { FY } 1996 \\
\text { Indirect } \\
\text { Program Plan } \\
\text { Rev. \# } 0\end{array}$} \\
\hline $\begin{array}{r}\text { Cost Account Number } \\
1 \mathrm{MDCOC}\end{array}$ & \multicolumn{6}{|c|}{ Cost Account Title } & \multicolumn{3}{|c|}{$\begin{array}{l}\text { Proposed Rate: } \$ 66.41 / \mathrm{hr} \\
\text { (Rated Service Pool Oniy) }\end{array}$} \\
\hline $\begin{array}{r}\text { SMS WBS Number } \\
6.6 .6\end{array}$ & \multicolumn{6}{|c|}{ LOCKSMITH SI } & \multicolumn{3}{|c|}{ Funding Source: } \\
\hline RL SMS Program Manger & \multicolumn{6}{|l|}{ J. L. Spracklen } & \multicolumn{3}{|l|}{ SWS } \\
\hline Cost Account Manager & \multicolumn{6}{|l|}{ D.J. Haskins } & \multicolumn{3}{|l|}{ OST } \\
\hline WHC SMS Program Manager & \multicolumn{6}{|l|}{ C.W. Walton } & \multicolumn{3}{|l|}{$\mathrm{DOH}$} \\
\hline Financial Manager & \multicolumn{6}{|l|}{ F.D. Le } & \multicolumn{3}{|l|}{ MGT PRO } \\
\hline Responsible Analyst & \multicolumn{6}{|c|}{ E.T. Thompson } & \multirow{2}{*}{\multicolumn{3}{|c|}{$\begin{array}{|lc|}\text { POOL } & \text { XX } \\
& \text { FY } 1996 \text { Baseline } \\
\text { Full-Time Equivalents (FTEs) }\end{array}$}} \\
\hline & \multicolumn{3}{|c|}{$\begin{array}{c}\text { FY } 1996 \text { Approved Funding } \\
\text { Full-Time Equivalents (FTEs) }\end{array}$} & \multicolumn{3}{|c|}{$\begin{array}{l}\text { FY } 1996 \text { Unfunded } \\
\text { Full-Time Equivalents (FTEs) }\end{array}$} & & & \\
\hline TYPE OF FTE & Exempt & Non-Exempt & Bargaining & Exempt & Non-Exempt & Bargaining & Exempt & Non-Exempt & \begin{tabular}{|l|} 
Bargaining \\
\end{tabular} \\
\hline Organizational & 1.5 & & 4.5 & & & & 1.5 & 0.0 & 4.5 \\
\hline Support & 0.2 & 1.0 & 0.2 & & & & 0.2 & 1.0 & 0.2 \\
\hline TOTALFTES & 1.7 & 1.0 & 4.7 & 0.0 & 0.0 & 0.0 & 1.7 & 1.0 & 4.7 \\
\hline COST ELEMENTS & \multicolumn{3}{|c|}{ FY 1996 Approved Funding Budget } & \multicolumn{3}{|c|}{ FY 1996 Unfunded Budget } & \multicolumn{3}{|c|}{ FY 1996 Baseline Budget } \\
\hline Labor - Regular & & & 397.7 & & & & & & 397.7 \\
\hline Labor - Overtime & & & & & & & & & 0.0 \\
\hline 0 Total Labor & & & 397.7 & & & 0.0 & & & 397.7 \\
\hline 1 Materials & & & 200.0 & & & & & & 200.0 \\
\hline 2 Purchased Services & & & & & & & & & 0.0 \\
\hline 3 Other Hanford & & & & & & & & & 0.0 \\
\hline Subtotal originated costs & & & 5977 & & & 0.0 & & & 5977 \\
\hline 4 Site Services & & & 29.8 & & & & & & 29.8 \\
\hline 5 Internal Charges & & & & & & & & & 0.0 \\
\hline 6 IRM Support & & & & & & & & & 0.0 \\
\hline 7 Overheads & & & 109.9 & & & & & & 109.9 \\
\hline 8 Revenue & & & & & & & & & 0.0 \\
\hline TOTAL DOLLARS & 18 & & 737.5 & & & 0.0 & & & 737.5 \\
\hline $\begin{array}{l}\text { SIGNATURES } \\
\text { Financial Analyst: } \\
\text { CAM: } \\
\end{array}$ & & 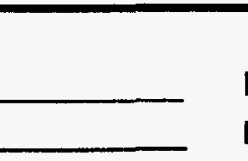 & $\begin{array}{l}\text { Date: } \\
\text { Date: }\end{array}$ & & BASELINE API & PROVAL & & & Date: \\
\hline
\end{tabular}




\begin{tabular}{|c|c|c|c|c|c|}
\hline \multirow{6}{*}{$\begin{array}{l}\text { Work } \\
\text { Breakdown } \\
\text { Structure } \\
\text { Dictionary }\end{array}$} & \multirow{5}{*}{\multicolumn{3}{|c|}{$\begin{array}{c}\text { Westinghouse Hanford Company } \\
\text { Safeguards and Security } \\
\text { Part I - Summary } \\
\text { (Dollars in 000's) }\end{array}$}} & \multirow{8}{*}{$\begin{array}{l}\text { FY } 1996 \text { SSPP } \\
\text { Rev. \# } 0\end{array}$} & Funding Source: \\
\hline & & & & & G\&A \\
\hline & & & & & sws \\
\hline & & & & & OST \\
\hline & & & & & $\mathrm{DOH}$ \\
\hline & & & & & MGT PRO \\
\hline Cost Account & Cost Account Title & & & & POOL \\
\hline $1 \mathrm{MDCOC}$ & \multicolumn{3}{|c|}{ Locksmiths (Summary) } & & DIRECT \\
\hline $\begin{array}{ll}\text { SMS WBS } & 6.6 .6 \\
\end{array}$ & \multicolumn{3}{|c|}{ Hanford Locksmith Services } & \multirow{2}{*}{\multicolumn{2}{|c|}{$\begin{array}{c}\text { Annualized Rate } \\
\text { (For Organizational Overhead and } \\
\text { Rated Service Pool Use Only) }\end{array}$}} \\
\hline CAM Review/Approval: & D.J. Haskins & & Date & & \\
\hline \multicolumn{2}{|c|}{ SMS Program Manager Review/Approval: C.W. Walton } & \multicolumn{2}{|r|}{ Date } & FY 1995 Rate / hr & FY 1996 Rate Request \\
\hline Financial Manager Review/Approval: & F.D. Lee & & Date & 85.76 & 66.41 \\
\hline Responsible Analyst: & E.T. Thompson & & Date & FY 1996 Target Rate / hr & FY 1996 Approved Rate \\
\hline OSBRB Review/Approval & & & Date & 85.76 & \\
\hline & \multicolumn{2}{|c|}{ FY1995 } & \multirow[b]{2}{*}{ Target } & FY 1996 & \multirow[b]{2}{*}{$\begin{array}{l}\text { Approved } \\
\text { Basellne }\end{array}$} \\
\hline FULL-TIME EQUIVALENTS (FTES) & Budget & \begin{tabular}{|c|}
$\begin{array}{c}\text { Fiscal Year Spending } \\
\text { Forecast (FYSF) }\end{array}$ \\
\end{tabular} & & & \\
\hline . Organizational - Exempt & 1.3 & & & \multirow[t]{2}{*}{1.5} & \multirow{2}{*}{ 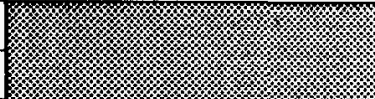 } \\
\hline . Organizational - Nonexempt & 0.5 & & & & \\
\hline . Organizational - Bargaining & 5.0 & & & 4.5 & \\
\hline Total Organizational FTEs & 6.8 & & & \multirow{2}{*}{6.0} & \\
\hline Support FTEs & 0.4 & & & & \\
\hline TOTAL FTES & 7.2 & & & 7.4 & \\
\hline $\begin{array}{l}\text { (1. } \\
\text { COST ELEMENTS }\end{array}$ & & & & & \\
\hline . Labor - Regular & 414 & & & 398 & \\
\hline . Labor - Overtime & 10 & & & 0 & \\
\hline 0 Total Labor & 423 & & & 398 & \\
\hline 1 Materials & 204 & & & 200 & \\
\hline 2 Purchased Services & 1 & & & & \\
\hline 3 Other Hanford & . & & & & \\
\hline 4 Site Services & 44 & & & 30 & \\
\hline 5 internal Charges & & & & & \\
\hline 6 IRM Support & 3 & & & & \\
\hline 7 Overheads & 177 & & & 110 & \\
\hline 8 Revenue & & & & & \\
\hline TOTAL DOLLARS & 852 & 766 & & 737 & \\
\hline
\end{tabular}


COST ÁCCOUNT

\begin{tabular}{l|c} 
Work Breakdown & Westinghouse Hanford Company \\
Structure & Safeguards and Security \\
Dictionary & Part II - Element Definition
\end{tabular}

WBS ELEMENT CODE: $\mathbf{6 . 6 . 6}$

TITLE: Locksmiths, SNM, Classified and Industrial Security

\section{ELEMENT TASK DESCRIPTION}

FUNDING SOURCE: Direct Charging Service Center

\section{TASK DESCRIPTION:}

Provide multicontractor locksmith services to install, replace, and maintain locks, keys, and access control systems for the protection of nuclear materials (including Special Nuclear Material [SNM]) and classified materials, and to protect against radiological and toxicological sabotage issues in facilities/buildings located throughout the Hanford Site.

Provide multicontractor locksmith services to install, replace, and maintain locks, keys, and access control systems in over 1100 government leased and owned facilities/buildings throughout the Hanford Site.

Elimination of this task will result in the following consequences:

Increased risk of theft or compromise of classified matter, up to Secret Restricted Data, due to inability to maintain/install locking hardware.

Loss of access to SNM or classified documents in the event of a vault lock malfunction while in the closed position. Increased risk of theft or diversion of nuclear materials due to inability to maintain/install locking hardware to process and storage locations.

Increased risk of radiological and toxicological sabotage resulting from inability to install or repair locking hardware. 


\begin{tabular}{|l|c|c|}
\hline \multicolumn{2}{|c|}{ COST ACCOUNT } & \multicolumn{2}{|c|}{} \\
\hline $\begin{array}{l}\text { Work Breakdown } \\
\text { Structure } \\
\text { Dictionary }\end{array}$ & Westinghouse Hanford Company & Safeguards and Security \\
Part II - Element Definition & FY 1996 SSPP \\
\hline
\end{tabular}

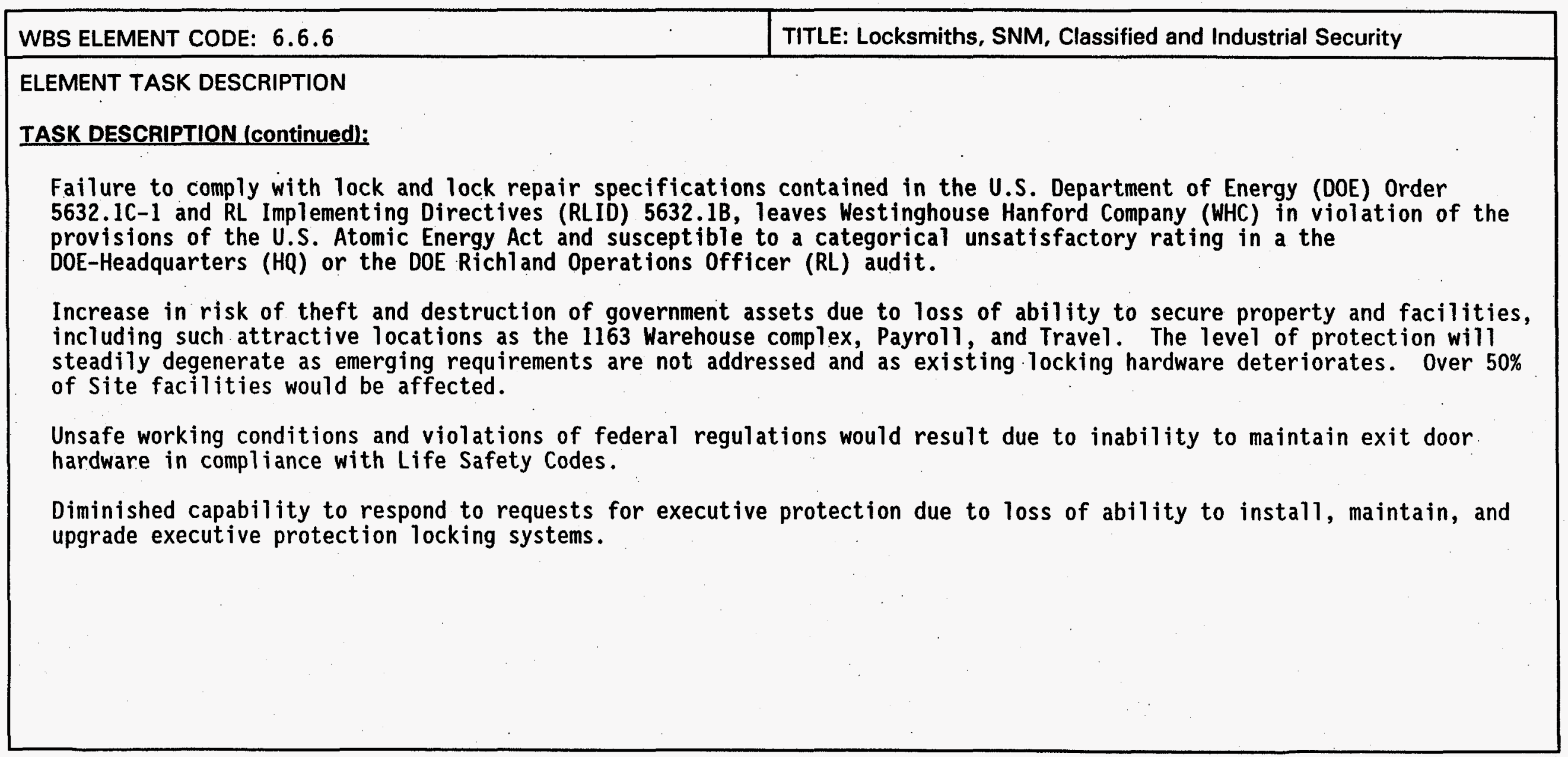


COST ACCOUNT

\begin{tabular}{|l|c|c|}
\hline Work Breakdown & Westinghouse Hanford Company \\
Structure & Safeguards and Security \\
Dictionary & Part II - Element Definition & FY 1996 SSPP \\
\hline
\end{tabular}

\begin{tabular}{|l|l}
\hline WBS ELEMENT CODE: 6.6 .6 & TITLE: Locksmiths, SNM, Classified and Industrial Security \\
\hline
\end{tabular}

ELEMENT TASK DESCRIPTION

ASSUMPTIONS:

None identified.

MILESTONES:

None identified.

DELIVERABLES:

- Locksmiths Services Program - Maintain in fiscal year 1996 to support compliance with the DOE Order 5632.1C-1 and RLID 5632.1B to install and maintain locks, keys, and access control systems as requested by the RL, WHC, ICF Kaiser Hanford Company, Bechtel Hanford, Inc., and Pacific Northwest Laboratory.

- Safely maintain a fully compliant hazardous waste satellite retention center. 


\section{SAFEGUARDS AND SECURITY \\ Total Staffing Priorities - FY 1996 By Task}

\begin{tabular}{|c|c|c|c|c|}
\hline \multicolumn{5}{|l|}{ BUILDING BLOCKS FOR FY 1996} \\
\hline \multicolumn{5}{|l|}{ FY 1996 Building Blocke $(\$ 000)$} \\
\hline ORGANIZATIONAL WORK SCOPE DESCRIPTION & $\begin{array}{c}\text { ORG. FTE } \\
\text { IN } \\
\text { WORKSCOPE. }\end{array}$ & $\begin{array}{c}\text { SUPPORT } \\
\text { FTE\& IN } \\
\text { WORKSCOPE }\end{array}$ & $\begin{array}{c}\text { FY } 1996 \\
\text { ORIQINAL } \\
\text { COST } \\
\end{array}$ & JUSTIFICATION OF SCOPE/MPACT IF NOT FUNDED \\
\hline 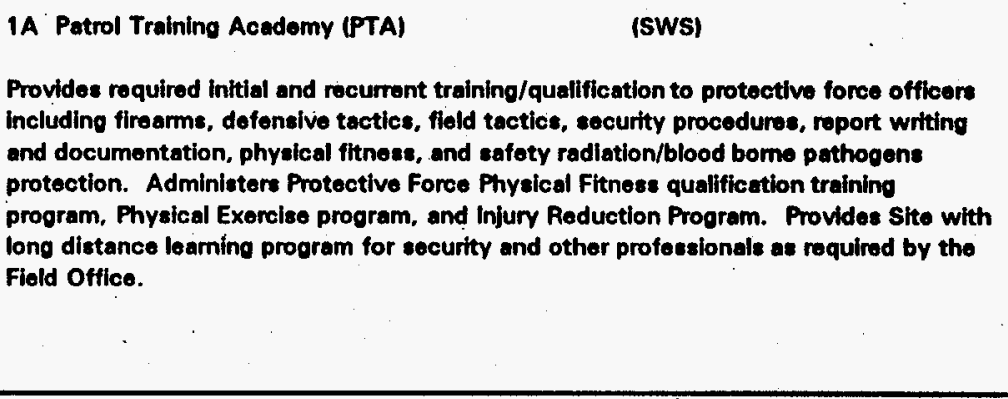 & $\begin{array}{c}6.3 \text { (EX) } \\
.4 \text { (NE) }\end{array}$ & & $496.0 \mathrm{~K}$ & 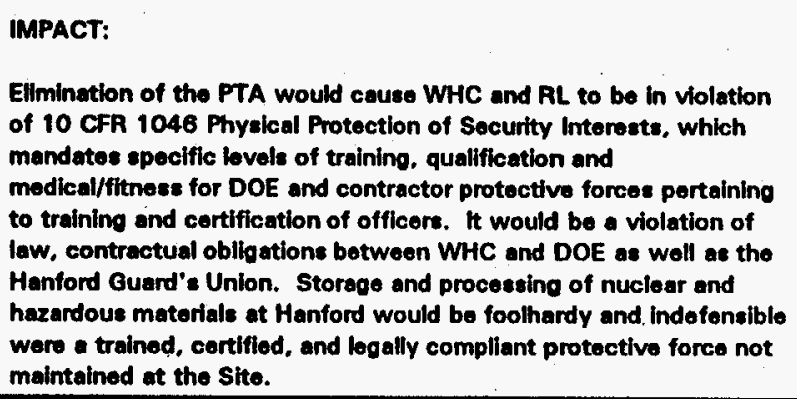 \\
\hline $\begin{array}{l}\text { 1B Special Response Toam (SPH } \\
\text { (SWS) } \\
\text { Provide Special Woapons and Tactics (SWAT) response to critical omorgenolos } \\
\text { throughout the Site including attempted theft of category I or II nuclear materials } \\
\text { lincluding weapons grade), radiological or toxicological sabotage, and volent crimes } \\
\text { such as assaults, hostage situations which require specialized personnel and } \\
\text { equipment to carry out high risk operations. }\end{array}$ & $\begin{array}{c}6.0(\mathrm{EX}) \\
28.0(\mathrm{BU})\end{array}$ & . & $2,000.0 \mathrm{~K}$ & 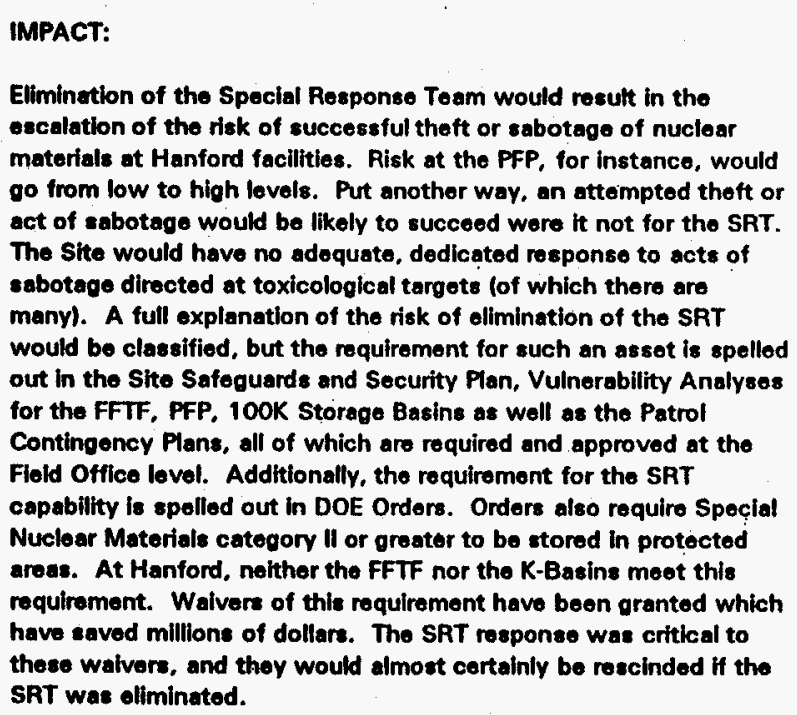 \\
\hline
\end{tabular}


SAFEGUARDS AND SECURITY

Total Staffing Priorities - FY 1996 By Task

Page 2

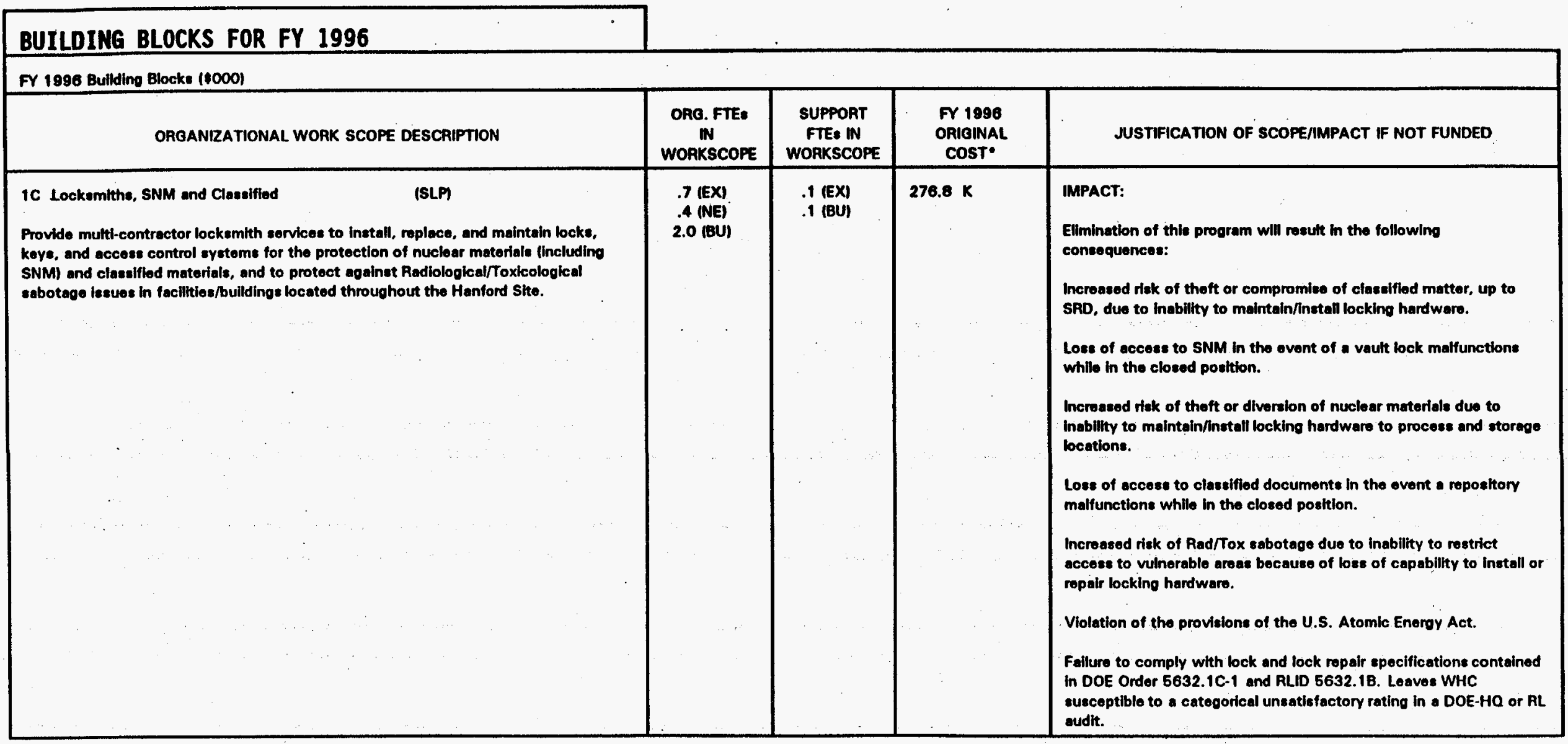




$$
-1
$$


SAFEGUARDS AND SECURITY

Total Staffing Priorities - FY 1996 By Task

\section{BUILDING BLOCKS FOR FY 1996}

FY 1996 Building Blocks (1900)

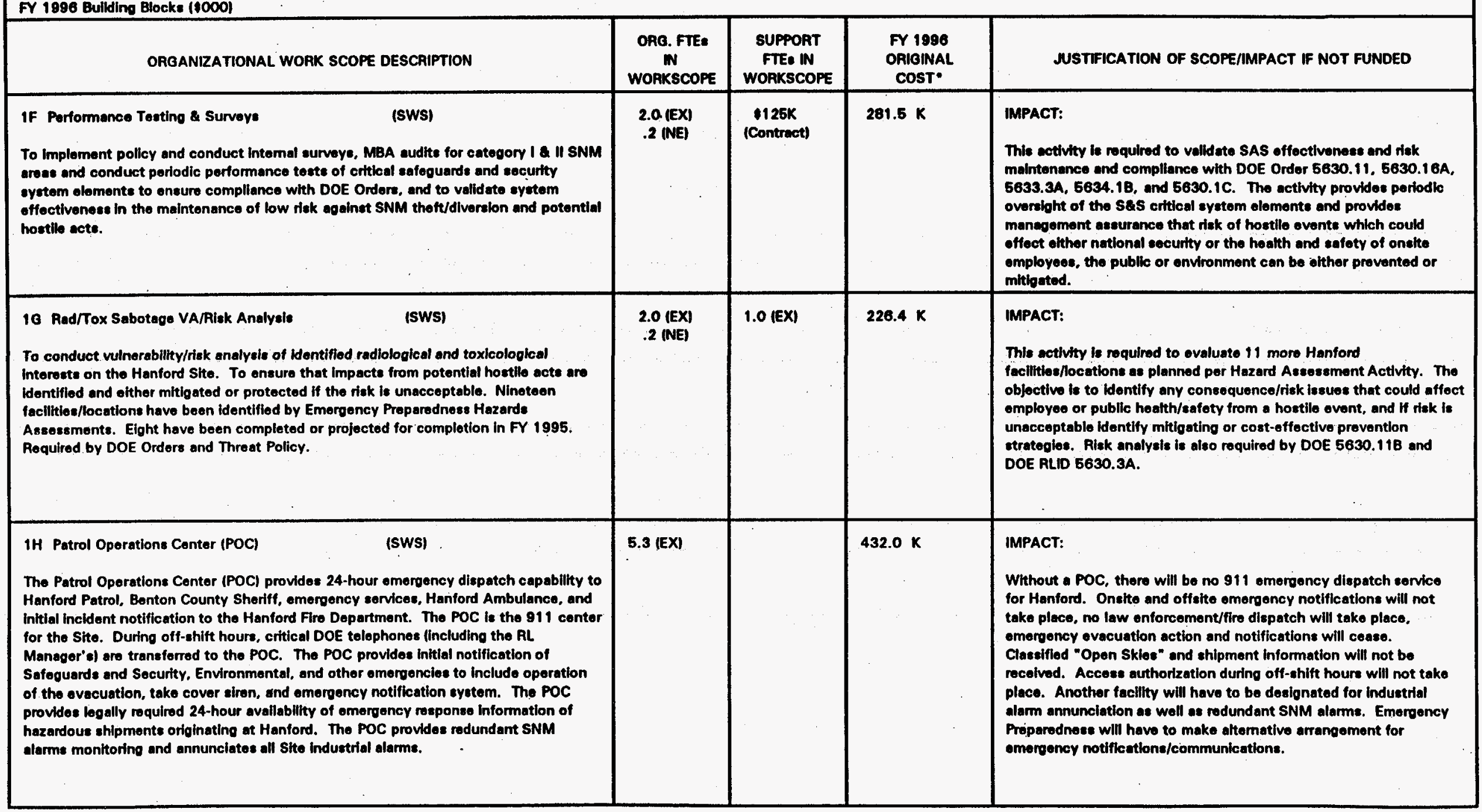




\section{SAFEGUARDS AND SECURITY \\ Total Staffing Priorities - FY 1996 By Task}

\begin{tabular}{|c|c|c|c|c|}
\hline \multicolumn{5}{|l|}{ BUILDING BLOCKS FOR FY 1996} \\
\hline \multicolumn{5}{|l|}{ FY 1996 Building Blocks (\$000) } \\
\hline ORGANIZATIONAL WORK SCOPE DESCRIPTION & $\begin{array}{l}\text { OAO. FTE } \\
\text { WN } \\
\text { WORKSCOPE }\end{array}$ & $\begin{array}{l}\text { SUPPORT } \\
\text { FTES IN } \\
\text { WORKSCOPE }\end{array}$ & $\begin{array}{l}\text { FY } 1996 \\
\text { ORIGINAL } \\
\text { COST* }\end{array}$ & JUSTIFICATION OF SCOPE/IMPACT IF NOT FUNDED \\
\hline $\begin{array}{l}\text { (I) Throat Evaluations } \\
\text { To provide tochnical support in rovieing and doveloping riak analysis mothodology. } \\
\text { Dovolop a mothod that provides a capability for a management mitigation factor that } \\
\text { would be appliod to adjust base case risk. }\end{array}$ & $\begin{array}{l}.6 \text { (EX) } \\
.1 \text { (NE) } \\
.\end{array}$ & & $40.4 K$ & $\begin{array}{l}\text { IMPACT: } \\
\text { Analyais of the DOE threat polley as it affects the ability of WHC to } \\
\text { protect against rad/tox sabotege and theft of SNM would not take } \\
\text { place. This could allow an unaccoptablo condition to dovelop. }\end{array}$ \\
\hline $\begin{array}{l}\text { 2A Badging Operation } \\
\text { Manufacture, iseue and account for permanent socurtty ldentification badoes for all } \\
\text { Sito contractors, viattors, vendors and DOE personnol as required by DOE order. } \\
\text { Implement and control the Site tomporary security badging program in compliance } \\
\text { with DOE badging policy. } \\
\text { Conduct fingerprinting in support of security cloarance processing activitios as } \\
\text { required by OOE Order. } \\
\text { Manage security badging operations for ICF KH at the } 1301 \text { facility. Includes } \\
\text { coordination and issuance of HEHF medical scheduling with subcontractor personnol } \\
\text { and presentation of Site informational safety and security videos and brochures. }\end{array}$ & $\begin{array}{l}1.0 \text { (EX) } \\
6.0 \text { (NE) }\end{array}$ & $\begin{array}{l}1.0 \text { (EX) } \\
.3 \text { (BU) }\end{array}$ & $475.1 K$ & 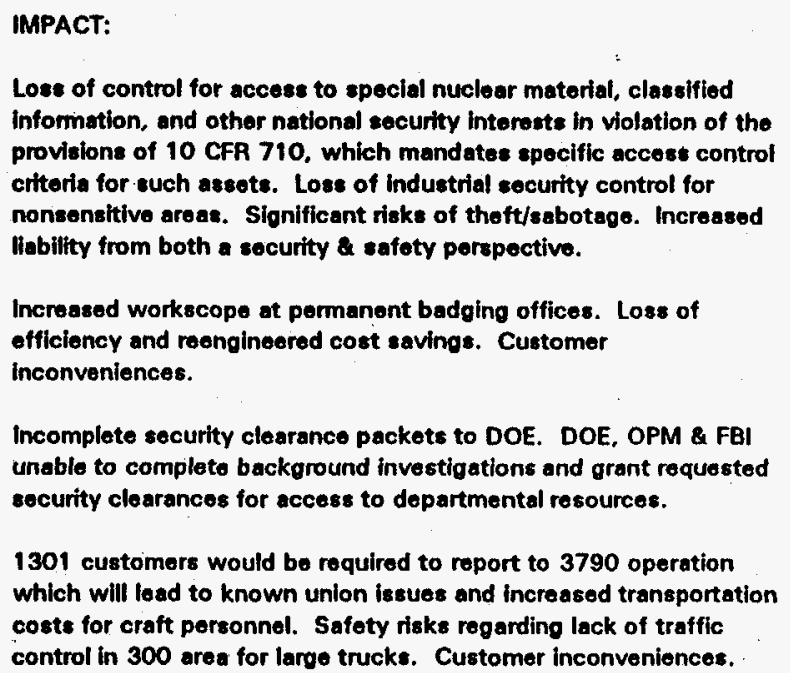 \\
\hline
\end{tabular}




\section{SAFEGUARDS AND SECURITY}

Total Staffing Priorities - FY 1996 By Task

\begin{tabular}{|c|c|c|c|c|}
\hline \multicolumn{5}{|l|}{ BUILDING BLOCKS FOR FY 1996} \\
\hline \multicolumn{5}{|l|}{ Fr. 1996 Bullding Block: $(1000)$} \\
\hline OROANIZATIONAL WORK SCOPE DESCRIPTION & $\begin{array}{c}\text { ORO. FTE } \\
\text { WN } \\
\text { WORKSCOPE }\end{array}$ & $\begin{array}{c}\text { SUPPORT } \\
\text { FTEs IN } \\
\text { WORKSCOPE }\end{array}$ & $\begin{array}{l}\text { FY } 1996 \\
\text { ORIGINAL } \\
\text { COST. }\end{array}$ & JUSTIFICATION OF SCOPE/MMPACT IF NOT FUNDED \\
\hline 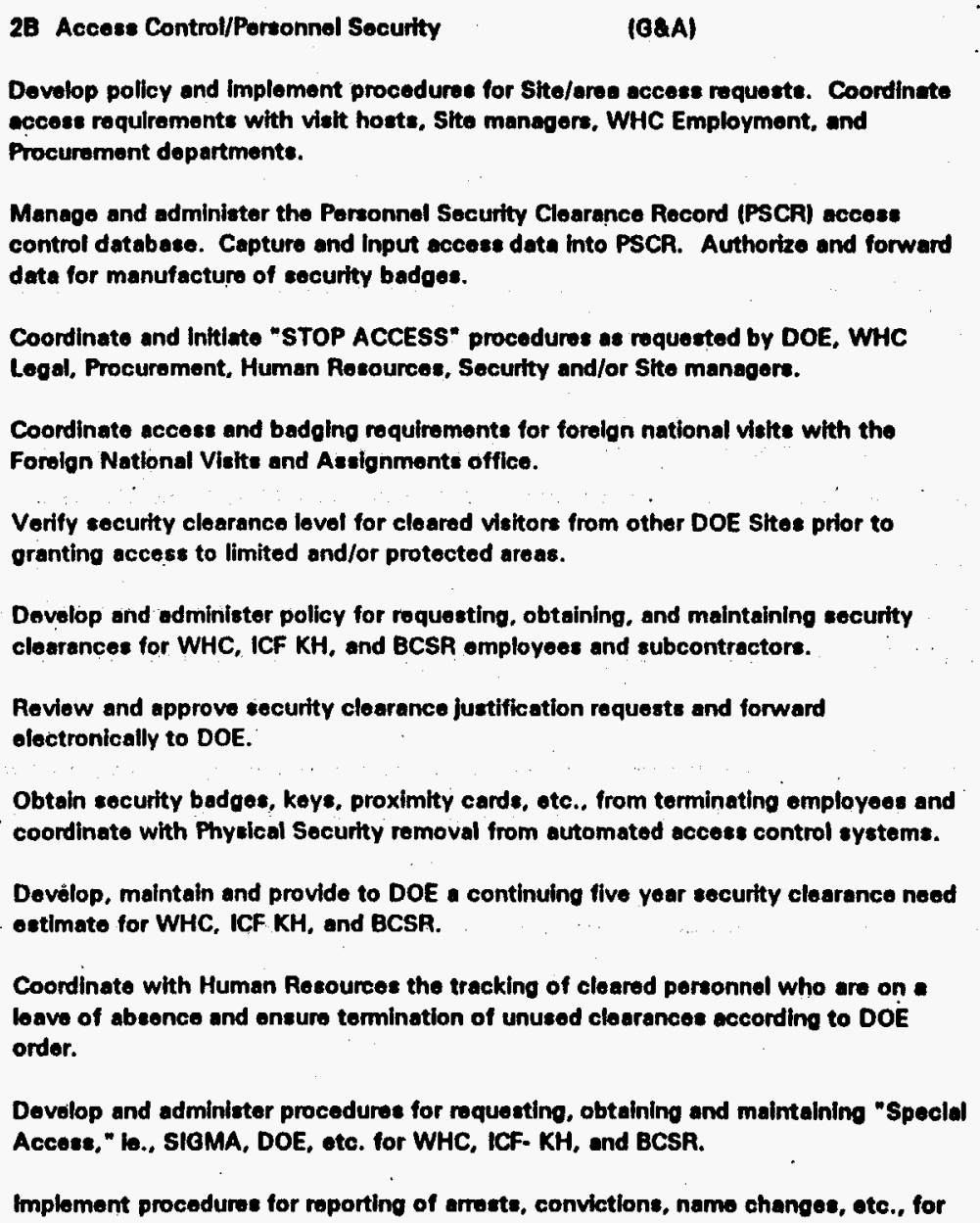 & $\begin{array}{l}5.0 \text { (EX) } \\
6.0 \text { (NE) } \\
.3(\mathrm{BU})\end{array}$ & .8 (EX) & $704.9 \mathrm{~K}$ & 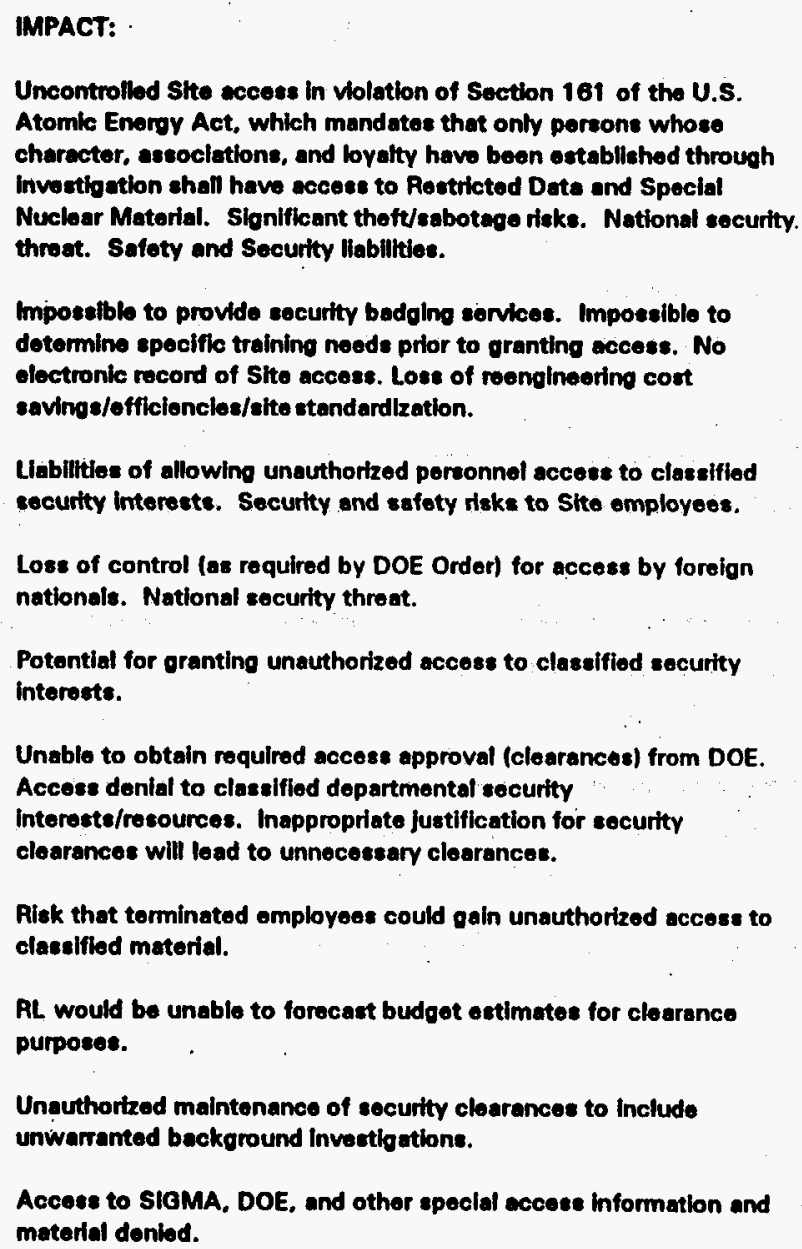 \\
\hline
\end{tabular}


SAFEGUARDS AND SECURITY

Total Staffing Priorities - FY 1996 By Task

\begin{tabular}{|c|c|c|c|c|}
\hline \multicolumn{5}{|l|}{ BUILDING BLOCKS FOR FY 1996} \\
\hline \multicolumn{5}{|l|}{ FY 1996 Building Blocks $(\$ 000)$} \\
\hline ORGANIZATIONAL WORK SCOPE DESCRIPTION & $\begin{array}{l}\text { ORG. FTEs } \\
\text { IN } \\
\text { WORKSCOPE }\end{array}$ & $\begin{array}{l}\text { SUPPORT } \\
\text { FTEs IN } \\
\text { WORKSCOPE }\end{array}$ & $\begin{array}{l}\text { FY } 1996 \\
\text { ORIGINAL } \\
\text { COST }\end{array}$ & JUSTIFICATION OF SCOPE/IMPACT IF NOT FUNDED \\
\hline $\begin{array}{l}\text { 2C Classification } \\
\text { IG\&A) } \\
\text { implement and sustain a program that identifies classified information to ensure its } \\
\text { protection. }\end{array}$ & $\begin{array}{c}2.1 \text { (EX) } \\
.2 \text { (NE) }\end{array}$ & . & $163.0 \mathrm{~K}$ & $\begin{array}{l}\text { IMPACT: } \\
\text { Loss of control of classified information in violation of the provisions } \\
\text { of Section } 141 \text { and } 142 \text { of the U.S. Atomic Energy Act and } \\
\text { Executive Order } 12958 \text { which establish requirements for control of } \\
\text { information. Loss of Unclassified, Controlled Nuclear Information } \\
\text { (UCNI) through negligence could subject WHC and its officers to } \\
\text { severe criminal penalties under Titlo } 18 \text { USC Section } 793 \text {. Fines } \\
\text { and assessments for failure to implement adequate measures to } \\
\text { identify and protect classified information. }\end{array}$ \\
\hline $\begin{array}{l}\text { 2D Classified Computer Security }(G \& A) \\
\text { Ensure the security of classified information processed and stored on computers. }\end{array}$ & $\begin{array}{l}1.2 \text { (EX) } \\
.2 \text { (NE) }\end{array}$ & & $99.2 \mathrm{~K}$ & $\begin{array}{l}\text { IMPACT: } \\
\text { Loss of control of classified national security information. Fines and } \\
\text { assessments for failing to property implement the Executivo Order } \\
\text { on National Security Information and OMB Circular A-130. }\end{array}$ \\
\hline
\end{tabular}




\section{SAFEGUARDS AND SECURITY}

Total Staffing Priorities - FY 1996 By Task

\section{BUILDING BLOCKS FOR FY 1996}

FY 1996 Building Blocks $(\$ 000)$

ORGANIZATIONAL WORK SCOPE DESCRIPTION

\begin{tabular}{c|c|c}
\hline $\begin{array}{c}\text { ORG. FTEs } \\
\text { IN }\end{array}$ & $\begin{array}{c}\text { SUPPORT } \\
\text { FTEs IN } \\
\text { WORKSCOPE }\end{array}$ & $\begin{array}{c}\text { FY } 1996 \\
\text { ORIGINAL } \\
\text { WORKSCOPE }\end{array}$ \\
\hline
\end{tabular}

WORKSCOPE WORKSCOPE

\begin{tabular}{l|l|l}
\hline 1.4 (EX) & $117.7 \mathrm{~K}$
\end{tabular}

2E Industrial Security Administration

(sWs)

Coordinate implementation of security initiatives in the areas of Physical Security Security Systems Testing, and Project Coordination as demonstrated through the following:

Development of the Random Search/Security Badge Inspection program, Host-Visitor requirements, prohibited articles policy, and program documentation in the WHC

Security Manual (WHC-CM-4-33)

Serve as a single point of contact for RL SAS for Task Team development and review of DOE Orders and coordination of RL and HO SAS tours.

Function as load in multi-contractor activities to ensure standardized application of DOE order requirements, to include activitios such as the recent accelerated DOE

Order Reduction Program which consolidated 27 orders to 11.

Serve as Security Operations point of contact in corrective action planning and administration for facility specific issues identified during DOE and internal surveys.

Administer and coordinate a security system sensor testing program to ensure standardized testing of approximately 500 sensors in accordance with DOE security system sensor testing criteria.

Provide SAS representation on the WHC Site Selection Task Group to assure security requirements are met for all Site land development, disturbances or improvements.

Coordinate Site implementation of the RL Asset Protection Program for Property Protection and Limited Area facilities per RLID 5632.1B, "Asset Protection Requirements." This document established protection requirements for lowmedium-, and

high-level assets assigned to WHC.

Provide daily guidance to employees on the application and implementation of WHC and DOE Order security requirements.

\section{.5 (NE)}

$117.7 \mathrm{~K}$

IMPACT:

Elimination of this program would result in the following consequences:

Loss of a single point of contact to interface with RL SAS and other contractor Security organizations rosulting in inconsistent application of security requirements among contractors and a fragmented security program.

Loss of the Security Sensor Testing Program would result in a diminished detection capability of approximately $\mathbf{5 0 0}$ sensors, increasing the potential for loss of government property, classified matter or special nuclear material, and increased maintenance

costs.

Loss of a central point of contact in the Site Selection Task Group would result in the incressed potential for violations of DOE order requirements and the creation of security vulnerabilities during construction of land development activities.

Loss of coordination and oversight to the implementation of the RL Asset Protection Program which would result the ineffective application of order requirements, loss control over high, medium and low assets assigned to WHC 


\section{SAFEGUARDS AND SECURITY}

\section{Total Staffing Priorities - FY 1996 By Task}

\begin{tabular}{|c|c|c|c|c|}
\hline \multicolumn{5}{|l|}{ BUILDING BLOCKS FOR FY 1996} \\
\hline \multicolumn{5}{|l|}{ FY 1996 Building Blocks $(\$ 000)$} \\
\hline ORGANIZATIONAL WORK SCOPE DESCRIPTION & $\begin{array}{c}\text { ORG. FTE: } \\
\text { IN } \\
\text { WORKSCOPE }\end{array}$ & $\begin{array}{c}\text { SUPPORT } \\
\text { FTEs IN } \\
\text { WORKSCOPE }\end{array}$ & $\begin{array}{c}\text { FY } 1996 \\
\text { ORIGINAL } \\
\text { COST* }\end{array}$ & JUSTIFICATION OF SCOPE/IMPACT IF NOT FUNDED \\
\hline $\begin{array}{l}\text { 2F Lockemithe, Industrial Security (SLP) } \\
\text { Provide multi-contractor lockemith sonvices to Install, replace, and maintain locks, } \\
\text { koys, and access control systems on over } 1100 \text { government loased and owned } \\
\text { facilitios/buildings throughout the Hanford Sito. }\end{array}$ & $\begin{array}{c}.6(E X) \\
.6(N E) \\
2.5(B U)\end{array}$ & $\begin{array}{l}.1 \text { (EX) } \\
.1 \text { (BU) }\end{array}$ & $343.6 \mathrm{~K}$ & 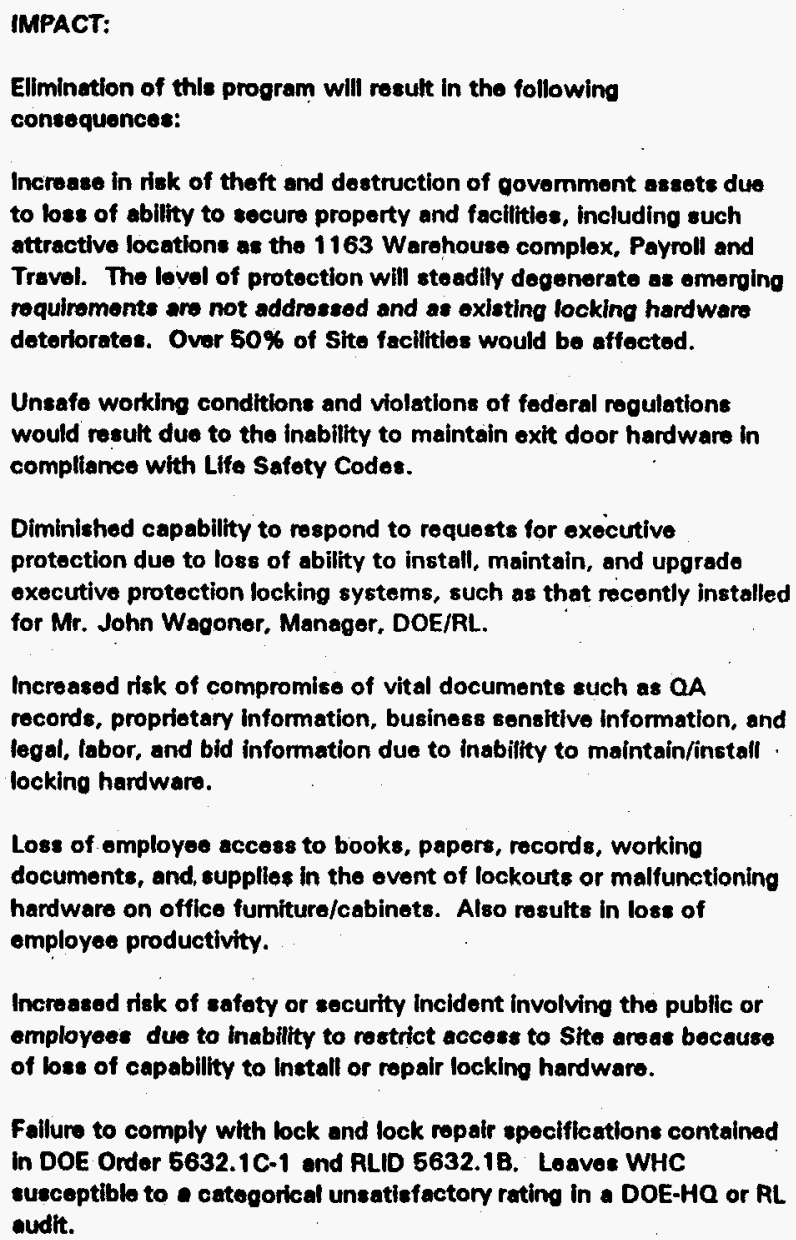 \\
\hline
\end{tabular}


SAFEGUARDS AND SECURITY

Total Staffing Priorities - FY 1996 By Task

\begin{tabular}{|c|c|c|c|c|}
\hline \multicolumn{5}{|l|}{ BUILDING BLOCKS FOR FY 1996} \\
\hline \multicolumn{5}{|l|}{ FY 1996 Bullding Blocks $(\$ 000)$} \\
\hline ORGANIZATIONAL WORK SCOPE DESCRIPTION & $\begin{array}{c}\text { ORQ. FTE: } \\
\text { NN } \\
\text { WORKSCOPE }\end{array}$ & $\begin{array}{l}\text { SUPPORT } \\
\text { FTE: IN } \\
\text { WORKSCOPE }\end{array}$ & $\begin{array}{l}\text { FY } 1898 \\
\text { ORIOINAL } \\
\text { COST' }\end{array}$ & JUSTIFICATION OF SCOPE/MPACT IF NOT FUNDED \\
\hline 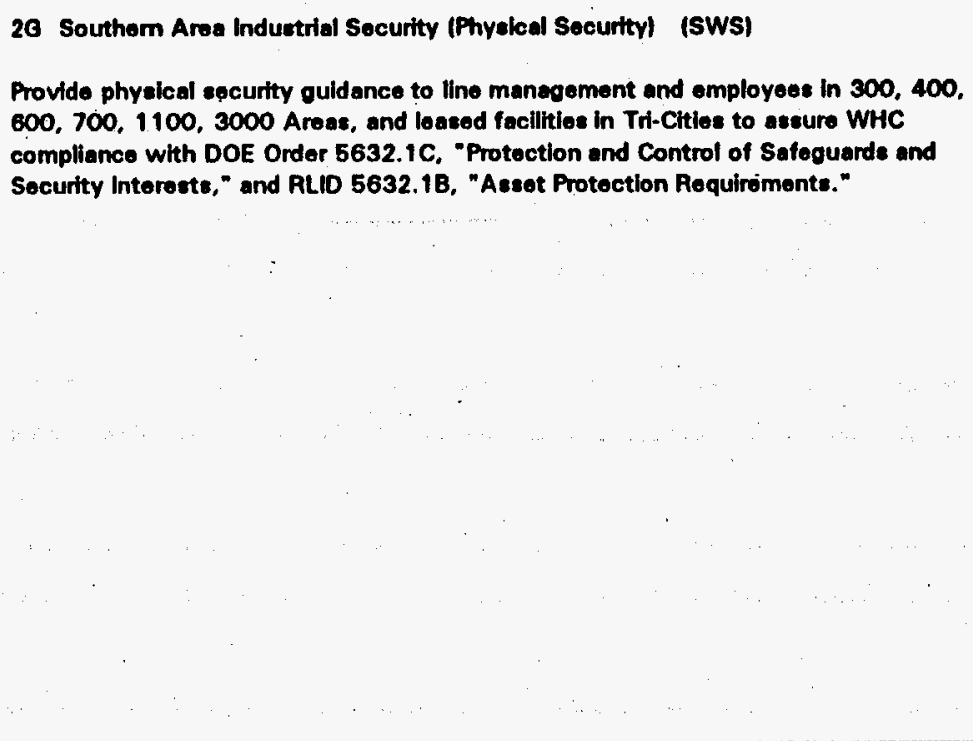 & $\begin{array}{l}4.3 \text { (EX) } \\
1.3 \text { (NE) }\end{array}$ & & $375.4 K$ & 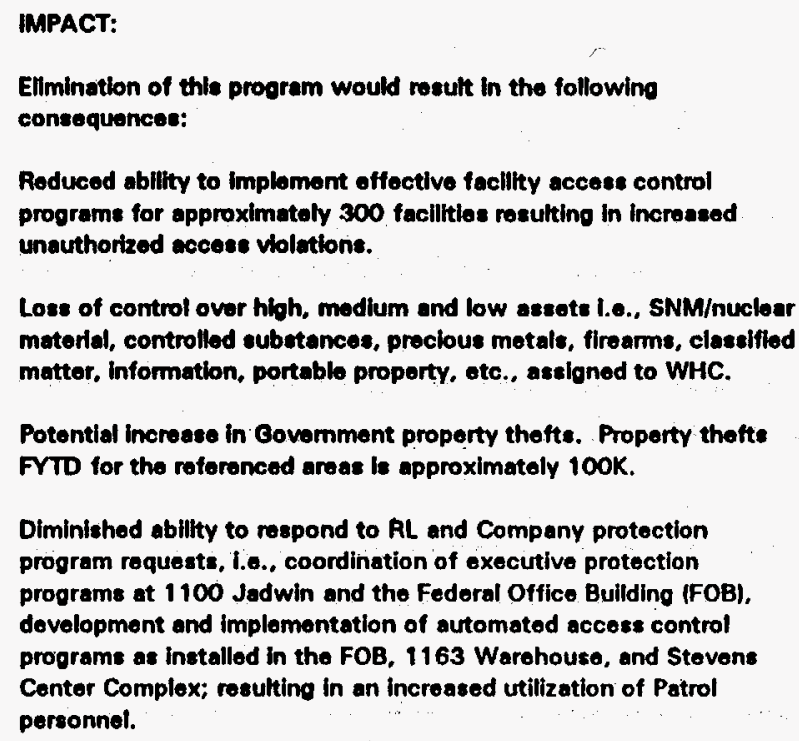 \\
\hline
\end{tabular}




\section{SAFEGUARDS AND SECURITY \\ Total Staffing Priorities - FY 1996 By Task}

\begin{tabular}{|c|c|c|c|c|}
\hline \multicolumn{5}{|l|}{ BUILDING BLOCKS FOR FY 1996} \\
\hline \multicolumn{5}{|l|}{ FY 1996 Building Blocks $(\$ 000)$} \\
\hline ORGANIZATIONAL WORK SCOPE DESCRIPTION & $\begin{array}{c}\text { ORG. FTE } \\
\text { IN } \\
\text { WORKSCOPE }\end{array}$ & $\begin{array}{c}\text { SUPPOAT } \\
\text { FTE: IN } \\
\text { WOAKSCOPE }\end{array}$ & $\begin{array}{l}\text { FY } 1996 \\
\text { ORIGINAL } \\
\text { COST" }\end{array}$ & JUȘTIFICATION OF SCOPE/IMPACT IF NOT FUNDED \\
\hline $\begin{array}{l}\text { 2H Northern Area Induatrial Security } \\
\text { Provides physical security guidance to line management and employees in } 200 E \text {, } \\
200 W .100 \text {, and } 600 \text { Aroas to include ostablishing policy for the throe Sito barricades. } \\
\text { Ensures WHC compliance with DOE Order } 5632.1 \mathrm{C} \text {, "Protection and Control of } \\
\text { Safeguards and Security Interests," and RLID 5632.1B, "Asset Protection } \\
\text { Requirements." }\end{array}$ & $\begin{array}{l}1.0 \text { (EX) } \\
.1 \text { (NE) }\end{array}$ & & $80.8 \mathrm{~K}$ & 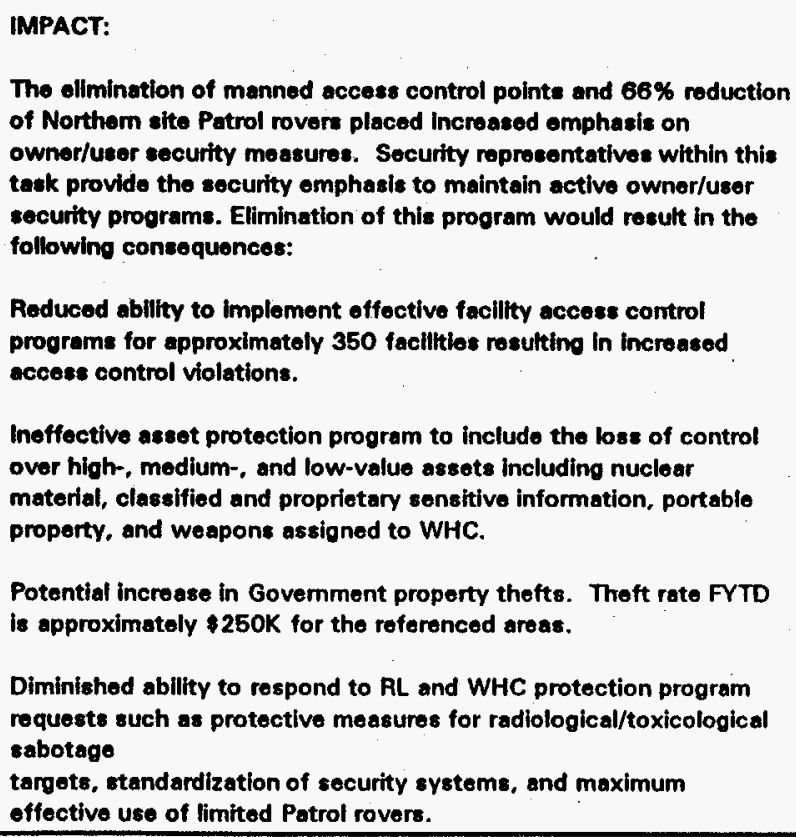 \\
\hline $\begin{array}{l}21 \text { Site Safeguards and Security Plans } \\
\text { (SWS) } \\
\text { To update the Hantord SSSP for RL and to provide the necessary review cycle to } \\
\text { onsure DOE approval as required by DOE Orders. The SSSP dofines the SAS Site and } \\
\text { Facility wide functions and olements in the S\&S Management Report (Part I). It } \\
\text { provides facility VARs (Part III. }\end{array}$ & $\begin{array}{l}.5 \text { (EX) } \\
.2 \text { (NE) }\end{array}$ & & $44.3 \mathrm{~K}$ & $\begin{array}{l}\text { IMPACT: } \\
\text { This activity is required to ensure a baseline plan for the status of } \\
\text { the S\&S system. Defines mossures required to maintain low } \\
\text { consequence/risk and defines programe upgrade plans. }\end{array}$ \\
\hline
\end{tabular}


SAFEGUARDS AND SECURITY

Total Staffing Priorities - FY 1996 By Task

\begin{tabular}{|c|c|c|c|c|}
\hline \multicolumn{5}{|l|}{ BUILDING BLOCKS FOR FY 1996} \\
\hline \multicolumn{5}{|l|}{ FY 1996 Bullding Blocke $(8000)$} \\
\hline ORGANIZATIONAL WORK SCOPE DESCRIPTION & $\begin{array}{c}\text { ORG. FTE } \\
\text { IN } \\
\text { WORKSCOPE }\end{array}$ & $\begin{array}{c}\text { SUPPORT } \\
\text { FTE: IN } \\
\text { WORKSCOPE }\end{array}$ & $\begin{array}{l}\text { FY } 1998 \\
\text { ORIGINAL } \\
\text { COST }\end{array}$ & JUSTIFICATION OF SCOPE/IMPACT IF NOT FUNDED \\
\hline 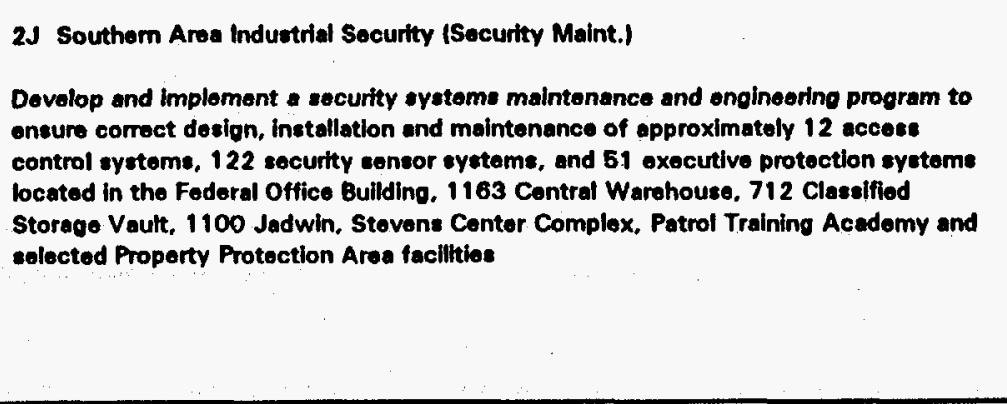 & $\begin{array}{l}1.0(E X) \\
.5(N E) \\
2.0(B U)\end{array}$ & .2 (EX) & $252.6 \mathrm{~K}$ & 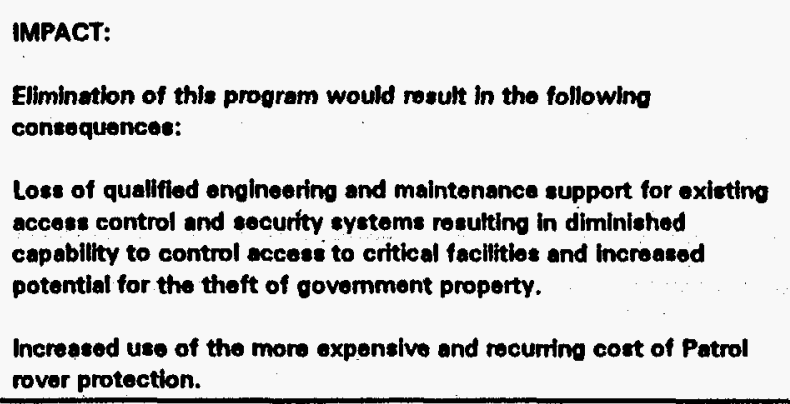 \\
\hline $\begin{array}{l}\text { 2K Northein Area Industrial Security Engineoring (SWS) } \\
\text { This is a prorated assessment of .7 (from the direct funded engineering and } \\
\text { maintenance) to provide nonprogram specific security system } \\
\text { engineering/maintenance and staff support for facilities in the 200E, 200W, 100, and } \\
600 \text { aress that do NOT store category I or II SNM. Such facilities include Tank Farms. } \\
\text { Solid Waste. B-Plant. ond PUREX. }\end{array}$ & $\begin{array}{l}.4 \text { (EX) } \\
.3 \text { (NE) }\end{array}$ & & $47.9 \mathrm{~K}$ & 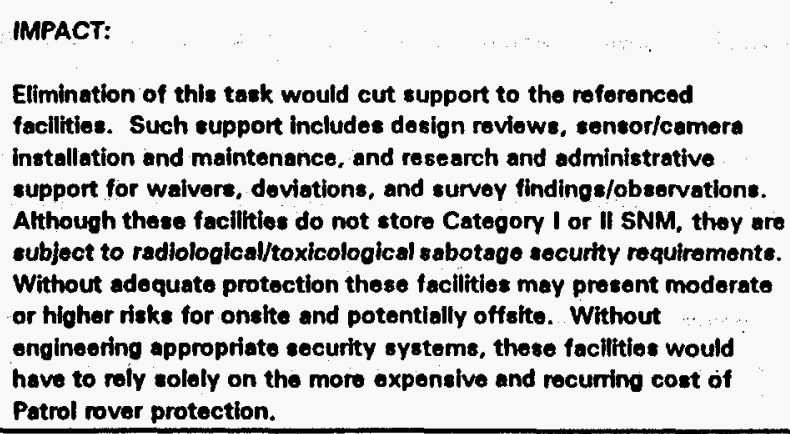 \\
\hline 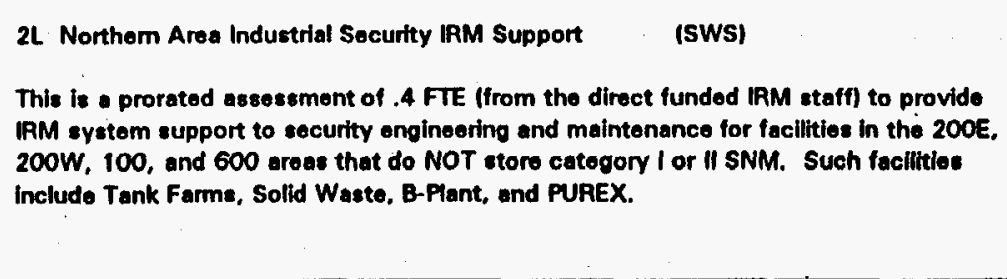 & & .4 (EX) & $26.4 K$ & 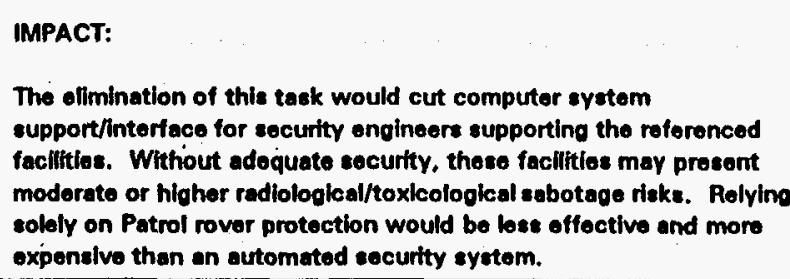 \\
\hline
\end{tabular}




\section{SAFEGUARDS AND SECURITY \\ Total Staffing Priorities - FY 1996 By Task}

\begin{tabular}{|c|c|c|c|c|}
\hline \multicolumn{5}{|l|}{ BUILDING BLOCKS FOR FY 1996} \\
\hline \multicolumn{5}{|l|}{ FY 1996 Bullding Blocks $(1000)$} \\
\hline ORGANIZATIONAL WORK SCOPE DESCRIPTION & $\begin{array}{l}\text { ORO. FTE: } \\
\text { IN } \\
\text { WORKSCOPE }\end{array}$ & $\begin{array}{l}\text { SUPPORT } \\
\text { FTEs IN } \\
\text { WORKSCOPE }\end{array}$ & $\begin{array}{l}\text { FY } 1996 \\
\text { ORIGINAL } \\
\text { COST" }\end{array}$ & JUSTIFICATION OF SCOPE/IMPACT IF NOT FUNDED \\
\hline 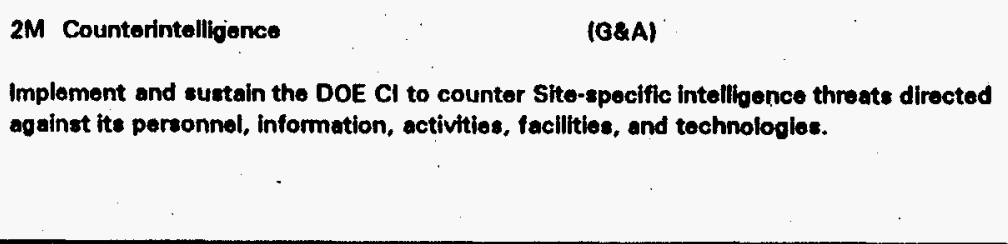 & $\begin{array}{l}1.2 \text { (EX) } \\
.2 \text { (NE) }\end{array}$ & & $99.2 \mathrm{~K}$ & $\begin{array}{l}\text { IMPACT: } \\
\text { Exposure of DOE personnel to attempte from forelgn activitios } \\
\text { deslgned to colloct national securtty claseifiod and sonsitive } \\
\text { Information. Fines and assesements for not complying with the } \\
\text { Atomic Eneroy Act of } 1954 \text { and Reporting Hostile Contacts and } \\
\text { Securty Awareness (NSDD 197). }\end{array}$ \\
\hline
\end{tabular}


SAFEGUARDS AND SECURITY

Total Staffing Priorities - FY 1996 By. Task

\begin{tabular}{|c|c|c|c|c|}
\hline \multicolumn{5}{|l|}{ BUILDING BLOCKS FOR FY 1996} \\
\hline \multicolumn{5}{|l|}{ FY 1996 Bullding Blocks $(\$ 000)$} \\
\hline ORGANIZATIONAL WORK SCOPE DESCRIPTION & $\begin{array}{c}\text { ORO. FTE } \\
\text { IN } \\
\text { WORKSCOPE }\end{array}$ & $\begin{array}{c}\text { SUPPORT } \\
\text { FTE IN } \\
\text { WORKSCOPE }\end{array}$ & $\begin{array}{c}\text { FY } 1996 \\
\text { ORIGINAL } \\
\text { COST. }\end{array}$ & JUSTIFICATION OF SCOPE/MPACT IF NOT FUNDED \\
\hline 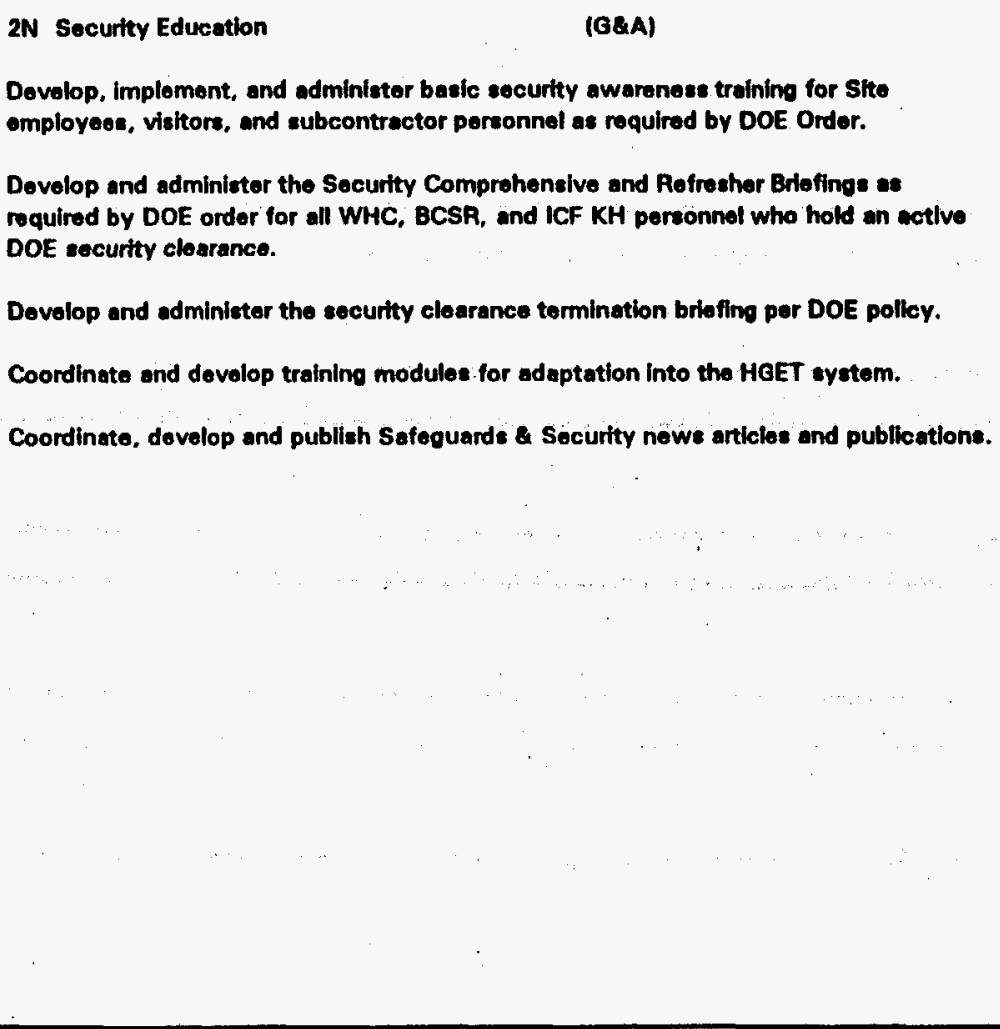 & 2.0 (EX) & & $150.7 \mathrm{~K}$ & 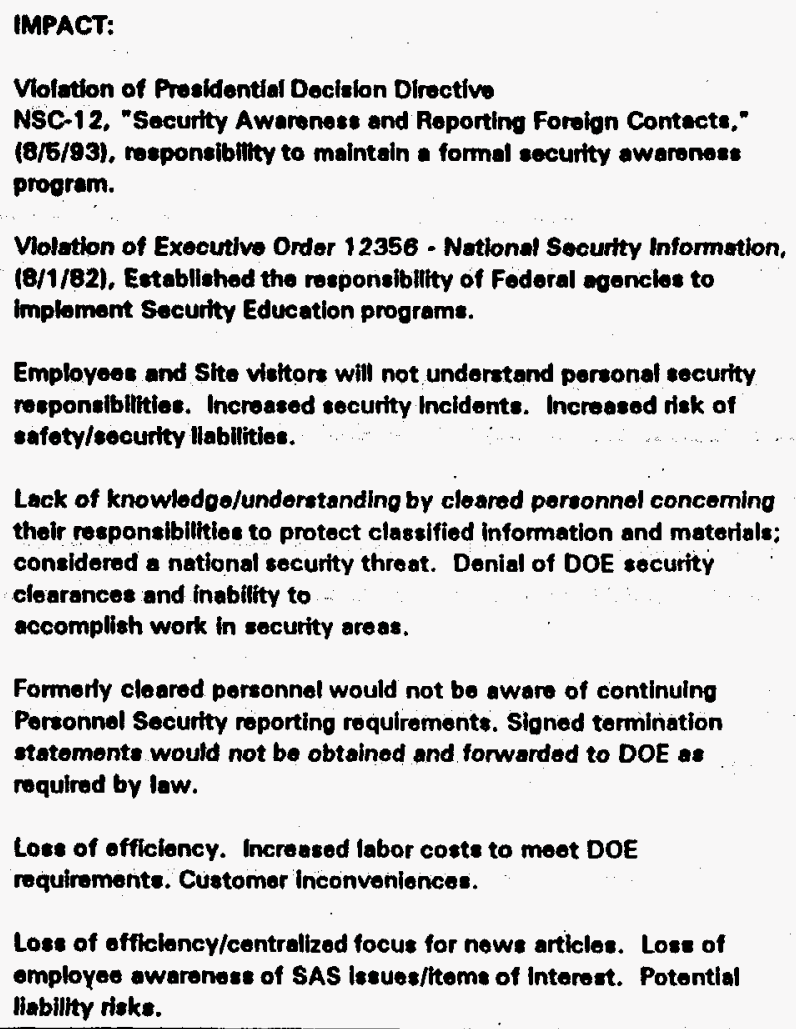 \\
\hline
\end{tabular}




\section{SAFEGUARDS AND SECURITY \\ Total Staffing Priorities - FY 1996 By Task}

\begin{tabular}{|c|c|c|c|c|}
\hline \multicolumn{5}{|l|}{ BUILDING BLOCKS FÓR FY 1996} \\
\hline \multicolumn{5}{|l|}{ FY 1996 Building Blocks ( $\$ 000)$} \\
\hline ORGANIZATIONAL WORK SCOPE DESCRIPTION & $\begin{array}{c}\text { ORQ. FTE: } \\
\text { iN } \\
\text { WORKSCOPE }\end{array}$ & $\begin{array}{l}\text { SUPPORT } \\
\text { FTES IN } \\
\text { WORKSCOPE }\end{array}$ & $\begin{array}{l}\text { FY } 1996 \\
\text { ORIGINAL } \\
\text { COST* }\end{array}$ & JUSTIFICATION OF SCOPEIIMPACT IF NOT FUNDED \\
\hline 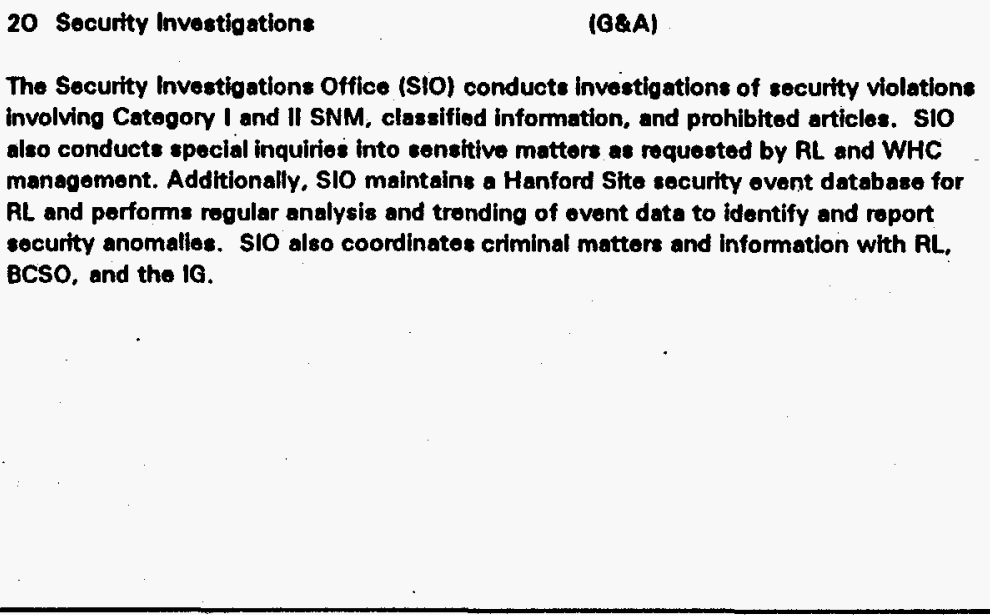 & $\begin{array}{l}2.0 \text { (EX) } \\
.6 \text { (NE) }\end{array}$ & & $170.2 \mathrm{~K}$ & $\begin{array}{l}\text { IMPACT: } \\
\text { Elimination of this task would result in the following coneequences: } \\
\text { WHC would be in volation of FAR Chapter 1. Subchapter } 0 \text { - } \\
\text { Contract Management, Part } 45.504 \text { - Contractor Liability, which } \\
\text { requires the contractor to Investigate and report all cases of loss, } \\
\text { damage or destruction of government property. } \\
\text { Noncompliance to DOE Orders to investigate security incidents. } \\
\text { Loss of capability to maintain a security incident database and trend } \\
\text { thefte and security violations. } \\
\text { Reduced capability to determine root causes for security incidents } \\
\text { and initiate corrective actions and procedural changes/clarifications. } \\
\text { Limit our ability to administer the Security infraction program. } \\
\text { Loss of Dignitary Protection and law enforcement interface. }\end{array}$ \\
\hline $\begin{array}{l}\text { 2P Unclassified Computer Security } \\
\text { (G\&A) } \\
\text { Develop, Implement, and sustain the DOE Unclassified Computer Security Program. } \\
\text { This program encompasses the computers, data, software and networks used to } \\
\text { process DOE and WHC information. }\end{array}$ & $\begin{array}{l}2.2 \text { (EX) } \\
.2 \text { (NE) }\end{array}$ & $\cdot$ & $170.2 \mathrm{~K}$ & $\begin{array}{l}\text { IMPACT: } \\
\text { LOss of control over information protected by public law (ECI, AT, } \\
\text { Privacy, UCNI, otc). Fines and assessments for not providing the } \\
\text { means to enact provisions of the Computer Socurity Act of } 1987 \text {. } \\
\text { the Management of Foderal Information Resources (OMB Cir } \\
\text { A-130), and the National Policy on Telecommunications and } \\
\text { Automated information Systems Security. }\end{array}$ \\
\hline
\end{tabular}


SAFEGUARDS AND SECURITY

Total Staffing Priorities - FY 1996 By Task

\begin{tabular}{|c|c|c|c|c|}
\hline \multicolumn{5}{|l|}{ BUILDING BLOCKS FOR FY 1996} \\
\hline \multicolumn{5}{|l|}{ FY 1996 Building Blocke $(1000)$} \\
\hline ORGANIZATIONAL WORK SCOPE DESCRIPTION & $\begin{array}{l}\text { ORQ. FTE: } \\
\text { IN } \\
\text { WORKSCOPE }\end{array}$ & $\begin{array}{l}\text { SUPPORT } \\
\text { FTEE IN } \\
\text { WORKSCOPE }\end{array}$ & $\begin{array}{c}\text { FY } 1996 \\
\text { ORIGINAL } \\
\text { COST" }\end{array}$ & JUSTIFICATION OF SCOPE/MPACT IF NOT FUNDED \\
\hline 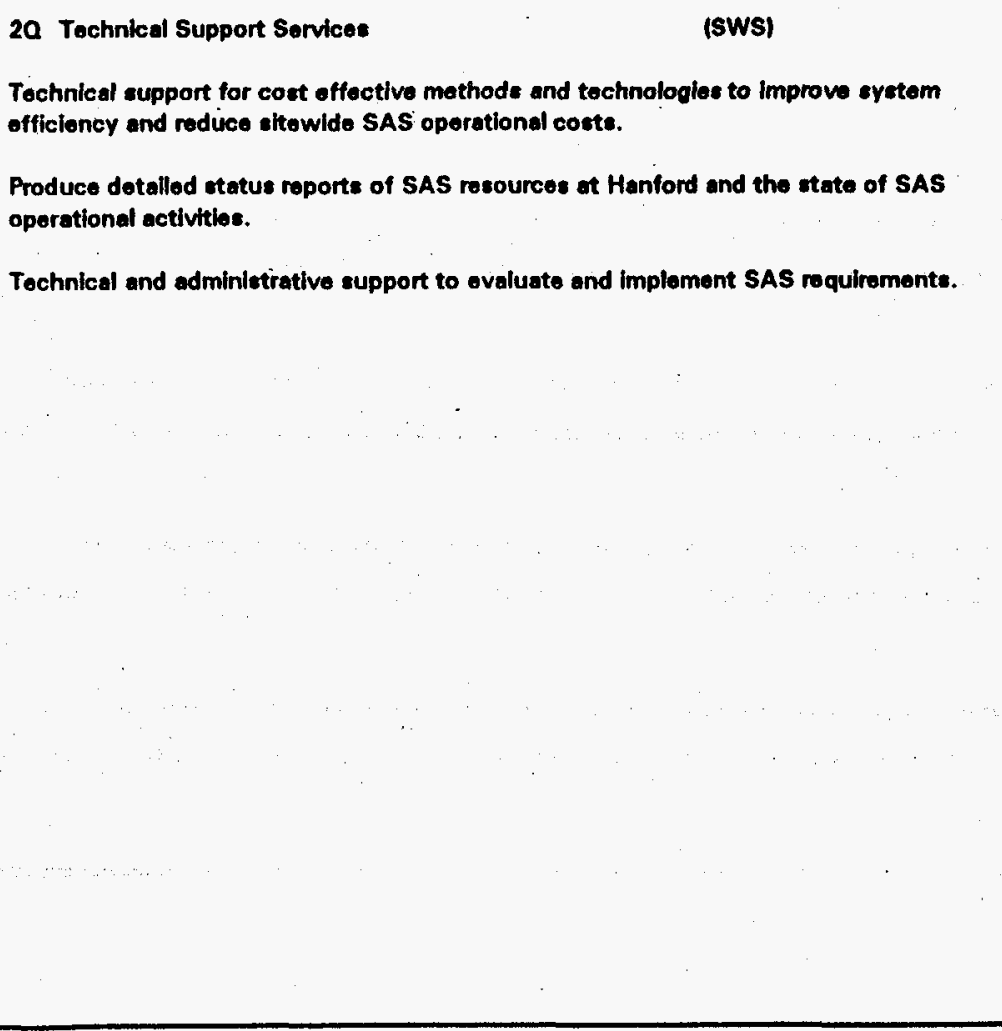 & $3.0(E X)$ & & $275.5 \mathrm{~K}$ & 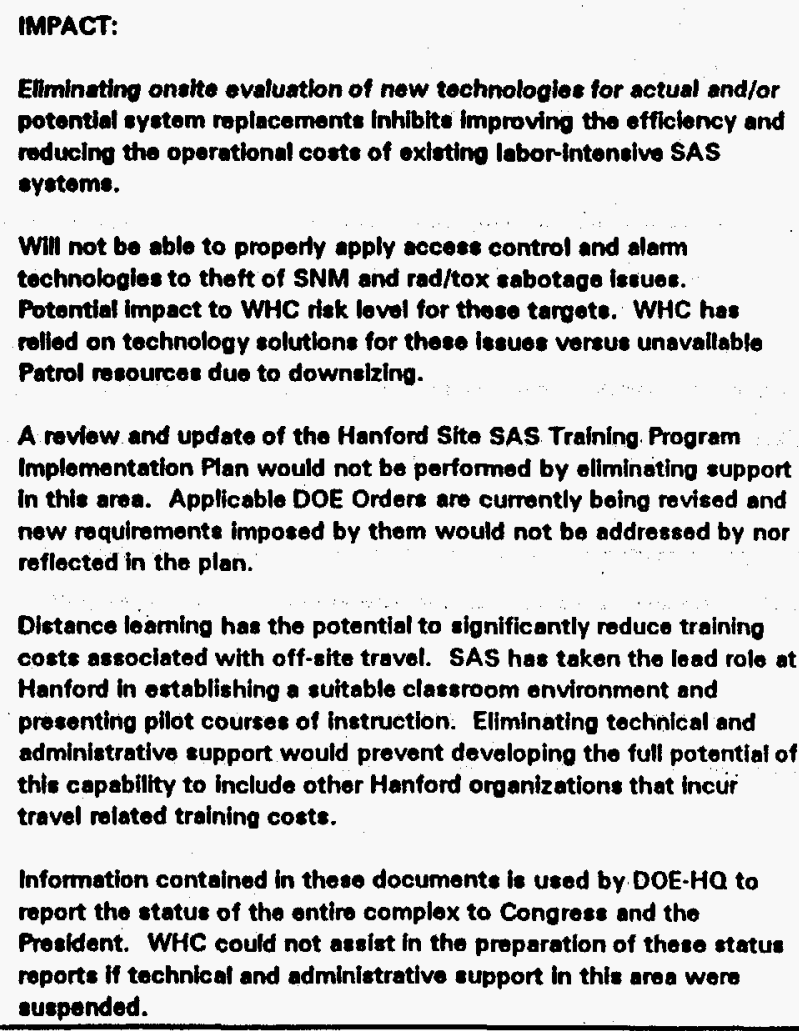 \\
\hline 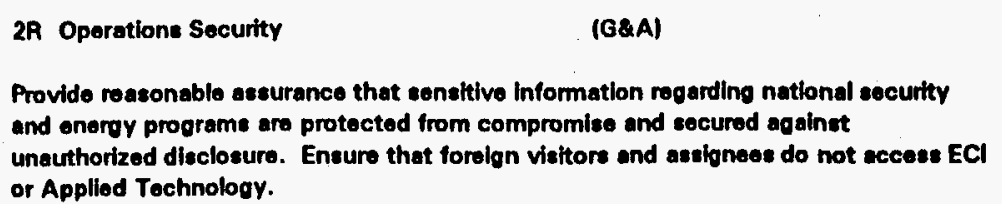 & $\begin{array}{l}1.2(\mathrm{EX}) \\
.2(\mathrm{NE})\end{array}$ & & $99.2 \mathrm{~K}$ & 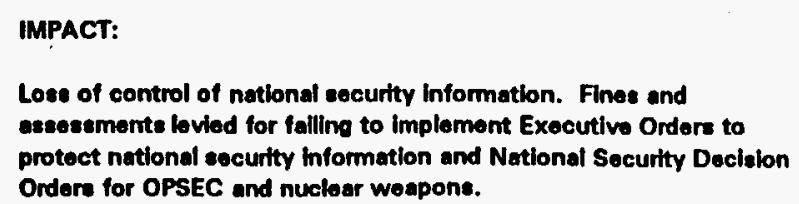 \\
\hline
\end{tabular}




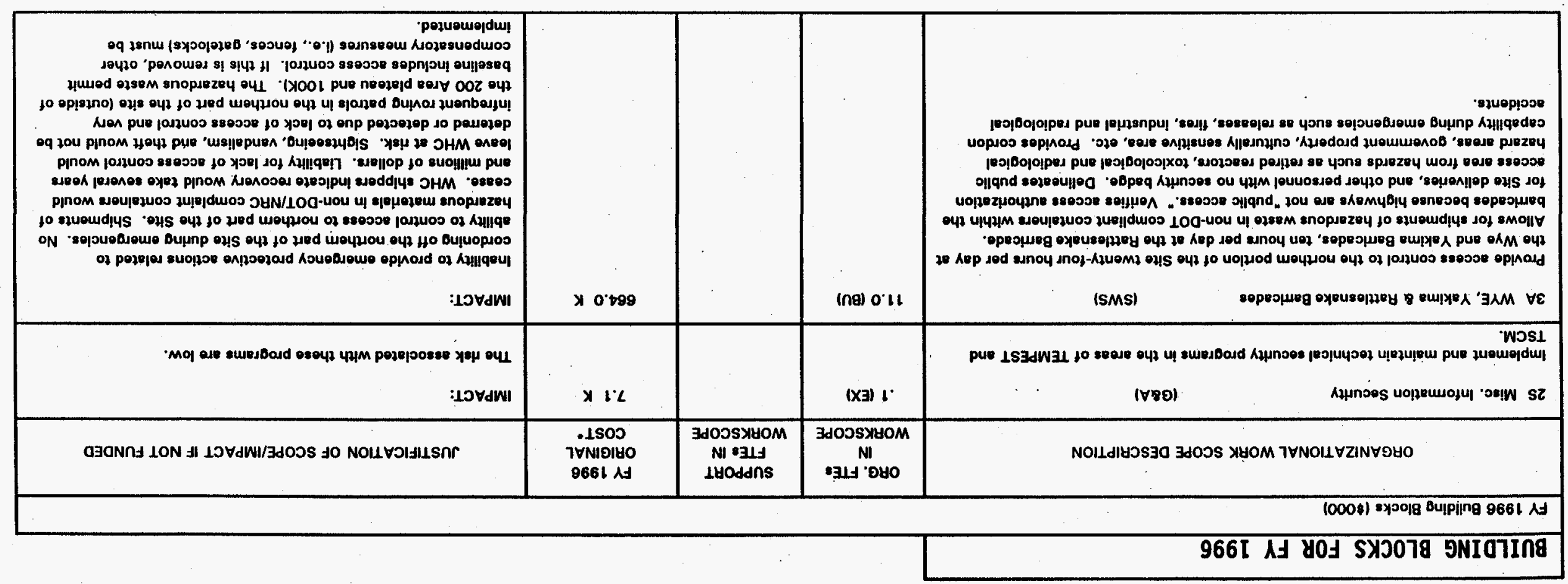

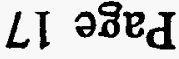

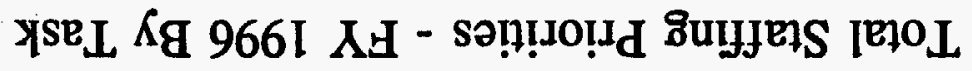

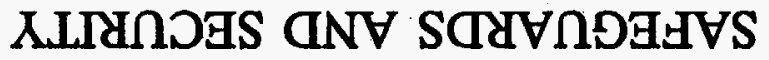


SAFEGUARDS AND SECURITY

Total Staffing Priorities - FY 1996 By Task

\begin{tabular}{|c|c|c|c|c|}
\hline \multicolumn{5}{|l|}{ BUILDING BLOCKS FOR FY 1996} \\
\hline \multicolumn{5}{|l|}{ FY 1996 Bullding Blocks $(\$ 000)$} \\
\hline ORGANIZATIONAL WORK SCOPE DESCRIPTION & $\begin{array}{c}\text { ORO. FTE } \\
\text { IN } \\
\text { WORKSCOPE }\end{array}$ & $\begin{array}{l}\text { SUPPORT } \\
\text { FTE: IN } \\
\text { WOAKSCOPE }\end{array}$ & $\begin{array}{c}\text { FY } 1988 \\
\text { ORIONAL } \\
\text { COST: }\end{array}$ & JUSTIFICATION OF SCOPE/IMPACT IF NOT FUNDED \\
\hline 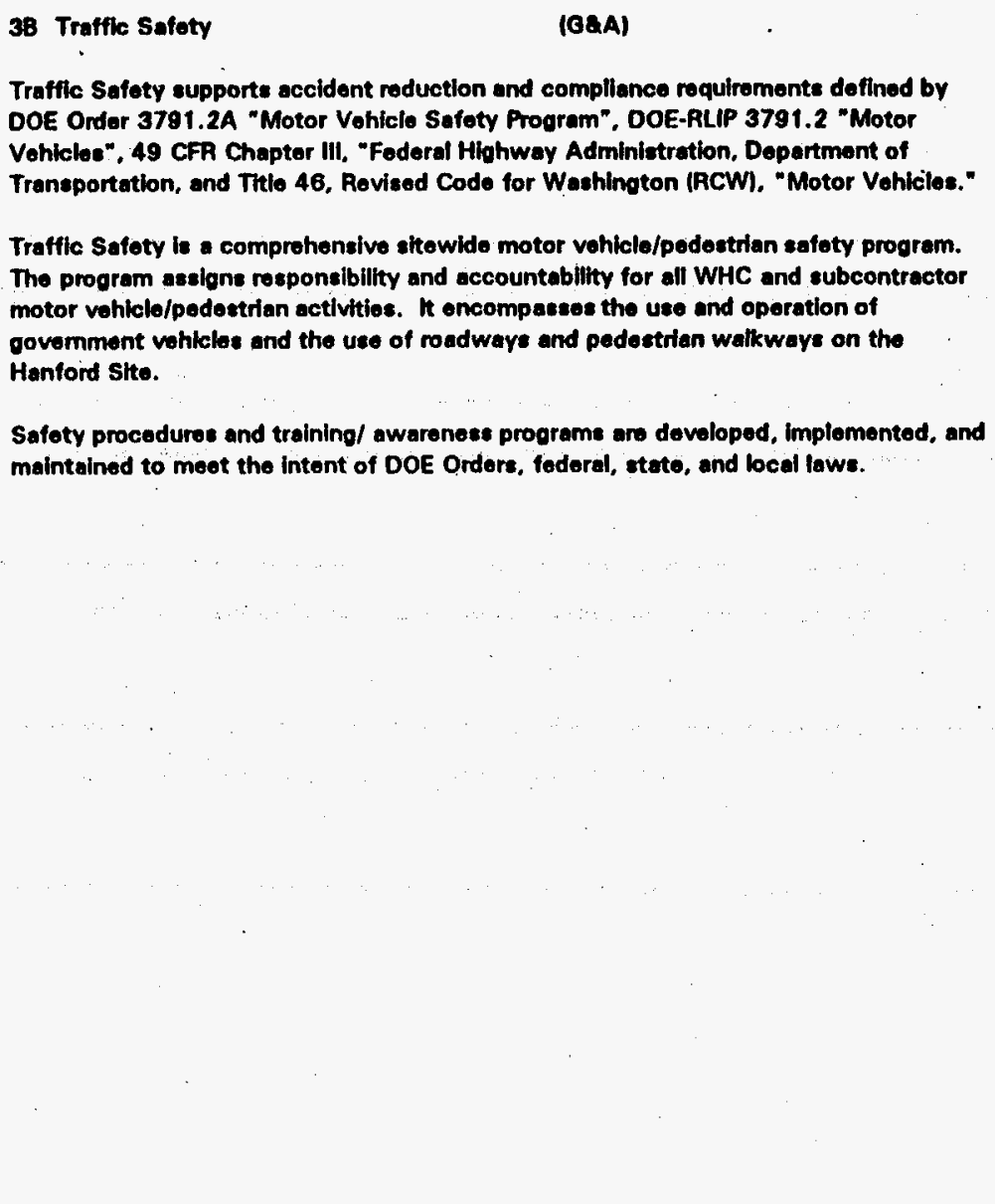 & 2.0 (EX) & & $165.0 \mathrm{~K}$ & 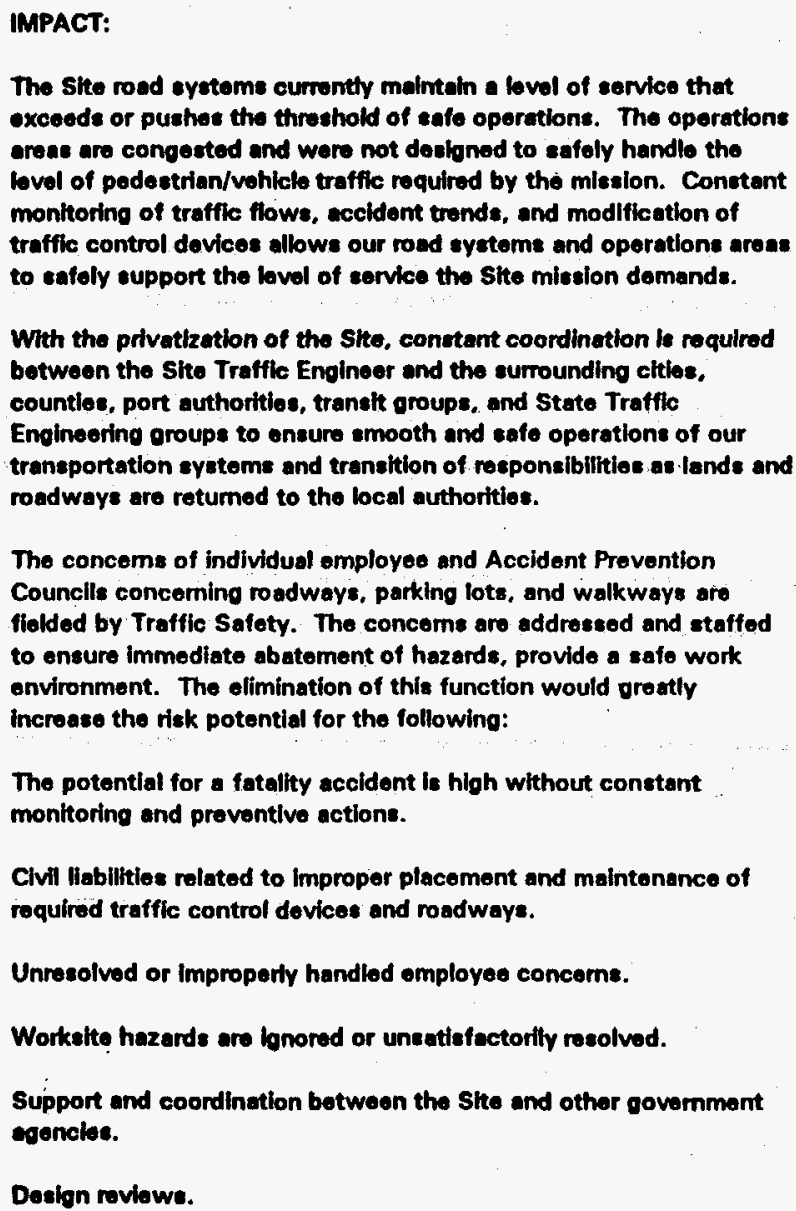 \\
\hline
\end{tabular}




\section{SAFEGUARDS AND SECURITY \\ Total Staffing Priorities - FY 1996 By Task}

\section{BUILDING BLOCKS FOR FY 1996}

\section{FY 1996 Building Blocks (1000)}

\begin{tabular}{|c|c|c|c|c|}
\hline ORGANIZATIONAL WORK SCOPE DESCRIPTION & $\begin{array}{l}\text { ORO. FTE: } \\
\text { IN } \\
\text { WORKSCOPE }\end{array}$ & $\begin{array}{l}\text { SUPPORT } \\
\text { FTEE IN } \\
\text { WORKSCOPE }\end{array}$ & $\begin{array}{l}\text { FY } 1996 \\
\text { ORIGINAL } \\
\text { COST* }\end{array}$ & JUSTIFICATION OF SCOPE/MPACT IF NOT FUNDED \\
\hline $\begin{array}{l}\text { O Managoment administration } \\
\text { This task provides dopartment overhead conte for the SAS organlzation to support } \\
\text { direct fundod exempt, nonexempt, and bargaining unit personnel. The support } \\
\text { includes building adminietration, porformance measurements, vehicle and equipment } \\
\text { management, policy and procedure dovelopmerit, training, secretarial aupport, and } \\
\text { budget programming/planning. }\end{array}$ & $\begin{array}{l}5.6 \text { (EX) } \\
1.5 \text { (NE) } \\
.5 \text { (BU) }\end{array}$ & $.6(E X)$ & $627.7 \mathrm{~K}$ & $\begin{array}{l}\text { IMPACT: } \\
\text { Ellminotion of this task would cut eseential overhead support for } \\
\text { FFP. Spent Nucloar Fuel. Transition projects, intermational } \\
\text { agreoments, and FFIF. Funding would be olliminated for training. } \\
\text { technical exchanges, and administration. SAS would be unable to } \\
\text { respond to RL requests for information performance ratings, SMS } \\
\text { reporting, corrective action plans, reviows for compliance, support } \\
\text { for DOE workshops and overall management of critical security } \\
\text { programs. }\end{array}$ \\
\hline $\begin{array}{l}\text { o Facility Property Administration } \\
\text { Building maintenance, telophone, emergency ovacuation, administration access } \\
\text { control. }\end{array}$ & $\begin{array}{l}1.0(E X) \\
.3 \text { (NE) }\end{array}$ & & $152.6 \mathrm{~K}$ & $\begin{array}{l}\text { IMPACT: } \\
\text { Single coordination point (point of contact) will be eliminated. } \\
\text { Potential impacts to OSHA standards regarding facilities' inability to } \\
\text { perform administrative access control tesks }\end{array}$ \\
\hline $\begin{array}{l}0 \text { Customer Interface \& Briefings } \\
\text { Prepare briefing and special request information for customer reporting. }\end{array}$ & $\begin{array}{l}1.0 \text { (EX) } \\
1.2 \text { (NE) }\end{array}$ & & $121.7 \mathrm{~K}$ & $\begin{array}{l}\text { IMPACT: } \\
\text { Communication and the ability to support customer request and } \\
\text { status reporting would be eliminated. }\end{array}$ \\
\hline $\begin{array}{l}0 \text { Training and Professional Dovelopment } \\
\text { Time spent in general Site training, also includes tuition and oducational } \\
\text { reimbursements. }\end{array}$ & $\begin{array}{l}.4 \text { (EX) } \\
1.3 \text { (NE) } \\
.3 \text { (BU) }\end{array}$ & $.7(\mathrm{BU})$ & $498.8 \mathrm{~K}$ & $\begin{array}{l}\text { IMPACT: } \\
\text { General Site training and educational reimbursements would be } \\
\text { elliminated. This is contrary to the provisions of Public Law 93-438, } \\
\text { The Energy Reorganization Act of } 1974 \text {, which authorizes DOE to } \\
\text { support employee oducational programs in order to ensure an } \\
\text { adequate supply of monpower. Personnel would not maint ain } \\
\text { current training lovel required. professional development initiative } \\
\text { would not be supported. }\end{array}$ \\
\hline $\begin{array}{l}\text { O Financial Preparation \& Briefings } \\
\text { Prepare program plan, basoline managoment and control. Propare and lesue monthly } \\
\text { managoment roports and prosentations. }\end{array}$ & $\begin{array}{l}1.0 \text { (EX) } \\
1.0 \text { (NE) }\end{array}$ & & $111.9 \mathrm{~K}$ & $\begin{array}{l}\text { IMPACT: } \\
\text { Basoline documents, planning and reporting will not be dono. }\end{array}$ \\
\hline
\end{tabular}


SAFEGUARDS AND SECURITY

Total Staffing Priorities - FY 1996 By Task

\begin{tabular}{|c|c|c|c|c|}
\hline \multicolumn{5}{|l|}{ BUILDING BLOCKS FOR FY 1996} \\
\hline \multicolumn{5}{|l|}{ FY 1998 Building Blocks $(1000)$} \\
\hline ORGANIZATIONAL WORK SCOPE DESCRIPTION & $\begin{array}{l}\text { OAG. FTE: } \\
\text { IN } \\
\text { WORKSCOPE }\end{array}$ & $\begin{array}{l}\text { SUPPORT } \\
\text { FTEs IN } \\
\text { WORKSCOPE }\end{array}$ & $\begin{array}{l}\text { FY } 1986 \\
\text { ORIGINAL } \\
\text { COST: }\end{array}$ & JUSTIFICATION OF SCOPE/MPACT IF NOT FUNDED \\
\hline $\begin{array}{l}\text { O Employee Concerns } \\
\text { Deal with omployee concern iseues for } 300+\text { organizatione. Much of the work is } \\
\text { preemptive in nature to clear up iseues as oarly ae possible. }\end{array}$ & $1.0(E X)$ & & $72.8 \mathrm{~K}$ & $\begin{array}{l}\text { IMPACT: } \\
\text { Employee conceme would not be dealt with at the department loval. } \\
\text { They would muahroom upward. }\end{array}$ \\
\hline $\begin{array}{l}\text { - Equlpment Procurement, Contracte and Accountability } \\
\text { Order receive and track equipment procured for SAS. }\end{array}$ & .2 (NE) & .6 (EX) & $557.0 \mathrm{~K}$ & $\begin{array}{l}\text { IMPACT: } \\
\text { No order or tracking of material and equipment activty. Such as } \\
\text { badging. Lockemith and training otc. }\end{array}$ \\
\hline $\begin{array}{l}\text { O WHC Programs - C-170 } \\
\text { Savings Thru Sharing } \\
\text { Roengineering }\end{array}$ & $\begin{array}{l}.3 \text { (EX) } \\
.3 \text { (NE) }\end{array}$ & . & $28.0 \mathrm{~K}$ & $\begin{array}{l}\text { IMPACT: } \\
\text { Initiatives can not be supported. }\end{array}$ \\
\hline 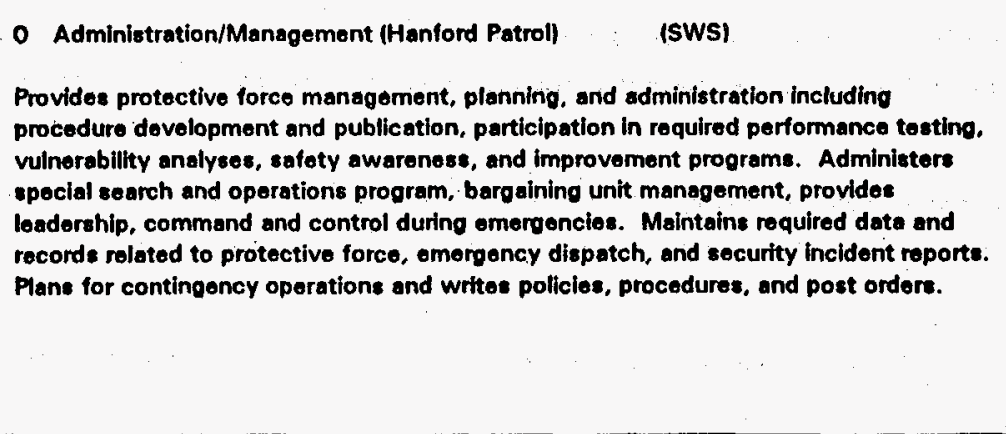 & $\begin{array}{l}6.0 \text { (EX) } \\
1.4 \text { (NE) }\end{array}$ & & $512.0 \mathrm{~K}$ & $\begin{array}{l}\text { IMPACT: } \\
\text { Hanford has the loanest protective force of any major Site. } \\
\text { Reductions in management and administration have been wholesalo } \\
\text { over the past four yeare. Any further reductions will result in } \\
\text { inadequate protective force performance both in terms of routine } \\
\text { and emergency dutios. DOE Orders require "adequate" lovels of } \\
\text { administration, aupenvision and management. Current levels are } \\
\text { barely so. RL has stated that further protectivo force roductione are } \\
\text { not acceptable, today's posture is minimum. Patrol would be } \\
\text { unablo to maintain or comply with required Hanford emergoncy } \\
\text { plans. An armed protective force requires active managoment for } \\
\text { safety and conduct of operations. }\end{array}$ \\
\hline
\end{tabular}

